Felipe de Sousa Esteves

\title{
Competências Globais de Liderança, Capacidades Dinâmicas e Desempenho em Equipes de Projeto
}

Tese de Doutorado

Tese apresentada como requisito parcial para obtenção do grau de Doutor pelo Programa de Pós-graduação em Administração de Empresas do Departamento de Administração da PUC-Rio.

Orientadora: Prof ${ }^{a}$. Flávia de Souza Costa Neves

Cavazotte 
Felipe de Sousa Esteves

Competências Globais de Liderança, Capacidades Dinâmicas e Desempenho em

Equipes de Projeto

Tese de Doutorado

Tese apresentada como requisito parcial para obtenção do grau de Doutor pelo Programa de Pósgraduação em Administração de Empresas. Aprovada pela Comissão Julgadora abaixo.

Prof . Flávia de Souza Costa Neves Cavazotte

Orientadora

Departamento de Administração - PUC-Rio

Prof ${ }^{a}$. Ana Heloísa da Costa Lemos

Departamento de Administração - PUC-Rio

Prof Jorge Manoel Teixeira Carneiro

EAESP-FGV

Profa. Paula Castro Pires de Souza Chimenti

COPPEAD-UFRJ

Prof. Valter de Assis Moreno Jr. IbMEC

Rio de Janeiro, 5 de maio de 2020 
Todos os direitos reservados. É proibida a reprodução total ou parcial do trabalho sem a autorização da universidade, da autora e do orientador.

\section{Felipe de Sousa Esteves}

Graduou-se em Administração de Empresas pela Pontifícia Universidade Católica do Rio de Janeiro em 2012 e concluiu o Mestrado Acadêmico em Administração de Empresas pela Pontifícia Universidade Católica do Rio de Janeiro em 2015.

Ficha Catalográfica

Esteves, Felipe de Sousa

Competências globais de liderança, capacidades dinâmicas e desempenho em equipes de projeto / Felipe de Sousa Esteves ; orientadora: Flávia de Souza Costa Neves Cavazotte. - 2020.

125 f. : il. color. ; $30 \mathrm{~cm}$

Tese (doutorado)-Pontifícia Universidade Católica do Rio de Janeiro, Departamento de Administração, 2020.

Inclui bibliografia

1. Administração - Teses. 2. Liderança transformacional. 3. Liderança transacional. 4. Liderança instrumental. 5. Liderança empoderadora. 6. Capacidades dinâmicas. I. Cavazotte, Flávia de Souza Costa Neves. II. Pontifícia Universidade Católica do Rio de Janeiro. Departamento de Administração. III. Título. 
Aos meus pais Fernando e Sandra, com infinito amor. 


\section{Agradecimentos}

Agradeço a Deus e a minha família, especialmente aos meus pais, por estarem todos esses anos ao meu lado, me incentivando e ajudando a me tornar uma pessoa melhor. Obrigado pela dedicação e por não desistirem de mim. Amo vocês.

À minha orientadora, Professora Flávia de Souza Costa Neves Cavazotte, por servir de inspiração, tanto acadêmica quanto profissional. Obrigado por aceitar esse desafio, por me incentivar e pela dedicação, orientação e apoio, fundamentais para a construção e conclusão desta tese.

Às Professoras Ana Heloísa da Costa Lemos e Paula Chimenti e ao Professor Jorge Carneiro, que compuseram a banca examinadora, pelas contribuições para o desenvolvimento desta tese. Em particular, agradeço ao Professor Valter de Assis Moreno Jr., pelos ensinamentos e pelas valiosas contribuições, fundamentais para esta tese.

A todos os meus outros professores, aos funcionários do IAG, secretaria de pósgraduação e agradeço especialmente à Teresa Campos pelo carinho e dedicação.

À PUC-Rio, pelos auxílios concedidos, sem os quais este trabalho não poderia ser realizado.

Ao amigo Rafael Clemente, a quem tenho grande admiração, pelos incentivos dados a mim e pela grande ajuda com a coleta de dados desta tese.

Ao amigo Oswald de Souza pelo carinho, amizade e por ser um grande exemplo para mim.

Agradeço aos amigos Armando Mariante Maria Helena Braule Pinto, pelo enorme carinho, exemplo e incentivos dados a mim.

Aos meus enfermeiros, especialmente ao Francisco Campos, por me ajudarem todos os dias ao longo dessa jornada.

O presente trabalho foi realizado com apoio da Coordenação de Aperfeiçoamento de Pessoal de Nível Superior - Brasil (CAPES) - Código de Financiamento 001 


\section{Resumo}

Esteves; Felipe de Sousa. Cavazzotte, Flávia de Souza Costa Neves. Competências Globais de Liderança, Capacidades Dinâmicas e Desempenho em Equipes de Projeto. Rio de Janeiro, 2020. 125 p. Tese de Doutorado - Departamento de Administração, Pontifícia Universidade Católica do Rio de Janeiro.

Esta tese propõe um modelo teórico que integra e associa as perspectivas transformacional, transacional (BASS, 1985), instrumental (ANTONAKIS \& HOUSE, 2014) e empoderadora (PEARCE \& SIMS, 2002) da liderança com a geração de capacidades dinâmicas e obtenção de vantagem competitiva em equipes de projeto. Com base em teorias de motivação e sua articulação teórica com as perspectivas de liderança, foi proposto um modelo hierárquico onde comportamentos de liderança ressaltados nas perspectivas estudadas são propostos como ações complementares associadas mecanismos de motivação intrínsecos e extrínsecos para formar competências globais de liderança, e por via dessas competências influenciarem o desempenho de equipes. O estudo também propõe uma associação entre as competências de liderança do gerente de projeto e as capacidades dinâmicas da equipe, assim como das capacidades com o desempenho das equipes. O modelo conceitual foi testado estatisticamente em 50 equipes de consultoria que atuam em projetos da empresa Elogroup, e avaliado através da modelagem estrutural baseada em mínimos quadrados parciais (PLS) e de técnicas de bootstrapping para calcular a significância dos efeitos estimados. Verificou-se os efeitos positivos das competências de liderança abordadas por este estudo no desempenho de equipes de consultoria, avaliado em termos da satisfação de clientes e da capacidade das equipes de criarem novos projetos junto a um mesmo cliente, mas não no lucro bruto obtido nos projetos. Os resultados da análise não mostraram qualquer efeito estatisticamente significante dos comportamentos de liderança transformacional, transacional, instrumental e empoderadora nas capacidades dinâmicas das equipes.

\section{Palavras-chave}

Liderança Transformacional; Liderança Transacional; Liderança Instrumental; Liderança Empoderadora; Capacidades Dinâmicas; Desempenho 


\section{Abstract}

Esteves; Felipe de Sousa. Cavazzotte, Flávia de Souza Costa Neves (Advisor). Global Leadership Competencies, Dynamic Capabilities and Performance in Project Teams. Rio de Janeiro, 2020. 125p. Tese de Doutorado - Departamento de Administração, Pontifícia Universidade Católica do Rio de Janeiro.

This thesis proposes a theoretical model that articulates the conceptual connections between the transformational, transactional (BASS, 1985), instrumental (ANTONAKIS \& HOUSE, 2014) and empowering (PEARCE \& SIMS, 2002) perspectives of leadership in generating dynamic capacities and obtaining competitive advantage in project teams. Based on theories of motivation and its theoretical articulation with the perspectives of leadership, a hierarchical model was proposed where leadership behaviors highlighted in the studied perspectives are presented as complementary actions associated to intrinsic and extrinsic motivation mechanisms to form global leadership competencies, and via these competencies influence the performance of project teams. The study also proposes an association between the leadership competencies of the project manager and the team dynamic capabilities, as well as these capabilities with the performance of the teams. The conceptual model was statistically tested in 50 project teams from Elogroup consulting company, evaluated using structural modelling based on partial least squares (PLS) and bootstrapping techniques to calculate the significance of the estimated effects. The positive effects of the leadership skills addressed by this study were verified on the performance of consulting teams, evaluated in terms of client satisfaction and the team's ability to create new projects with the same client, but not on the gross profit of the projects. The results of the analysis did not show any statistically significant effect of transformational, transactional, instrumental and empowering leadership behaviors on the dynamic capabilities of the teams.

\section{Keywords}

Transformational Leadership; Transactional Leadership; Instrumental Leadership; Empowering Leadership; Dynamic Capabilities; Performance 


\section{Sumário}

1 Introdução 12

1.1. Contextualização 12

1.2. Perguntas de Pesquisa 14

$\begin{array}{ll}\text { 1.3. Objetivos } & 16\end{array}$

1.3.1 Objetivo Final 16

1.3.2 Objetivos Secundários 16

1.4. Relevância do Estudo 17

$\begin{array}{ll}\text { 1.5. Delimitação do Estudo } & 18\end{array}$

2 Referencial Teórico 20

2.1. Liderança 20

2.1.1 Carisma e Liderança Carismática 22

2.1.2 Liderança Transformacional e Liderança Transacional 26

2.1.3 Liderança Instrumental 31

2.1.4 Empoderamento e Liderança Empoderadora 36

2.1.4.1 Empoderamento 36

2.1.4.2 Liderança Empoderadora $\quad 40$

2.1.5 Competências globais de liderança: integrando perspectivas 47

2.2. Estratégia 51

2.2.1. Estratégia e o Processo de Administração Estratégica 51

2.2.2. Vantagem Competitiva e o Processo de Criação de Valor 53

2.2.3. Capacidades Dinâmicas 55

2.3. Implicações da Liderança para a Geração de Capacidades

$\begin{array}{ll}\text { Dinâmicas } & 61\end{array}$

2.3.1. Lideranças transformacional, transacional e capacidades dinâmicas 62

2.3.2. Liderança instrumental e capacidades dinâmicas 64

2.3.3. Liderança empoderadora e capacidades dinâmicas 66

2.4. Capacidades Dinâmicas e Desempenho 68 
3. Metodologia 71

3.1. Seleção dos Informantes $\quad 71$

3.2. Instrumentos de Coleta de Dados 72

3.3. Coleta dos Dados 75

4 Análise dos Resultados $\quad 76$

4.1. Características Demográficas da Amostra 76

4.2. Análise do Modelo de Mensuração 77

4.3. Análise do Modelo Estrutural 83

4.4. Estudo Exploratório Sobre o Construto Capacidades Dinâmicas 88

5. Conclusão 91

5.1. Discussão e Síntese do Estudo 91

5.2. Contribuições do Estudo 94

5.3. Limitações do Método 95

5.4. Agenda de Pesquisas Futuras 96

6 Referências Bibliográficas 98

Apêndice A Questionário 01 (Líderes) 117

Apêndice B Questionário 02 (Subordinados/Seguidores) 120 


\section{Lista de Figuras}

Figura 1 - Liderança instrumental e suas dimensões 33

Figura 2 - Processo de empoderamento 38

Figura 3 - Proposições de pesquisa. 51

Figura 4 - Etapas do processo de administração estratégica 53

Figura 5 - Valor apropriado versus valor criado. 54

Figura 6 - Fundamentos das capacidades dinâmicas. 58

Figura 7 - Modelo de capacidades dinâmicas de Pavlou e Sawy (2011) 59

Figura 8 - Modelo estrutural 87

Figura 9 - Testes de significância (modelo capacidades dinâmicas) 90 


\section{Lista de Tabelas}

Tabela 1 - Fatores que levam ao potencial estado de impotência

Tabela 2 - Distinção entre a liderança empoderadora e as construções de liderança relacionadas

Tabela 3 - Perspectivas de liderança e mecanismos de motivação 50

Tabela 4 - Capacidades dinâmicas

Tabela 5 - Liderança instrumental e capacidades dinâmicas. 66

Tabela 6 - Escalas adotadas para medir o construto capacidades dinâmicas

Tabela 7 - Escalas adotadas para medir os construtos liderança transformacional, liderança instrumental e liderança empoderadora

Tabela 8 - Modelo de mensuração reflexivo (Questionário 1): resultados gerais 78

Tabela 9 - Modelo de mensuração reflexivo (Questionário 1): resultados

Tabela 10 - Modelo de mensuração reflexivo (Questionário 2): resultados gerais

Tabela 11 - Modelo de mensuração reflexivo (Questionário 2): resultados 81

Tabela 12 - Modelo de mensuração formativo: efeitos diretos 82

Tabela 13 - Modelo estrutural: efeitos totais $\quad 84$

Tabela 14 - Itens utilizados para medir a capacidade de aprendizagem $\quad 88$ 


\section{Introdução}

\section{1.}

\section{Contextualização}

O ambiente de negócios está cada vez mais complexo e competitivo, como consequência de um mundo crescentemente interconectado, imprevisível e volátil. As mudanças no contexto político, social e ambiental acontecem de forma rápida e frequente, e afetam significativamente as organizações. Em paralelo, os avanços sem precedentes nas tecnologias de informação, o consequente desenvolvimento de novos canais de comunicação, o exponencial crescimento das mídias sociais e a alteração dos hábitos de consumo e da maneira como as pessoas se relacionam socialmente, fazem com que as empresas tenham que repensar seus modelos de negócios constantemente. $\mathrm{O}$ ambiente em mutação envolve a incerteza e, portanto, a necessidade de desenvolver um novo repertório de soluções (LAUREIROMARTÍNEZ \& BRUSONI, 2018; MARCH, 2006). Nesse contexto, a seleção e implementação de estratégias de negócio que promovam vantagens competitivas podem ser decisivas para a sobrevivência das empresas.

As organizações de hoje necessitam de líderes capazes de pensar e agir estrategicamente (ROWOLD, 2014) e que monitorem mercados externos e internos, concorrentes e oportunidades (BOAL, 2007). O processo de avaliação e escolha da estratégia adequada requer o entendimento dos fatores econômicos e socioambientais que influenciam a empresa e a identificação dos recursos organizacionais e das competências essenciais necessárias à sua implementação. Líderes atentos devem ser capazes de reconhecer o contexto e desenvolver capacidades flexíveis, que explorem novos domínios e tragam inovação, e, ao mesmo tempo, que apliquem o conhecimento existente (LAUREIROMARTÍNEZ \& BRUSONI, 2018; MARCH, 1991; WEICK \& SUTCLIFFE, 2006).

Líderes eficazes precisam usar recursos com eficiência, considerar o ambiente externo e garantir que as organizações se adaptem a esse ambiente. 
Antonakis e House (2014) argumentam que uma liderança organizacional eficaz também depende da expertise e da formulação e implementação de soluções para problemas sociais complexos. Sendo assim, o líder não é só um influenciador de pessoas, mas também deve ser capaz de identificar objetivos estratégicos e táticos, enquanto monitora tanto os resultados da equipe quanto o ambiente.

As organizações ganham vantagens competitivas na medida em que desenvolvem novas estratégias com maior agilidade do que os concorrentes, por meio do reconhecimento de diferentes recursos de valor (TEECE, 2007), e conseguem transformar as capacidades operacionais existentes em novas capacidades, que melhor correspondam ao ambiente em constante mutação. As capacidades dinâmicas são aquelas capazes de reconfigurar capacidades operacionais já existentes, e representam um desafio importante na busca por uma vantagem competitiva sustentável (GREWAL \& SLOTEGRAAF, 2007). Enquanto as capacidades operacionais representam a competência para executar atividades do dia-a-dia, as capacidades dinâmicas representam a competência de inovação da organização, e têm o objetivo de mudar o produto, o processo de produção, a escala ou os mercados atendidos (WINTER, 2003).

A manutenção da competitividade ao longo do tempo faz com que as organizações tenham que equilibrar a tensão entre a necessidade de inovar e a necessidade de produzir. Essas demandas, por vezes conflitantes, devem ser estimuladas pelos líderes das organizações. Para isso, os líderes da organização devem ir além dos incentivos tradicionais, e promover e apoiar a tomada de iniciativas e a cooperação. Esse tipo de liderança envolve a transferência de poder dos líderes para os seguidores, permitindo que as organizações e unidades organizacionais sejam flexíveis, ágeis e adaptáveis em resposta a mudanças associadas a um mundo volátil e imprevisível (UHL-BIEN \& ARENA, 2018).

Com base no exposto, esta tese tem como foco a relação entre liderança, capacidades dinâmicas e desempenho nas organizações, e propõe de forma original que diferentes mecanismos de influência ativados pelas lideranças atuam de forma conjugada para promover capacidades dinâmicas, e assim posicionar as suas organizações e as pessoas dentro delas para serem adaptáveis diante de desafios complexos. O estudo parte da premissa de que a manutenção da competitividade e o desempenho organizacional necessitam que líderes combinem mecanismos de influência verticais e horizontais para serem capazes de estimular 
não apenas as capacidades operacionais, mas também as capacidades dinâmicas. Assim, o estudo propõe a integração de quatro perspectivas de liderança transformacional, transacional (BASS, 1985), instrumental (ANTONAKIS \& HOUSE, 2014) e empoderadora (PEARCE \& SIMS, 2002) - sua conexão com a orquestração das capacidades dinâmicas em empresas, e como antecedente de resultados organizacionais.

As perspectivas tradicionais, verticais de liderança, como a transformacional e a instrumental, têm se mostrado relevantes para explorar capacidades atuais (ANTONAKIS \& HOUSE, 2014; JUDGE \& PICCOLO, 2004), mas não suficientes para que uma equipe ou organização desenvolva capacidades dinâmicas e obtenha vantagem competitiva em um ambiente complexo (UHLBIEN \& ARENA, 2018). Torna-se relevante, portanto, analisar do ponto de vista teórico-conceitual as conexões e complementaridades entre mecanismos de influência enfatizados por diferentes perspectivas de liderança na geração de capacidades dinâmicas e no desempenho, bem como investigar sua importância relativa através da pesquisa aplicada. Neste sentido, o presente estudo desenvolve e testa um modelo conceitual que articula princípios das perspectivas transformacional, transacional (BASS, 1985), instrumental (ANTONAKIS \& HOUSE, 2014) e empoderadora (PEARCE \& SIMS, 2002) da liderança, propondo uma integração dessas perspectivas, sua conexão com a geração de capacidades dinâmicas e, consequentemente, como antecedente do desempenho organizacional.

\section{2.}

\section{Perguntas de Pesquisa}

Como colocado anteriormente, a busca pela vantagem competitiva requer que as organizações sejam capazes de desenvolver capacidades flexíveis, que tragam inovação e ao mesmo tempo explorem o conhecimento existente. Essa capacidade de alcançar novas formas de vantagem competitiva depende do que a literatura denomina "capacidades dinâmicas". O termo "capacidades" enfatiza o papel fundamental da gestão estratégica na adaptação, integração e reconfiguração adequadas de habilidades organizacionais internas e externas, recursos e competências funcionais para atender aos requisitos de um ambiente em mudança; 
já o termo "dinâmico" refere-se à capacidade de renovar competências de modo a alcançar congruência com o ambiente de negócios em mudança (TEECE at. al, 1997). As capacidades dinâmicas envolvem uma ampla gama de recursos e capacidades da organização. A sistematização do uso desses recursos em rotinas organizacionais depende de gestores que tenham um nível adequado de autoridade para mobilizá-los, organizá-los e coordená-los. Esta tese parte da premissa de que a atuação dos líderes é um fator fundamental para esse processo.

Para aprofundar o conhecimento sobre o papel dos líderes no desenvolvimento de capacidades dinâmicas, bem como a importância de diferentes atributos da liderança, tanto os associados à liderança vertical característica das lideranças transformacional, transacional e instrumental, quanto os associados ao compartilhamento da liderança através do empoderamento da equipe, esta tese busca responder aos seguintes questionamentos: Que elementos de diferentes perspectivas sobre a liderança podem ser integrados para ampliar o conhecimento sobre como líderes promovem capacidades dinâmicas em organizações/unidades organizacionais? Qual a importância relativa de atributos transformacionais, transacionais, instrumentais e empoderadores em um líder para fomentar capacidades dinâmicas em organizações/unidades organizacionais, e como esses atributos se articulam para viabilizar essas capacidades? Em que grau a liderança e tais capacidades estão associadas ao desempenho dessas organizações/unidades organizacionais? Esta tese encaminha essas questões, apresentando um modelo teórico-conceitual original e investigando empiricamente sua adequação no contexto de empresas privadas. $\mathrm{O}$ estudo avalia o impacto das lideranças transformacional, transacional, instrumental e empoderadora nas capacidades dinâmicas, bem como sua contribuição conjunta como antecedentes do desempenho de organizações/unidades organizacionais. 


\section{3. \\ Objetivos}

\subsection{1 \\ Objetivo Final}

O objetivo central desta tese é propor e testar um modelo teórico-conceitual que articule o papel da liderança para a geração de capacidades dinâmicas, bem como o impacto dessas capacidades na criação de vantagens competitivas. Mais especificamente, esta tese investiga a importância relativa de atributos associados às perspectivas de liderança transformacional, transacional, instrumental $e$ empoderadora em líderes de equipes de projeto, para (1) o desenvolvimento de capacidades dinâmicas nessas equipes; (2) o desempenho formal das equipes, incluindo: (a) o desempenho financeiro do projeto (lucro), e (b) o desempenho do projeto na ótica do cliente (satisfação dos clientes); e (3) o empreendedorismo nas equipes de projeto, i.e., a capacidade da equipe de criar novos projetos junto a um clientes que permitam desenvolver novos produtos (indicador de desempenho criado e utilizado pela empresa Elogroup, por ela denominado DNA empreendedor).

\subsection{2 \\ Objetivos Secundários}

1. Desenvolver um arcabouço teórico-conceitual que permita articular as perspectivas de liderança transformacional, transacional, instrumental e empoderadora em um modelo integrado de liderança.

2. Desenvolver um modelo teórico-conceitual que permita associar as perspectivas de liderança transformacional, transacional, instrumental e empoderadora ao desenvolvimento de capacidades dinâmicas, bem como ao desempenho em equipes de projeto.

3. Avaliar os atributos de liderança mais relevantes para que uma empresa desenvolva capacidades dinâmicas e o DNA empreendedor em equipes.

4. Investigar a contribuição relativa a manifestações da liderança que assumem "verticalidade" na relação entre líder-liderado (liderança transformacional, transacional e instrumental) e sua relevância para que uma equipe ou organização desenvolva capacidades dinâmicas, alcance 
metas de projeto e atuem de forma empreendedora vis-à-vis as manifestações da liderança horizontal (empoderadora).

5. Investigar empiricamente as hipóteses de pesquisa propostas, através de dados coletados junto a líderes e equipes de projeto que atuam no ambiente empresarial.

\section{4 . Relevância do Estudo}

Esta tese oferece uma importante contribuição teórica para a compreensão do papel da liderança como alavanca para o desempenho organizacional, através das capacidades dinâmicas em organizações inovadoras. $\mathrm{O}$ estudo das perspectivas de liderança transformacional, transacional, instrumental e empoderadora no ambiente atual, em constante mudança, oferece uma oportunidade para um melhor entendimento do papel dos gestores enquanto líderes nesse contexto, pois acredita-se que perspectivas tradicionais verticais são relevantes mas não suficientes para que uma equipe ou organização desenvolva capacidades dinâmicas e obtenha vantagem competitiva, dadas as complexidades inerentes ao ambiente de negócios da atualidade (UHL-BIEN \& ARENA, 2018).

De maneira original, este estudo propõe uma aproximação oportuna entre fenômenos estudados no campo de comportamento organizacional e no campo da estratégia de negócios, através da articulação entre diferentes perspectivas teóricas sobre a liderança (aqui consideradas complementares) e a teoria das capacidades dinâmicas, respectivamente. A aproximação entre essas temáticas é considerada particularmente oportuna e promissora na literatura contemporânea das áreas de liderança e gestão (BARRICK, THURGOOD, SMITH \& COURTRIGHT, 2015; DIHN et al., 2014; STURM, VERA \& CROSSAN, 2017). Especificamente, esta tese propõe que mecanismos de influência inerentes às perspectivas transformacional, transacional, instrumental e empoderadora da liderança atuam como alavancas complementares no desenvolvimento de capacidades dinâmicas, que por sua vez, geram vantagens competitivas.

Em um ambiente de negócios dinâmico, é cada vez mais difícil o desenvolvimento e a manutenção de vantagens competitivas. É preciso renovar competências de modo a alcançar compatibilidade com esse ambiente em 
constante mutação (TEECE et al., 1997). O papel dos líderes tem marcante importância nesse contexto. Além de influenciar pessoas, líderes eficazes devem ser capazes de pensar e agir estrategicamente (ROWOLD, 2014), assim como compartilhar poder e alocar autonomia e responsabilidades a seguidores, equipes ou coletivos para que os funcionários melhorem a motivação interna e alcancem o sucesso no trabalho (CHEONG et al., 2019).

Dentre as contribuições desta tese, pode-se destacar a geração de conhecimento original, inovador e relevante ao grande campo de estudos sobre liderança, no qual há demanda crescente pela integração de perspectivas teóricas (DIHN et al., 2014; ANTONAKIS, 2018). Nesse sentido, a contribuição da tese reside na integracão das perspectivas teóricas sobre liderança acima mencionadas (através de diferentes mecanismos de motivação aos quais esses comportamentos estão associados) e na proposição de sua importância complementar na promoção de capacidades dinâmicas e o desempenho no contexto organizacional. Simultaneamente, a pesquisa apoia a construção do conhecimento sobre a liderança organizacional, uma vez que analisa as associações teórico-conceituais propostas através de resultados observados no contexto empresarial brasileiro, com contribuições práticas que podem ter impacto na efetividade da gestão.

O conhecimento desenvolvido também permite a identificação dos atributos essenciais à liderança efetiva, capazes de promover vantagens competitivas em empresas, assim produzindo bases para o desenvolvimento gerencial e capacitação de lideranças, particularmente de equipes de projeto. Dessa forma, a pesquisa contribui para a prática da liderança, gerando informações úteis para programas de desenvolvimento e formação de lideranças nas empresas, com potencial para a geração de vantagens competitivas, capazes de alavancar o desempenho organizacional.

\section{5 . Delimitação do Estudo}

Este estudo se limitará à análise do modelo teórico proposto no contexto de empresas privadas e com fins lucrativos. Mais especificamente, a análise empírica se baseia em dados coletados em uma empresa brasileira de consultoria com sede no Rio de Janeiro: a Elogroup. As equipes da empresa e os projetos por elas 
executados constituem a unidade de análise no componente empírico deste estudo, e portanto, o estudo tem como foco a avaliação do modelo teórico proposto na previsão do desempenho de equipes de projeto.

A Elogroup conta com aproximadamente 300 colaboradores e tem atuação em 12 países, executa projetos consultivos nas áreas de gestão de processos e da inovação. A empresa é considerada empreendedora e inovadora, sendo detentora de diversos prêmios que reconhecem sua trajetória (e.g. Eleita em $1^{\circ}$ lugar na categoria Empresa Graduada do Prêmio Nacional de Empreendedorismo Inovador em 2013; eleita a $2^{\mathrm{a}}$ melhor empresa para se trabalhar com sede no Rio de Janeiro em 2013). A escolha dessa organização para testar o modelo desenvolvido se deve ao fato de que empresas consideradas inovadoras seriam os arranjos ideais para o desenvolvimento de capacidades dinâmicas (TEECE et al. 1997; TEECE, 2007; 2016).

A análise será no nível das equipes de trabalho que compõem a Elogroup, pois equipes de projeto de consultoria funcionam como unidades independentes, cada uma com um projeto e cliente distintos. Atualmente, muitas empresas no setor de serviços se estruturam dessa forma. Essas equipes também estão geograficamente dispersas e cada uma tem metas e resultados independentes umas das outras. Estruturas organizacionais estáveis formadas por pessoas que aprenderam ao longo do tempo a trabalhar bem juntas podem ser ferramentas poderosas, contudo, dada a velocidade da mudança, a intensidade da concorrência no mercado e a imprevisibilidade das necessidades dos clientes hoje em dia, muitas vezes não há tempo suficiente para formar esse tipo de estrutura. Ao invés disso, as organizações devem cada vez mais reunir não apenas seus próprios funcionários distantes de várias disciplinas e divisões, mas também especialistas externos e partes interessadas; e apenas dissolvê-los quando atingirem seu objetivo ou quando surgir uma nova oportunidade (EDMONDSON, 2012).

O nível de análise de equipes de trabalho de uma organização também permite avaliar com maior acuidade tanto as dinâmicas verticais de influência, do líder para o seguidor (associadas às perspectivas de liderança transformacional, transacional e instrumental), quanto a distribuição de poder em dinâmicas horizontais de influência entre líderes e seguidores (associada à perspectiva da liderança empoderadora) nessas mesmas equipes. 


\section{2 \\ Referencial Teórico}

O referencial teórico deste estudo se inicia com a apresentação de conceitos e perspectivas do campo da liderança, onde se pretende aprofundar o tema, com foco nas perspectivas de liderança transformacional, transacional, liderança instrumental e liderança empoderadora e seus conceitos seminais. Em seguida, é apresentada a literatura sobre estratégia, com uma síntese sobre os seus principais conceitos e o processo de administração estratégica aderentes ao tema desta tese. Nesta seção, são abordados o conceito de vantagem competitiva e o processo de criação de valor, que servirão de base para a introdução ao conceito de capacidades dinâmicas e seu aprofundamento. Com base nas perspectivas de liderança e no conceito de capacidades dinâmicas, são articuladas em seguida as implicações da liderança para a geração de capacidades dinâmicas, e sobre essa base teórica são derivadas hipóteses de pesquisa para as associações entre liderança, capacidades dinâmicas e desempenho, assim consolidando o modelo teórico proposto na tese. A última parte deste referencial teórico fundamenta a associação entre capacidades dinâmicas e desempenho.

\section{1.}

\section{Liderança}

A liderança é um construto extremamente complexo e multifacetado. É estudada por pesquisadores acadêmicos há mais de um século (NORTHOUSE, 2015) e não existe ainda uma abordagem considerada como definitiva. Existem dezenas de teorias a respeito de liderança na literatura sobre o tema, considerando exclusivamente o contexto organizacional (DINH et al., 2014). Segundo Stogdill (1974), o número de teorias sobre liderança é tão grande quanto o número de pesquisadores tentando defini-la. Para Antonakis e Day (2017), no campo das ciências comportamentais, a liderança é provavelmente o fenômeno sobre o qual mais foi escrito e menos se tem certezas. 
Embora a liderança, de um modo geral, não seja difícil de identificar na prática, é difícil defini-la com precisão. Devido a sua natureza complexa, não existe uma definição específica e amplamente aceita de liderança atualmente (ANTONAKIS \& DAY, 2017). Mesmo nessa ausência, para os propósitos desta tese será utilizada a seguinte definição, proposta por Antonakis e Day (2017, p. 5):

"A liderança é um processo formal ou informal, enraizado em um contexto e indutor de objetivos, que ocorre entre um líder e um seguidor, grupos de seguidores ou instituições. A ciência da liderança é o estudo sistemático desse processo e seus resultados, bem como de como esse processo depende dos traços e comportamentos do líder, das inferências dos observadores sobre as características do líder e das atribuições do observador em relação aos resultados da entidade liderada."

Estabelecida a definição de liderança, também é importante diferenciá-la dos conceitos de poder e de gestão, pois ambos costumam ser confundidos com liderança. O poder refere-se aos meios potenciais que os líderes têm para influenciar os outros. A capacidade de conduzir os outros em direção a algum objetivo e levá-los a empreender dispendiosos esforços para concretizar tal objetivo requer que se tenha poder; se alguém tem autoridade formal ou não, não importa (ANTONAKIS \& DAY, 2017). Já a gestão, enquanto orientada por tarefas, resultando em estabilidade fundamentada na racionalidade, nos meios burocráticos e no cumprimento das obrigações contratuais (ou seja, transações) se distingue da liderança, que é orientada por propósitos, baseada em valores, ideais, visão, símbolos e trocas emocionais. Embora líderes e gerentes possam ser vistos como indivíduos diferentes (ZALEZNIK, 1977), a liderança bem-sucedida também requer gestão bem-sucedida. Pode-se dizer, portanto, que liderança e gestão são complementares, mas a liderança vai além da gestão e é necessária para resultados que superam expectativas (BASS, 1985, 1998; BASS \& RIGGIO, 2006).

Em sua essência, a liderança é funcional e necessária por diversas razões (LORD, 1977). Em nível de supervisão, é necessária para complementar os sistemas organizacionais (KATZ \& KAHN, 1978) e resolver problemas complexos sociais e de tarefas (FLEISHMAN, MUMFORD, ZACCARO, LEVIN, KOROTKIN \& HEIN, 1991; MORGESON, 2005; MORGESON, DERUE, \& KARAM, 2010). No nível estratégico, é necessária para direcionar e orientar os recursos organizacionais e humanos para os objetivos estratégicos da organização e garantir que as funções organizacionais estejam alinhadas com o 
ambiente externo (ZACCARO, 2001). A liderança é importante não só para motivar os seguidores, como também para mobilizar recursos para o cumprimento da missão da organização, sendo essencial para a inovação, adaptação e o bom desempenho organizacional.

Diversas são as perspectivas existentes sobre liderança, contudo, este estudo abordará as perspectivas da liderança transformacional, transacional, instrumental e empoderadora. Nas próximas seções deste capítulo as premissas teóricas dessas perspectivas são apresentadas.

\subsection{1}

\section{Carisma e Liderança Carismática}

A articulação conceitual da perspectiva transacional-transformacional emerge a partir de uma mudança de paradigma no campo de estudos sobre liderança, cuja origem se situa nos fundamentos da teoria da liderança carismática, perspectiva que teve um enorme impacto sobre a liderança como um domínio científico (ANTONAKIS \& DAY, 2017). Portanto, para uma melhor compreensão da perspectiva transformacional, não se pode prescindir de uma boa compreensão da perspectiva carismática. Juntas, essas perspectivas constituem o que Hunt (1999) denomina "escola da nova liderança".

A articulação da perspectiva carismática foi considerada uma ruptura nos modelos de liderança existentes na época em que surgiu (BRYMAN, 1992). A maioria dos escritores credita a Weber (1947) ter cunhado o termo carisma e fornecido a primeira explicação teórica moderna para o impacto da liderança carismática sobre os seguidores (ANTONAKIS \& DAY, 2017). Weber (1947) usou o termo carismático para descrever um tipo de líder que poderia trazer mudanças sociais. Weber (1968) acreditava que os seguidores de um líder carismático voluntariamente colocam seu destino nas mãos de seu líder e apoiam a missão. $\mathrm{O}$ autor argumentou que a autoridade carismática é diferente da autoridade burocrática, e que no cerne do carisma há um apelo emocional cuja atitude é revolucionária e superestima tudo, fazendo uma ruptura com todas as normas tradicionais ou racionais.

Outros autores desenvolveram o conceito a partir do trabalho de Weber. A perspectiva estruturalista de Etzioni (1964), por exemplo, enfoca o efeito que a 
liderança formal exerce sobre os indivíduos e a fonte de poder que é usada para exercer influência sobre os seguidores. Etzioni (1961) chamou o poder simbólico de "carisma". De acordo com o autor, maior comprometimento e menos alienação serão demonstrados nos seguidores quando seus líderes estiverem usando poder simbólico acima do material ou físico.

Cientistas políticos também se interessaram pelo carisma e tentaram expressamente defini-lo (DAVIES, 1954; FRIEDRICH, 1961; TUCKER, 1968). Em linha com a noção weberiana de carisma, Downton (1973) propôs uma teoria de liderança que consistia em três fatores: liderança carismática, inspiradora e transacional e foi um dos primeiros a opor os processos de influência contratuais (transacionais) do agente principal contra a autoridade carismática. Para o autor, a liderança transacional significava um processo de troca semelhante às relações contratuais na vida econômica, e contingente à boa fé dos participantes. Downton (1973) acreditava que o cumprimento dos compromissos transacionais constitui a base da confiança entre os líderes e seus seguidores, fortalece seu relacionamento e resulta em um clima mutuamente benéfico para que outras transações ocorram. $\mathrm{O}$ autor fez distinção entre transações positivas e negativas. Transações positivas ocorrem quando os seguidores recebem recompensas contingentes ao alcance dos resultados desejados, enquanto transações negativas referem-se à não conformidade dos seguidores, resultando em punição.

Downton (1973) argumentou que os líderes carismáticos têm efeitos poderosos sobre os seguidores por causa de seus ideais transcendentais e autoridade que facilitam a identificação dos seguidores com o líder. Nessas condições, a confiança é solidificada à medida que as trocas psicológicas ocorrem. Esse compromisso e confiança são ainda mais ampliados pela liderança inspiradora. O líder inspirador é persuasivo e encoraja os seguidores a investir e fazer sacrifícios em direção aos ideais por ele definidos, dá aos seguidores um senso de propósito e cria significado para ações distintas do apelo carismático. Os seguidores se relacionam com esses tipos de líderes, mas não os reverenciam necessariamente. Assim, a liderança inspiradora é, aparentemente, independente da liderança carismática; de acordo com Downton (1973), a liderança inspiradora não promove a dependência do seguidor em relação ao líder. Em vez disso, “o compromisso inspirador é sempre contingente à apresentação simbólica contínua do líder da visão de mundo do seguidor” (p. 80). Downton argumentou ainda que, 
embora as relações carismáticas entre líderes e seguidores levem a relações inspiradoras, nem todas as relações inspiradoras levam a relações carismáticas. Finalmente, Downton propôs que todas as fontes de liderança, sejam transacionais, inspiradoras ou carismáticas, deveriam ser usadas em graus variados.

House (1977) foi o primeiro a apresentar um quadro teórico integrado e proposições testáveis para explicar o comportamento de líderes carismáticos. Em sua publicação seminal (HOUSE, 1977), o autor se referiu aos líderes carismáticos como tendo as habilidades persuasivas necessárias para influenciar os outros. A base para o apelo carismático da teoria desenvolvida por House é a interação emocional que ocorre entre os seguidores e seu líder. Com base na missão, os líderes carismáticos despertam motivos nos seguidores para realizar seus ideais e valores. Em contrapartida, os seguidores demonstram afeição e admiração pelo líder e internalizam um senso de identificação com ele. Segundo House (1977), líderes carismáticos demonstram confiança em suas próprias habilidades e em seus seguidores, estabelecem altas expectativas para ambos e demonstram confiança de que essas expectativas podem ser alcançadas. Como resultado, esses líderes se tornam modelos e objetos de identificação dos seguidores, que, por sua vez, emulam os ideais e valores de seus líderes e são inspirados e motivados a alcançar resultados extraordinários. House argumentou que os líderes carismáticos exibem muita autoconfiança, assertividade pró-social (dominância) e convicção moral. Esses líderes modelam o comportamento que esperam de seus seguidores, exemplificam o sacrifício próprio e se engajam em ações de construção de imagem e autopromoção para se tornarem poderosos e competentes. A teoria de House foi concebida em um momento em que a liderança estava sendo questionada (ANTONAKIS et al., 2004; DAY \& ANTONAKIS, 2012; ANTONAKIS \& DAY, 2017), e suas ideias foram catalisadoras para um novo movimento no campo de estudos sobre a liderança (ANTONAKIS et al., 2016; ANTONAKIS \& DAY, 2017).

Conger e Kanungo (1988, 1998) propuseram uma teoria de liderança carismática em que um líder é legitimado com base nas percepções que seus seguidores têm de seus comportamentos. Os autores propuseram que os indivíduos são validados como líderes por seus seguidores através de um processo comportamental de três estágios, que podem ocorrer em qualquer ordem e existir 
concomitantemente (CONGER \& KANUNGO, 1998). No primeiro estágio, líderes carismáticos eficazes avaliam o status quo para determinar as necessidades dos seguidores, avaliar os recursos disponíveis no grupo e articular um argumento convincente para despertar seu interesse. No segundo estágio, os líderes articulam uma visão do futuro que inspirará a ação do seguidor para alcançar objetivos que sejam instrumentais no cumprimento da visão. No terceiro estágio, os líderes criam uma aura de confiança e competência, demonstrando a conviç̧ão de que a visão é realizável. Os líderes usam meios e conhecimentos não convencionais para inspirar ações e mostrar como os objetivos podem ser alcançados, e servem como modelos para promover a ação dos seguidores. A organização atinge seus objetivos, pois esse processo de três estágios gera uma alta confiança (por parte dos seguidores) no desempenho do líder e do seguidor (CONGER \& KANUNGO, 1998).

Influenciado pelos trabalhos de Conger e Kanungo; Shamir, House e Arthur publicaram um artigo (SHAMIR, HOUSE \& ARTHUR, 1993) propondo uma teoria da liderança carismática motivacional baseada no autoconceito (HUNT, 1999). Shamir, House, \& Arthur (1993) propuseram uma estrutura integrativa para explicar como os líderes envolvem os autoconceitos dos seguidores. De acordo com os autores, líderes carismáticos afetam os seguidores como resultado de mecanismos motivacionais que são induzidos pelos comportamentos do líder. Como resultado do comportamento do líder, os mecanismos motivacionais desencadeiam os efeitos no autoconceito do liderado que levam ao comprometimento pessoal com a missão do líder, o comportamento de autosacrifício, a cidadania organizacional e o significado da tarefa. Esses efeitos são reforçados pela geração de auto-expressão e consistência por parte dos seguidores.

Pode-se dizer que é nesta fase que ocorreu o início da mudança de paradigma do que hoje é chamado de "liderança tradicional" para a denominada escola da "nova liderança" (HUNT, 1999). A liderança carismática e a liderança transformacional têm sido o foco de muitas pesquisas (YUKL, 1999); essas abordagens ajudaram a introduzir o paradigma de liderança que domina nos dias atuais (ANTONAKIS, CIANCIOLO \& STERNBERG, 2004; DAY \& ANTONAKIS, 2012; HUNT, 1999; LOWE \& GARDNER, 2000).

$\mathrm{Na}$ próxima seção, são apresentados os conceitos associados à liderança transformacional, que teve como publicações seminais o texto produzido por 
Burns (1978) e posteriormente o livro de Bass (1985), Liderança além das expectativas, enfatizando a liderança transformacional com o carisma como componente (HUNT, 1999).

\subsection{2}

\section{Liderança Transformacional e Liderança Transacional}

Atualmente, a teoria da liderança transformacional pode ser considerada uma das abordagens mais estudadas no campo da liderança (DINH et al., 2014). A perspectiva da liderança transformacional foi apresentada pela primeira vez no texto de Burns (1978). O autor propôs que a liderança poderia ser exercida através de duas abordagens, transacional ou transformadora. Na primeira, o foco estaria nas trocas sociais que acontecem entre líder e liderado, tais como promoções e incentivos materiais conforme o desempenho, e em atender aos interesses pessoais do seguidor. Na abordagem transformadora, líderes e liderados se juntam e, a partir de valores éticos e morais comuns, procuram atingir os objetivos do grupo ou da organização, deixando de lado seus interesses pessoais (ANTONAKIS, 2012; BASS \& RIGGIO, 2006; BURNS, 1978).

Tendo por base os conceitos estabelecidos por Burns (1978), Bass (1985) apresentou uma visão mais abrangente, onde ambas as abordagens (transacional e transformacional), antes de serem excludentes, poderiam ser exercidas de forma complementar. A perspectiva de liderança transacional envolve uma relação de troca entre o líder e o seguidor para ir ao encontro dos seus interesses próprios. $\mathrm{Na}$ perspectiva de liderança transformacional, o líder consegue que o seguidor transforme os seus interesses próprios e imediatos em favor dos interesses do grupo para um desempenho acima das expectativas (BASS, 1999). A liderança transformacional não substitui a transacional, mas acrescenta eficácia à mesma, permitindo atingir resultados superiores (BASS, 1999).

A liderança transacional possui duas dimensões (BASS, 1999; JUDGE \& PICCOLO, 2004; BASS et al., 2003): (i) recompensa contingente e (ii) gestão por exceção: 


\section{Recompensa contingente:}

A recompensa contingente caracteriza-se pela definição de objetivos e clarificação das expectativas.

\section{Gestão por exceção}

A gestão por exceção pode ser ativa ou passiva. É ativa quando a líder monitora o desempenho de seus subordinados com muita proximidade, tomando ações corretivas o mais rápido possível, sempre que existirem desvios do que foi previamente definido. A gestão por exceção pode ser passiva quando apenas atua se o resultado não for o pretendido.

A liderança transacional busca atingir os resultados esperados, enquanto a liderança transformacional motiva a alcançar resultados acima do esperado (NORTHOUSE, 2015). Isso se daria como consequência, entre outros fatores, da maior conscientização dos liderados com relação à importância e valor dos objetivos comuns estabelecidos e de levar os seguidores a privilegiarem os interesses do grupo e da organização, acima dos seus próprios interesses (BASS, 1990; BASS \& AVOLIO, 1990).

A liderança transformacional possui quatro dimensões (BASS, 1998): (i) carisma ou influência idealizada, (ii) motivação inspiradora, (iii) estímulo intelectual e (iv) consideração individualizada.

\section{Influência idealizada}

A influência idealizada é o componente emocional da liderança (ANTONAKIS, 2012), refere-se à medida em que os seguidores de um líder buscam se identificar com o líder e imitá-lo, é usada para descrever líderes que pelo seu poder pessoal têm efeitos profundos e extraordinários sobre seus seguidores (BASS, 1985). Em tese, esses líderes são reverenciados por seguidores que demonstram lealdade e devoção à causa do líder, pois dão menos importância a seus interesses individuais (ANTONAKIS, 2012). Líderes transformacionais são capazes de fazer com que os objetivos pessoais e de auto realização dos seguidores mudem para a busca de um bem (objetivo) maior (BASS, 1998). Considerados como modelos, esses líderes proporcionam uma visão e um propósito para seus seguidores, são vistos como poderosos, confiantes e se preocupam com as consequências morais e éticas de suas ações. 
Segundo Antonakis (2012), líderes transformacionais concentram seguidores na missão do grupo, despertando sua necessidade de realização, de afiliação ou de poder. Líderes carismáticos comunicam-se através de imagens e símbolos, são persuasivos na comunicação de uma visão que promete um futuro melhor. Com esta visão e um senso de propósito, eles criam uma ligação emocional intensa com seus seguidores.

A influência idealizada pode ser dividida em componentes comportamentais e de atribuição. O componente da influência idealizada de atribuição refere-se às atribuições sobre o líder criadas pelos seus seguidores, é o resultado de como eles percebem o líder. Já o componente da influência idealizada comportamental, refere-se a comportamentos específicos do líder que podem ser diretamente observados por seus seguidores. Embora ambos os fatores estejam essencialmente ligados ao apelo carismático de um líder, eles são promulgados e medidos de maneira diferente.

\section{Motivação inspiradora}

A motivação inspiradora refere-se à capacidade do líder de motivar e inspirar os seus seguidores a alcançar metas ambiciosas, ao articular uma visão forte para o futuro (ANTONAKIS, 2012). Diferente da influência idealizada, esse fator acrescenta qualidades emocionais não intelectuais ao processo de influência do líder sobre os seus seguidores (BASS, 1985). O líder aumenta as expectativas dos seus seguidores e inspira a ação, passando a confiança de que eles podem alcançar objetivos mais ambiciosos. De acordo com Antonakis (2012), ao prever que são capazes de atingir metas ambiciosas, demonstrar confiança absoluta e acreditar que esse resultado ocorrerá, os seguidores são inspirados a alcançar um nível de desempenho exigido além das expectativas normais.

\section{Estímulo intelectual}

Distintivamente dos outros, o estímulo intelectual é o componente mais racional da liderança transformacional. $O$ estímulo intelectual enfatiza a capacidade do líder de expandir o potencial de seus seguidores. O líder apela ao intelecto dos seguidores, criando consciência e resolução de problemas, de pensamento e imaginação, de crenças e valores (BASS, 1985). Como resultado da estimulação intelectual, “a conceituação, compreensão e discernimento dos 
seguidores da natureza dos problemas que enfrentam e suas soluções são radicalmente alteradas" (BASS, 1985, p. 99). Ao serem incluídos no processo de solução de problemas, os indivíduos tornam-se motivados e comprometidos com o alcance das metas. Esse componente da liderança transformacional (estímulo intelectual) envolve desafiar as suposições, generalizações e estereótipos dos seguidores e os estimula a buscar maneiras de melhorar o desempenho atual (ANTONAKIS, 2012).

\section{Consideração individualizada}

A consideração individualizada refere-se ao grau de atenção de um líder às necessidades de realização, crescimento e apoio de seus seguidores. Bass (1985) afirmou que um líder que usa consideração individualizada fornece apoio socioemocional aos seguidores e está preocupado em desenvolver e capacitar seguidores para que atinjam o seu potencial mais elevado. Desta forma, o líder dá atenção individualizada e uma orientação de desenvolvimento aos seguidores (BASS, 1985). Este resultado é alcançado treinando e aconselhando seguidores, mantendo contato frequente com eles e os ajudando a se autorrealizar.

Os líderes transformacionais incentivam seus seguidores, estabelecem altos padrões de desempenho, ajudam os seguidores a se tornarem mais criativos e inovadores (BASS, 1985; YUKL, 1999). Líderes transformacionais motivam os seguidores a alcançar um desempenho além das expectativas, transformando as atitudes, crenças e valores dos seguidores (RAFFERTY \& GRIFFIN, 2004). Como resultado, os líderes transformacionais podem melhorar o desempenho dos funcionários e das organizações. Na literatura, os comportamentos dos líderes transformacionais têm sido associados a maior eficácia organizacional, satisfação do seguidor e estímulo a motivação do seguidor (ANTONAKIS \& DAY, 2017). Diversos estudos forneceram evidências para os efeitos positivos da liderança transformacional no desempenho do grupo e da organização, produção essa evidenciada em diversas revisões quantitativas da produção científica (e.g. JUDGE \& PICCOLO, 2004; LOWE ET AL., 1996).

Um funcionário é eficaz quando é um colaborador significativo do núcleo técnico da organização, um membro da equipe que vai além de sua função prescrita e que ajuda a organização a inovar (NG, 2017). Os líderes transformacionais são capazes de convencer os seus seguidores da importância do 
objetivo de uma organização e influenciá-los a contribuir com seus esforços para ajudá-lo a alcançar esse objetivo (através da exibição de maior desempenho das tarefas e comportamento de cidadania), assim como de motivar esses seguidores a desafiar as formas atuais de fazer as coisas para buscar melhorias (comportamento inovador) (NG, 2017). O líder transformacional dá aos seus seguidores um significado e razões para investir esforços em suas atividades (GRANT, 2012). É mais provável que os seguidores de líderes transformacionais endossem a missão organizacional (CAILLIER, 2016; COLBERT, KRISTOF-BROWN, BRADLEY \& BARRICK, 2008). Os efeitos positivos da liderança transformacional existem não apenas no nível individual, mas também nos níveis de equipe, unidade e organização (SEARLE \& BARBUTO, 2013).

Cavazotte, Moreno e Lasmar (2020) mostraram em um estudo empírico realizado com equipes de uma empresa de call-center que, mesmo em contextos onde as tarefas não são intrinsecamente motivadoras e cujas recompensas de desempenho são escassas, a liderança transformacional é um fator importante para motivar as equipes de atendimento ao cliente e, assim, promover a satisfação do cliente e o desempenho organizacional.

Com base nas evidências e argumentos expostos nesta seção propõe-se que: Hla: A liderança transformacional está positivamente associada ao desempenho financeiro de equipes de projeto (lucro).

H1b: A liderança transformacional está positivamente associada ao desempenho do projeto na ótica do cliente (satisfação dos clientes).

H1c: A liderança transformacional está positivamente associada à capacidade da equipe de criar novos projetos junto ao cliente (DNA empreendedor).

A liderança transformacional não exclui a importância da liderança transacional (BASS, 1999). Dinh et al. (2014) ressaltam a importância de diferentes estilos de liderança para influenciar resultados organizacionais. Líderes transacionais enfatizam padrões de trabalho, atribuições e tarefas orientadas para os objetivos e tendem a se concentrar em recompensas organizacionais para influenciar o desempenho de seus subordinados e equipe. A liderança transacional enfatiza a troca que ocorre entre um líder e seus seguidores. Essa troca envolve direção do líder ou discussão mútua com os seguidores sobre os requisitos para se alcançar os objetivos desejados, podendo a recompensa ser psicológica ou materialmente gratificante; por outro lado, insuficiência no desempenho acarretará 
decepção, desculpas, insatisfação e punição também de caráter psicológico ou material. Se a transação ocorre e as necessidades de líder e seguidores são cumpridas e se o líder tem o poder formal ou informal para fazê-lo, tende a reforçar o desempenho bem-sucedido (BASS; BASS, 2009). Na perspectiva de liderança transacional, o comportamento do líder é direcionado para o acompanhamento e orientação do subordinado, distribuição de recompensas, no papel de educador e motivador da equipe e no relacionamento com as pessoas, visando atingir as metas e objetivos organizacionais (BASS, 1985). O foco principal de líderes transacionais é nos objetivos, esclarecendo a ligação entre desempenho e recompensas, bem como no feedback construtivo para manter os seguidores na tarefa (BASS, 1985; JUNG \& AVOLIO, 1999). Portanto, acreditase que, a exemplo da liderança transformacional, o estilo de liderança transacional também exerça influência no desempenho, principalmente através da recompensa contingente.

Com base nas evidências e nos argumentos apresentados, propõe-se que:

H2a: A liderança transacional está positivamente associada ao desempenho financeiro de equipes de projeto (lucro).

H2b: A liderança transacional está positivamente associada ao desempenho do projeto na ótica do cliente (satisfação dos clientes).

H2c: A liderança transacional está positivamente associada à capacidade da equipe de criar novos projetos junto ao cliente (DNA empreendedor).

\subsection{3}

\section{Liderança Instrumental}

Várias perspectivas de liderança têm sido propostas por pesquisadores acadêmicos, sendo a teoria da liderança de Bass (1985) - que reúne a liderança transformacional, transacional e laissez-faire no conjunto que compõem o modelo de alcance total ("full-range model") - uma das mais pesquisadas (ANTONAKIS, BASTARDOZ, LIU, \& SCHRIESHEIM, 2014). Enquanto os líderes transformacionais inspiram seus seguidores com uma visão de futuro positiva e baseada em valor, os líderes transacionais confiam em transações quid-pro-quo claramente definidas. No entanto, a ideia de que estas classes de comportamento de liderança sejam suficientes para compreender os fenômenos desse campo foi 
contestada (GREGERSEN, VINCENT-HÖPER, \& NIENHAUS, 2014; JUDGE, PICCOLO, \& ILIES, 2004; YUKL, 2009).

O modelo de Bass (1985) tem o mérito de integrar três perspectivas de liderança em um modelo único, e durante muito tempo foi considerado um modelo completo. Porém, embora o trabalho de Bass (1985) possua bases sólidas e tenha gerado muitas pesquisas (JUDGE \& PICCOLO, 2004), sua teoria não explica alguns aspectos importantes da liderança (ANTONAKIS \& HOUSE, 2014; ROWOLD, 2014).

Além da influência transformacional e transacional, líderes efetivos também devem garantir que as organizações se adaptem ao ambiente externo e usem os recursos de maneira eficiente (FLEISHMAN et al., 1991; HACKMAN \& WAGEMAN, 2005; MORGESON, 2005; MUMFORD, 2006). Os líderes atuais devem formular uma estratégia que explique como a visão pode ser realizada e quais recursos são necessários para que isso aconteça (HOOIJBERG, HUNT, ANTONAKIS, BOAL, \& LANE, 2007; NADLER \& TUSHMAN, 1990). No entanto, a teoria da liderança transformacional não inclui comportamentos de liderança relacionados à obtenção de informações sobre mercados e nem comportamentos estratégicos (ROWOLD, 2014).

Rowold (2014), sugere a necessidade de extensões do paradigma transformacional-transacional para uma descrição mais abrangente dos comportamentos dos líderes nas organizações atuais. Antonakis \& House (2014), utilizaram a teoria de liderança funcional (MORGESON, DERUE \& KARAM, 2010) e pragmática (MUMFORD, 2006) para destacar a importância da liderança instrumental e como ela pode complementar a teoria de alcance total ("full-range theory") de Bass. As funções descritas na taxonomia de Morgeson et al. (2010) são similares às identificadas por Antonakis \& House (2002). Morgeson et al. (2010) identificaram funções de líder que atualmente não são consideradas no modelo de alcance total: (i) estruturação e planejamento estratégico, (ii) fornecimento de direção e recursos, (iii) monitoramento do ambiente externo e (iv) monitoramento do desempenho e a provisão de feedback.

Antonakis e House (2002) argumentam que líderes devem empreender certas atividades que não são baseadas em criar uma visão, fornecer desafio, apoio social ou encorajamento, nem estão vinculadas ao cumprimento de obrigações transacionais. Essas atividades, não tratadas anteriormente na teoria, tem a ver 
com uma classe de liderança que representa funções estratégicas e de facilitação do trabalho, chamada de liderança instrumental. De acordo com Antonakis e House (2014), uma teoria "mais completa" ("fuller") da perspectiva de abrangência total (“full-range”), deve incluir aspectos de facilitação do trabalho e liderança estratégica, bem como liderança transacional e transformacional.

Assim, Antonakis e House (2014) definem liderança instrumental como a aplicação de conhecimento especializado do líder no monitoramento do ambiente e do desempenho; e a implementação de soluções estratégicas e táticas. Estrategicamente, os líderes monitoram o ambiente externo e definem estratégias e metas. Do ponto de vista da facilitação do trabalho do seguidor, os líderes fornecem orientação e recursos, monitoram o desempenho e fornecem feedback (MORGESON et al., 2010). Antonakis e House (2014) definiram duas principais categorias de liderança instrumental: (i) liderança estratégica e (ii) facilitação do trabalho do seguidor. A liderança estratégica influencia o desempenho organizacional indiretamente, por meio de ações e decisões tomadas pelo líder e seus seguidores (ANTONAKIS \& HOUSE, 2002). Duas dimensões compõem a liderança estratégica conforme a Figura 1, (i.i) monitoramento ambiental e (i.ii) formulação e implementação de estratégias.

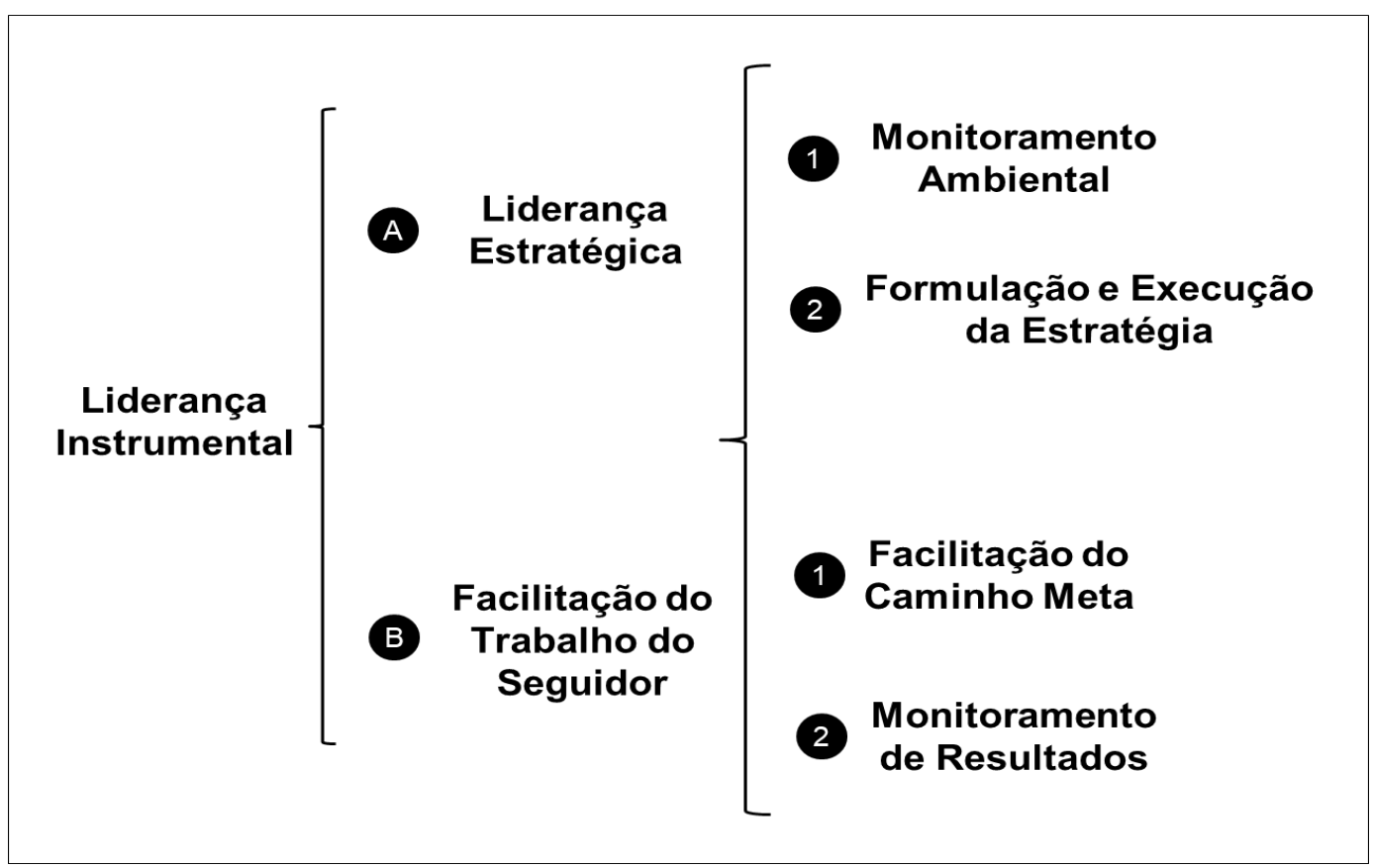

Figura 1 - Liderança instrumental e suas dimensões Fonte: Elaborado pelo autor 


\section{Monitoramento ambiental}

Líderes são responsáveis pelo monitoramento de ambientes internos e externos para: (a) identificar oportunidades de crescimento e desenvolvimento e (b) fornecer condições de trabalho adequadas para seus seguidores. De acordo com Antonakis e House (2002), essa classe de comportamento de liderança é chamada de monitoramento ambiental.

\section{Formulação e implementação de estratégias}

Após o monitoramento ambiental, líderes formulam uma estratégia para o grupo de trabalho e investem tempo e recursos para implementar a estratégia, o que inclui a criação de políticas e o detalhamento de sub estratégias (ANTONAKIS \& HOUSE, 2002).

Quanto à facilitação do trabalho do seguidor - segunda categoria da liderança instrumental - esta é proposta para influenciar o desempenho do seguidor diretamente (ANTONAKIS \& HOUSE, 2002) e a exemplo da primeira categoria da liderança instrumental, também possui duas dimensões: (ii.i) facilitação do caminho meta e (ii.ii) monitoramento de resultados.

\section{Facilitação do caminho meta (path-goal facilitation)}

Um aspecto importante da liderança eficaz é ajudar os seguidores nos problemas do dia-a-dia, removendo obstáculos, fornecendo recursos e esclarecendo como os seguidores podem atingir suas respectivas metas relacionadas ao trabalho. Em outras palavras, os líderes são proativos no sentido de ajudar os seguidores a entender o caminho em direção ao objetivo. A experiência de um líder é um pré-requisito importante para a facilitação do caminho-objetivo. Deve-se notar que esta classe de comportamentos de liderança é muito direta (suporte prático) e que a facilitação de caminho-objetivos (foco no suporte cognitivo e prático) é distinta do apoio individualizado (foco no apoio emocional).

\section{Monitoramento de resultados}

Antonakis e House (2002) definiram o monitoramento de resultados como fornecimento - tempestivo - de feedback instrumental aos seguidores, que é exclusivamente (a) relevante para a tarefa atual (e.g., "Como erros podem ser 
evitados?") e (b) construtivo. Assim, o monitoramento de resultados é dado durante o processo de trabalho e não após o respectivo objetivo ter sido atingido (ou não).

Por ser relativamente recente, ainda existem poucos estudos empíricos sobre a perspectiva de liderança instrumental. Antonakis e House (2014), analisaram a correlação entre liderança instrumental e desempenho subjetivo, enquanto, Rowold (2014), analisou a correlação entre liderança instrumental e desempenho objetivo. Líderes instrumentais levam suas equipes a alcançar resultados superiores na medida em que sua experiência na formulação e execução de estratégias permite facilitar o caminho a ser percorrido por seus seguidores no alcance de seus objetivos e dos objetivos organizacionais. A liderança instrumental representa as funções estratégicas e de facilitação do trabalho do seguidor, essenciais para o desempenho sustentável da organização (ANTONAKIS \& HOUSE, 2002; 2004). Essa classe altamente proativa de liderança não se baseia em ideais ou apelos emocionais, nem em abordagens transacionais, mas no suporte prático e facilitação do caminho que o líder fornece aos seus seguidores. O comportamento do líder instrumental é focado no direcionamento, suporte e provisionamento de recursos, eliminando obstáculos para a obtenção de resultados. Ao monitorar resultados e fornecer feedback construtivo, líderes instrumentais reforçam as crenças de autoeficácia do seguidor e contribuem para alcançar a meta do liderado. A liderança instrumental é autêntica na medida em que é vital para promover o desempenho organizacional sustentável (ROWOLD, 2014).

Torna-se relevante a produção de estudos empíricos que abordem os efeitos positivos da liderança instrumental no desempenho.

Com base nessas evidências e argumentos propõe-se que:

H3a: A liderança instrumental está positivamente associada ao desempenho financeiro de equipes de projeto (lucro).

H3b: A liderança instrumental está positivamente associada ao desempenho do projeto na ótica do cliente (satisfação dos clientes).

H3c: A liderança instrumental está positivamente associada à capacidade da equipe de criar novos projetos junto ao cliente (DNA empreendedor). 


\subsection{4 \\ Empoderamento e Liderança Empoderadora}

\subsubsection{1 Empoderamento}

Segundo Conger (1989), indivíduos se consideram poderosos quando sentem que podem lidar adequadamente com as demandas ambientais - situações, eventos e pessoas com as quais se confrontam - e se sentem impotentes quando são incapazes de lidar com essas demandas. $\mathrm{O}$ empoderamento pode ser descrito como o ato de fortalecer as crenças de um indivíduo em seu senso de eficácia, i.e., não se trata apenas de um conjunto de ações externas; é um processo de mudar as crenças internas das pessoas (CONGER, 1989).

De acordo com Bandura (1977), qualquer prática gerencial que aumente o senso de autodeterminação de um indivíduo, tenderá a fazer com que esse indivíduo se sinta mais poderoso. $\mathrm{O}$ autor conceituou a noção de crenças de auto eficácia e seu papel no sentido de poder pessoal de um indivíduo no mundo, e identificou quatro meios de fornecer informações de "empoderamento" para os outros: (i) através de apoio emocional positivo durante experiências associadas a estresse e ansiedade, (ii) através de palavras de encorajamento e persuasão positiva, (iii) observando outras pessoas bem sucedidas na tarefa e (iv) por realmente experimentar o domínio de uma tarefa com sucesso (a fonte mais efetiva).

O empoderamento dos membros de uma organização torna-se mais relevante em determinados contextos. É importante identificar condições dentro das organizações que possam promover algum senso de "impotência". Existem circunstâncias que podem diminuir os sentimentos de autoeficácia. Nesses casos, os subordinados costumam sentir uma falta de controle sobre sua situação imediata (por exemplo, uma grande mudança ou reorganização), ou sem a capacidade, os recursos ou mesmo a descrição necessária para realizar uma tarefa (por exemplo, o desenvolvimento de habilidades novas e complexas para a introdução de um novo processo tecnológico). Em ambos os casos, essas experiências maximizam sentimentos de inadequação e baixa autoconfiança, aparentando diminuir a motivação e a eficácia. Conger e Kanungo (1988) identificaram os fatores organizacionais mais comuns que afetam essas crenças de 
auto eficácia ou poder pessoal e contribuem para o sentimento de impotência, conforme a Tabela 1.

Tabela 1 - Fatores que levam ao potencial estado de impotência

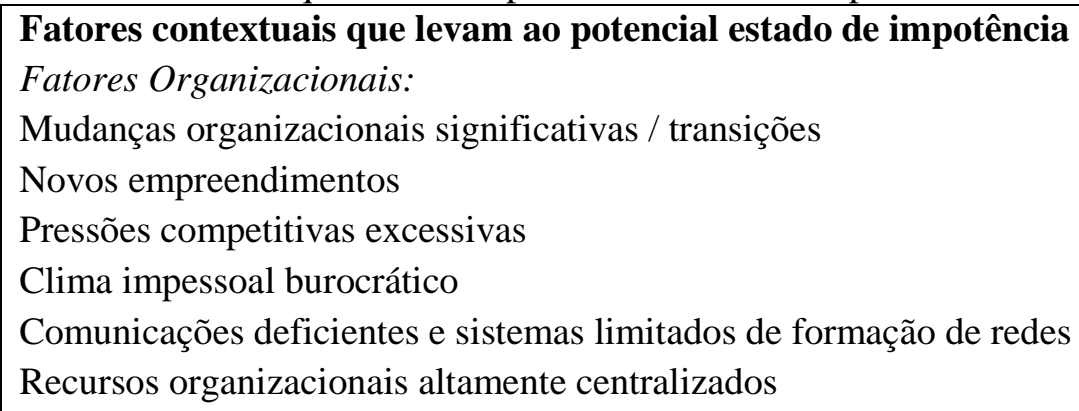

Estilo de Supervisão:

Autoritário (controle alto)

Negativismo (ênfase em falhas)

Falta de razão para ações / consequências

Sistemas de Recompensa:

Alocações arbitrárias de recompensa

Baixo valor de incentivo de recompensas

Falta de recompensas baseadas em competência

Falta de recompensas baseadas em inovação

Projeto de trabalho:

Falta de clareza de papel

Falta de treinamento e suporte técnico

Objetivos não realistas

Falta de autoridade / discrição apropriada

Baixa variedade de tarefas

Participação limitada em programas, reuniões e decisões que têm um impacto direto no desempenho do trabalho

Falta de recursos apropriados / necessários

Falta de oportunidades de formação de redes

Rotinas de trabalho altamente estabelecidas

Muitas regras e diretrizes

Baixa oportunidade de avanço

Falta de objetivos / tarefas significativas

Contato limitado com a gerência sênior

Fonte: Adaptado de Conger \& Kanungo (1988)

Conger e Kanungo (1988) descreveram o processo de empoderamento envolvendo várias etapas. Os gerentes podem começar por identificar se existem condições que levam a um estado psicológico de impotência em suas próprias organizações. Além disso, os gerentes que assumem novas responsabilidades 
devem conduzir um diagnóstico organizacional que identifique claramente sua situação atual e possíveis problemas e suas causas. Uma vez identificadas as condições que contribuem para sentimentos de impotência, as práticas gerenciais de empoderamento podem ser usadas para fornecer informações de auto eficácia aos subordinados. Contudo, ao aplicar essas práticas, é imperativo que os gerentes ajustem suas ações de acordo com o contexto em questão. Por fim, é necessário que os gestores de níveis mais elevados estabeleçam metas desafiadoras e atraentes para suas organizações. Este é um componente necessário da liderança eficiente e empoderadora. A Figura 2 ilustra o processo de empoderamento.

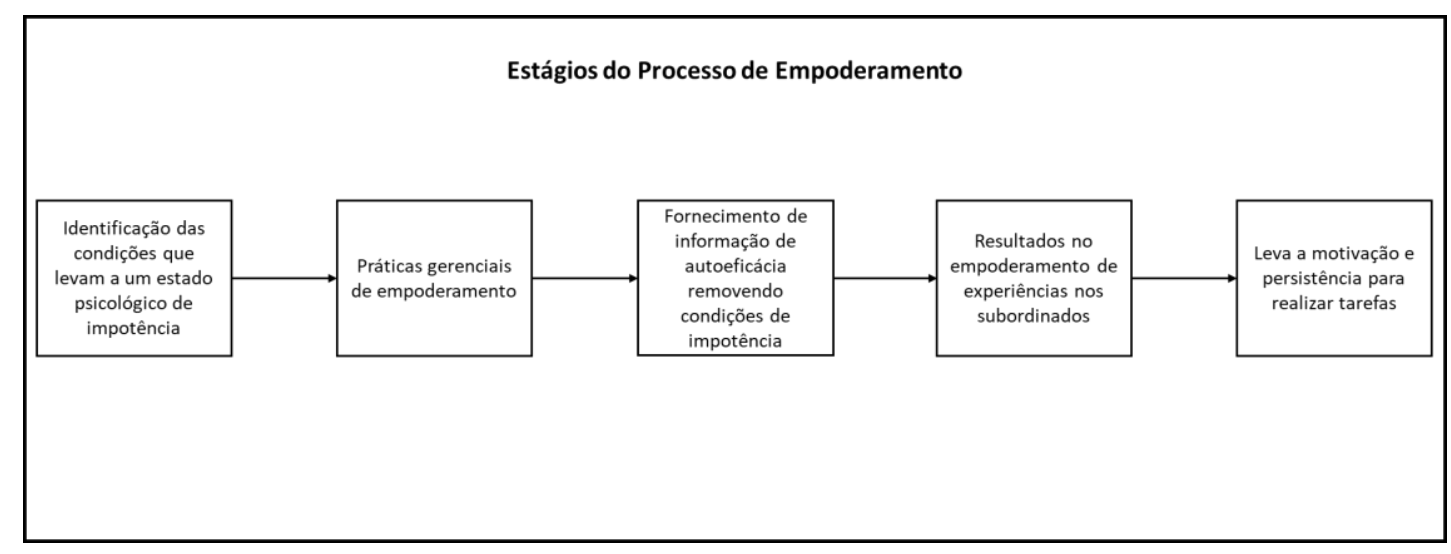

Figura 2 - Processo de empoderamento

Fonte: Adaptado de Conger \& Kanungo (1988)

Após revisarem pesquisas relevantes, Thomas e Velthouse (1990) argumentaram que o empoderamento é multifacetado e que sua essência não pode ser captada por um único conceito. Os autores definiram empoderamento de maneira mais ampla, como o aumento da motivação intrínseca da tarefa, manifestada em um conjunto de quatro cognições que refletem para um indivíduo o seu papel: (i) significado, (ii) competência, (iii) autodeterminação e (iv) impacto.

\section{Significado}

Significado é o valor de uma meta ou propósito de trabalho, julgado em relação aos ideais ou padrões de um indivíduo. O significado envolve um ajuste entre os requisitos de um papel de trabalho e crenças, valores e comportamentos. 


\section{Competência}

Competência, ou autoeficácia, é a crença do indivíduo nas suas capacidades e habilidades. A competência é análoga às crenças de agência, domínio pessoal ou expectativa de desempenho de esforço.

\section{Autodeterminação}

Enquanto a competência é um domínio do comportamento, a autodeterminação é o sentimento de um indivíduo de ter escolha ao iniciar e regular as ações. A autodeterminação reflete a autonomia no início e continuação de comportamentos e processos de trabalho (por exemplo: decisões sobre métodos de trabalho, ritmo e esforço).

\section{Impacto}

Impacto é o grau em que um indivíduo pode influenciar resultados estratégicos, administrativos ou operacionais no trabalho. O impacto é diferente do locus de controle; enquanto o impacto é influenciado pelo contexto de trabalho, o locus interno de controle é uma característica de personalidade global que perdura entre as situações.

Juntas, essas quatro dimensões refletem uma orientação ativa para o papel de trabalho e formam um construto geral de empoderamento psicológico. A falta de uma dessas dimensões irá enfraquecer, mas não completamente eliminar, o grau total do sentimento de empoderamento (SPREITZER, 1995).

Algumas premissas gerais sobre o empoderamento devem ser explicitadas. Primeiro, o empoderamento não é um traço duradouro de personalidade generalizável entre as situações, mas sim um conjunto de cognições moldadas por um ambiente de trabalho (THOMAS \& VELTHOUSE, 1990). Segundo, o empoderamento deve ser interpretado como uma variável contínua, i.e., os indivíduos devem ser vistos como mais ou menos empoderados, ao invés de empoderados ou não. Terceiro, o empoderamento não é um construto generalizável para diversas situações, mas específico do ambiente de trabalho (SPREITZER, 1995). 


\subsubsection{2 Liderança Empoderadora}

A noção de empoderamento surge da necessidade de um conceito organizacional capaz de refletir a garantia da produtividade dos funcionários em relação às mudanças tecnológicas e comerciais que ocorriam tanto nos negócios quanto no setor público na década de 1980 (BARTUNEK \& SPREITZER, 2006; FERNANDEZ \& MOLDOGAZIEV, 2011; HILL \& HUQ, 2004). Tais mudanças levaram a uma maior orientação para os clientes, estruturas organizacionais mais flexíveis, achatadas, descentralizadas, bem como a melhorias na qualidade e eficiência para a maioria das organizações (AMUNDSEN \& MARTINSEN, 2014). A natureza do trabalho também mudou significativamente nas últimas décadas, tornando-se mais complexa e exigente cognitivamente (HUMPHREY, NAHRGANG, \& MORGESON, 2007), com trabalhadores extremamente qualificados e instruídos se tornando o núcleo de um segmento da força de trabalho em rápido crescimento (PARKER, WALL \& CORDERY, 2001).

Nesta mudança de cenário, a liderança "empoderadora" emergiu como uma forma particular de liderança, distinta de outras abordagens, como a diretiva, a transacional e a transformacional (PEARCE et al., 2003). Em sua essência, a liderança empoderadora envolve a transferência de poder da alta direção para trabalhadores com alta autonomia, capazes de tomar iniciativas e decisões sobre as atividades diárias (FORD \& FOTTLER, 1995). Em consequência, tais características de trabalho exigem formas particulares de liderança. Considerando que, em geral, a liderança é descrita como um processo de influenciar os outros (YUKL, 2010), empoderar é mais sobre dar influência do que ter influência.

A liderança empoderadora pode ser estudada a partir de duas diferentes perspectivas, mas que se complementam (SPREITZER \& DONESON, 2005). A primeira perspectiva foca nas ações do líder, que compartilha poder e dá mais responsabilidade e autonomia aos subordinados (KIRKMAN \& ROSEN, 1997; 1999), e concentra-se nas práticas gerenciais com base em uma perspectiva sócioestrutural, na qual os comportamentos de empoderamento de um líder desempenham um papel vital (CHEONG et al. 2018). Já a segunda perspectiva foca nas respostas dos subordinados ao empoderamento, em particular sob o ponto de vista da motivação (CONGER \& KANUNGO, 1988; KIRKMAN \& ROSEN; 
1997; 1999; THOMAS \& VELTHOUSE, 1990). Nesse sentido, Srivasta et al. (2006) definiram a liderança empoderadora como comportamentos pelos quais o poder é compartilhado com os subordinados e que elevam seu nível de motivação intrínseca.

$\mathrm{Na}$ perspectiva de liderança empoderadora, os seguidores possuem menor dependência do líder em comparação com as tradicionais formas de liderança, sendo assim, nessa perspectiva, a facilitação e o apoio à autonomia tornam-se características fundamentais (AMUNDSEN \& MARTINSEN, 2014). Em uma metanálise abrangente da literatura sobre o desenho de tarefas de trabalho (job design) de Humphrey e colaboradores (2007), verificou-se que a autonomia foi a única característica motivacional com relação significativa com o desempenho objetivo.

Além disso, pesquisas sobre o modelo da teoria de autodeterminação mostraram que um estilo gerencial de apoio à autonomia produz uma variedade de resultados positivos nos subordinados, incluindo avaliações de desempenho e motivação para tarefas (AMUNDSEN \& MARTINSEN, 2014). Outros estudos relevantes que destacam a importância da autonomia e da autodeterminação incluem a teoria comportamental de autogestão (e.g., THORENSON \& MAHONEY, 1974), a teoria da autoliderança (e.g., MANZ, 1986) e a teoria social cognitiva (e.g., BANDURA, 1986).

Amundsen e Martinsen (2014) sugerem que capacitar os líderes pode afetar a autonomia dos subordinados através de três processos de influência diferentes, mas relacionados entre si. O primeiro pode ser representado pela abordagem socio- estrutural clássica, que envolve o compartilhamento de poder e a delegação de responsabilidade e autoridade formais. Em segundo lugar, além de compartilhar o poder formal, os líderes devem apoiar a motivação dos subordinados para trabalhar de forma autônoma. Uma terceira maneira de influenciar a autonomia é promover o aprendizado e o desenvolvimento dos subordinados em suas funções de trabalho, incluindo a capacidade de liderar a si mesmos. Desta forma, os líderes podem capacitar os subordinados, dando-lhes autonomia através do poder de compartilhar, promover sua energia e esforço para lidar com a autonomia através do apoio à motivação e facilitar suas habilidades e competências para trabalhar de forma autônoma através do apoio ao desenvolvimento. 
Arnold et al. (2000) identificaram cinco dimensões-chave da liderança empoderadora: liderar pelo exemplo, tomada de decisão participativa, coaching, informar e mostrar preocupação individual. Segundo Ahearne et al. (2005), as dimensões da liderança empoderadora incluem: melhorar a significância do trabalho, fomentar a participação na tomada de decisões, expressar confiança no alto desempenho e fornecer autonomia das restrições burocráticas. De forma semelhante, Amundsen e Martinsen (2015) argumentam que as duas dimensões centrais da liderança empoderadora são: apoio à autonomia e apoio ao desenvolvimento.

Como a perspectiva de liderança empoderadora é baseada em conceitos relacionados ao suporte dos líderes, as semelhanças com outros conceitos de liderança estabelecidos são inevitáveis. Contudo, as características únicas de empoderamento diferenciam a liderança empoderadora de outras perspectivas de liderança que estão enraizadas em conceitos relacionados a suporte a líderes, como: liderança participativa, liderança transformacional/carismática, liderança ética, auto-liderança, troca entre líder e liderado (LMX), liderança compartilhada e teoria do caminho-objetivo (AMUNDSEN \& MARTINSEN, 2014; PEARCE \& SIMS JR, 2002; TEKLEAB, SIMS JR., YUN, TESLUK, \& COX, 2008).

A liderança participativa refere-se a comportamentos do líder que envolvem os seguidores na tomada de decisão conjunta e compartilham influência na tomada de decisões com os seguidores (ARMENAKIS, HARRIS, \& MOSSHOLDER, 1993; LAM, HUANG, \& CHAN, 2015). Embora os conceitos de liderança participativa e liderança empoderadora estimulem o envolvimento ativo de seguidores no processo de tomada de decisão, a liderança empoderadora reflete um conceito mais amplo e inclui a noção de tomada de decisão participativa dos seguidores como subdimensão (AHEARNE et al., 2005; ARNOLD et al., 2000). Os comportamentos do líder participativo são um aspecto necessário, mas não condição suficiente para o construto de liderança empoderadora.

Liderança transformacional refere-se a um conjunto de comportamentos de líder (composto de quatro dimensões anteriormente descritas - influência idealizada, motivação inspiradora, consideração individualizada e estímulo intelectual) focados em inspirar seguidores a compartilhar e perseguir uma visão e motivá-los a trabalhar pelo bem do grupo ou organização (BASS \& STEIDLMEIER, 1999; YAMMARINO \& BASS, 1990). Embora estudos 
empíricos anteriores tenham mostrado altas correlações entre liderança transformacional e liderança empoderadora (e.g., AMUNDSEN \& MARTINSEN, 2014), vários estudos apoiaram empiricamente a distinção entre liderança transformacional e liderança empoderadora (e.g., AMUNDSEN \& MARTINSEN, 2014; ARNOLD et al., 2000; PEARCE \& SIMS JR, 2002). Além disso, no que diz respeito à comparação de sub-dimensões específicas que compõem os construtos da liderança transformacional e da liderança empoderadora, as principais dimensões da liderança empoderadora se relacionam com o compartilhamento ou o fornecimento de autonomia aos seguidores e o seu envolvimento na tomada de decisões. Essas dimensões não estão incluídas nas dimensões que compõem a liderança transformacional (AHEARNE et al., 2005; ARNOLD et al., 2000).

A liderança ética enfoca principalmente a orientação dos líderes a respeito de fazer o que é certo, orientar os outros de maneira ética e recompensar os comportamentos éticos dos subordinados. Os líderes éticos transformam a responsabilidade de seus seguidores através de ações éticas (BROWN \& TREVIÑO, 2006; HASSAN, MAHSUD, YUKL, \& PRUSSIA, 2013; PALANSKI \& YAMMARINO, 2009). Embora possa ser desejável que os líderes tenham uma base ética, a liderança empoderadora é diferente do conceito de liderança ética, porque a orientação de um líder empoderador não está centrada em uma perspectiva ética, i.e., nem todos os líderes que são éticos são necessariamente líderes empoderadores.

Autoliderança é um conjunto de estratégias que um indivíduo usa para controlar e influenciar seus próprios comportamentos e ações, indicando que as pessoas olham dentro de si para descobrir as fontes de motivação e controle de seus estados e comportamentos cognitivos (MANZ \& SIMS JR., 1980). A liderança empoderadora é um conjunto de comportamentos de líderes destinados a aumentar a percepção e a confiança dos seguidores em relação ao trabalho, participação e autonomia. Em contraste, a autoliderança é um conjunto de comportamentos ou estratégias individuais que os empregados exercem sobre si mesmos para controlar seus próprios comportamentos. Dessa maneira, capacitar os comportamentos dos líderes pode funcionar como um dos precursores que influenciam a autoliderança de seus seguidores. 
A teoria LMX destaca a qualidade do relacionamento entre o líder e o membro do grupo e enfoca os relacionamentos diferenciados de líder e membros dentro de um grupo e a qualidade geral desses relacionamentos (CHEONG et al., 2019). Embora vários estudos empíricos tenham mostrado altas correlações entre a LMX e a liderança empoderadora (e.g., AMUNDSEN \& MARTINSEN, 2014; HASSAN et al., 2013), trata-se de conceitos distintos (CHEONG et al., 2019). Estudos anteriores apoiaram empiricamente a distinção entre LMX e liderança empoderadora (e.g., AMUNDSEN \& MARTINSEN, 2014; TEKLEAB et al., 2008).

A liderança compartilhada é uma abordagem coletivista, que vê a liderança como uma responsabilidade compartilhada e distribuída entre os membros de uma equipe (YAMMARINO, SALAS, SERBAN, SHIRREFFS, \& SHUFFLER, 2012). Embora a noção básica de compartilhar poder seja parte dos dois conceitos, em contraste com a liderança compartilhada, a liderança empoderadora diz respeito ao comportamento específico de líderes para compartilhar poder e alocar mais autonomia e responsabilidades a seguidores, equipes ou coletivos. Em termos de nível de análise, a liderança compartilhada é desenvolvida e estudada nos níveis de análise de grupo ou coletiva e tem sido considerada um fenômeno principalmente nesses dois níveis (CARSON, TESLUK, \& MARRONE, 2007; PEARCE \& SIMS JR, 2002; YAMMARINO et al., 2012), enquanto que a maioria dos estudos sobre liderança empoderadora é focada e conduzida nos níveis de análise individual ou de grupo (CHEONG et al., 2019).

A teoria de liderança do caminho-objetivo é uma referência teórica sobre as relações entre os comportamentos orientadores da tarefa e da pessoa (perspectiva do líder) e motivação e satisfação dos seguidores e suas características (perspectiva do seguidor), além de várias condições situacionais sob as quais tais relacionamentos serão eficazes dentro de um quadro diádico (HOUSE, 1971, 1996). Na formulação mais recente, House (1996) escalou a teoria do caminhometa para o nível de análise do grupo, mas não forneceu dados sobre essa noção. Esta meta-teoria, que enfatiza a integração de vários tipos de comportamentos do líder, diferenças individuais dos seguidores e contextos de tarefas simultaneamente para abordar a eficácia da liderança, é diferente do conceito de liderança empoderadora, que é um estilo específico de comportamento do líder 
com o objetivo de aumentar a motivação interna dos seguidores via poder de compartilhar e fornecer mais autonomia (CHEONG et al., 2019).

Portanto, a liderança empoderadora merece a construção de um estudo de liderança independente (SHARMA \& KIRKMAN, 2015). A Tabela 2 ilustra a semelhança e diferenciação do espaço conceitual entre a liderança empoderadora e os construtos de liderança relacionados.

Tabela 2 - Distinção entre a liderança empoderadora e as construções de liderança relacionadas

\begin{tabular}{|c|c|c|}
\hline Categoria de liderança & Foco & $\begin{array}{l}\text { Dimensão comportamental } \\
\text { central }\end{array}$ \\
\hline 1. Liderança empoderadora & $\begin{array}{l}\text { Abordagem comportamental } \\
\text { para liderança }\end{array}$ & $\begin{array}{l}\text { Apoio de Tarefa/Relacional } \\
\text { Provisão de autonomia }\end{array}$ \\
\hline 2. Liderança participativa & $\begin{array}{l}\text { Abordagem comportamental } \\
\text { para liderança }\end{array}$ & $\begin{array}{l}\text { Tomada de decisão } \\
\text { participativa }\end{array}$ \\
\hline $\begin{array}{l}\text { 3. Liderança } \\
\text { transformacional/carismática }\end{array}$ & $\begin{array}{l}\text { Abordagem comportamental } \\
\text { para liderança }\end{array}$ & $\begin{array}{l}\text { Influência } \\
\text { idealizada/motivação } \\
\text { inspiradora }\end{array}$ \\
\hline 4. Liderança Ética & $\begin{array}{l}\text { Abordagem comportamental } \\
\text { para liderança }\end{array}$ & Orientação ética \\
\hline 5. Auto-liderança & $\begin{array}{l}\text { Estratégia comportamental do } \\
\text { indivíduo focal }\end{array}$ & \\
\hline 6. LMX & $\begin{array}{l}\text { Abordagem baseada em } \\
\text { relacionamentos para } \\
\text { liderança }\end{array}$ & \\
\hline 7. Liderança compartilhada & $\begin{array}{l}\text { Abordagem coletivista para } \\
\text { liderança }\end{array}$ & \\
\hline 8. Teoria do caminho-objetivo & Framework meta-teórico & \\
\hline
\end{tabular}

Fonte: Cheong et al. (2019).

As seções até aqui apresentadas no presente capítulo evidenciaram que a liderança pode ser exercida verticalmente (através de vetores de influência unidirecionais, líder->liderado, na tomada de decisão) ou de maneira mais horizontal e distribuída (através de vetores de influência multidirecionais, líder>liderado->líder), na tomada de decisão. A liderança vertical segundo as perspectivas transformacional, transacional e instrumental descreve indivíduos poderosos e às vezes carismáticos que tomam decisões estratégicas, principalmente por conta própria, e influenciam os outros a implementar essas decisões (PITELIS \& WAGNER, 2019). A liderança vertical pode facilitar a mudança organizacional rapidamente. Em contraste com a liderança vertical, a liderança horizontal pode levar a realização de papéis complementares, fazendo o grupo capaz de sobreviver à ausência de qualquer indivíduo. Em parte, isso pode ser alcançado através da troca de responsabilidades de liderança entre indivíduos diferentes de acordo com as exigências da situação (PITELIS \& WAGNER, 
2019). A sobreposição cria um grau de monitoramento mútuo, verificações e equilíbrios, menos presentes na liderança vertical. Isso também ajuda a preservação de boas práticas por um longo período. Além disso, a criação de contextos de apoio, nos quais os indivíduos escolhem como e onde focalizar suas energias, permite que a liderança emerja da organização em todos os níveis (UHLBIEN \& ARENA, 2018). Essa liderança emergente envolve funcionários na escolha de como dividir o tempo entre atividades orientadas ao alinhamento.

Independente da perspectiva de liderança, líderes precisam estruturar suas organizações para lidar de forma efetiva com mudanças e incertezas. Devem ser capazes de posicionar as organizações e as pessoas para enfrentar desafios complexos. $\mathrm{Na}$ atualidade, ações de liderança que potencializam a capacidade de uma organização se adaptar rapidamente e evoluir ao longo do tempo parecem imprescindíveis. Srivastava, Bartol e Locke (2006) associaram liderança empoderadora ao compartilhamento de conhecimentos e ideias em equipes, aspectos essenciais à efetiva gestão de processos, gestão do conhecimento e ao desempenho eficaz em negócios inovadores. Líderes empoderadores estimulam um nível crescente de desempenho profissional em suas equipes, o que se traduz em maior comprometimento com metas, motivação, empenho, criatividade e inovação (ZHANG \& BARTOL, 2010).

Com base nessas evidências e argumentos propõe-se que:

H4a: A liderança empoderadora está positivamente associada ao desempenho financeiro de equipes de projeto (lucro).

H4b: A liderança empoderadora está positivamente associada ao desempenho do projeto na ótica do cliente (satisfação dos clientes).

H4c: A liderança empoderadora está positivamente associada à capacidade da equipe de criar novos projetos junto ao cliente (DNA empreendedor).

Cada vez mais as pesquisas têm constatado que diferentes estilos de liderança influenciam positivamente o desempenho organizacional (AVOLIO \& BASS, 1988; BASS, 1990; PETTIGREW, 1987, LOWE et.al., 1996). A próxima seção articula as perspectivas de liderança aqui tratadas em um modelo integrado de competências de liderança. 


\subsection{5}

\section{Competências globais de liderança: integrando perspectivas}

Conforme demandado pelos principais autores do campo de estudos sobre liderança (ANTONAKIS \& DAY, 2017, DIHN et al. 2014), é necessário buscar uma integração das diferentes perspectivas sobre liderança existentes no campo. De acordo com Antonakis e Day (2017), somente através de esforços para consolidar as observações acumuladas no campo é que a pesquisa sobre liderança passará para o próximo nível, onde finalmente será possível construir e testar teorias mais gerais de liderança. Segundo os autores, pesquisas anteriores estabeleceram as bases para tais teorias. Os pesquisadores do campo de estudos sobre liderança precisam começar a articular como os diversos conceitos e descobertas empíricas podem ser associados, teorias aparadas e, em seguida, sintetizadas e integradas tanto dentro como entre as disciplinas (ANTONAKIS, 2017).

Assim, esta tese também propõe um modelo teórico-conceitual comtemplando as quatro perspectivas de liderança abordadas no referencial teórico (perspectivas transformacional, transacional, instrumental e empoderadora). O modelo formativo proposto se baseia nos aportes teóricos de teorias da motivação, aqui utilizadas para fundamentar os mecanismos através dos quais diferentes comportamentos do líder ressaltados pelas quatro perspectivas se somam para promover o desempenho de equipes de trabalho. Nesta seção serão apresentados os argumentos que fundamentam o modelo formativo, sustentados em perspectivas de motivação intrínseca e extrínseca.

Embora alguns autores acreditem que a motivação extrínseca possa funcionar em oposição à motivação intrínseca, ela também pode ter um efeito reforçador (KANFER, FRESER \& JOHNSON, 2017). Hennessey et al. (2015) argumentam que a motivação intrínseca e a motivação extrínseca podem combinar sinergicamente para gerar altos níveis de desempenho e satisfação pessoal. Esta tese compartilha esse entendimento.

Teoria e pesquisa empírica sugeriram que a motivação humana para o trabalho pode ser categorizada em dois tipos distintos: motivação intrínseca e motivação extrínseca (AMABILE, 1993). A primeira surge do valor intrínseco do trabalho para o indivíduo (como seu valor de interesse) e a segunda surge do 
desejo de obter alguns resultados (como recompensas) que são separados do trabalho em si. A motivação intrínseca é a motivação para fazer algo impulsionado pela experiência do fazer em si mesma, do que é inerente ao próprio fazer e sua subjetividade, pelo puro prazer da tarefa em si, enquanto a motivação extrínseca é a motivação para fazer algo como meio para atingir algum objetivo externo ou atender a alguma restrição imposta externamente (HENNESSEY et al., 2015).

A liderança é um processo indutor de objetivos, que ocorre entre um líder e um seguidor - ou grupos de seguidores - (ANTONAKIS \& DAY, 2017). Nesse sentido, pode se dizer que a motivação é um componente fundamental para que este processo de influência ocorra. Segundo Amabile (1993), a motivação dos funcionários costuma ser um problema central para líderes e gerentes. De acordo com a autora, é provável que funcionários desmotivados dediquem pouco esforço em seus empregos, evitem o máximo possível o local de trabalho, saiam da organização se houver oportunidade e produzam um trabalho de baixa qualidade. Por outro lado, é provável que os funcionários que se sentem motivados com relação ao trabalho sejam persistentes, criativos e produtivos, produzindo um trabalho de alta qualidade (AMABILE, 1993). A motivação para o trabalho afeta as habilidades que os indivíduos desenvolvem, os empregos e carreiras que buscam e a maneira pela qual alocam seus recursos (e.g., atenção, esforço, tempo e capital humano e social) para afetar a direção, intensidade e persistência de atividades durante o trabalho (KANFER et al., 2017).

Como os gerentes e líderes organizacionais desempenham um papel importante na determinação desses fatores que influenciam a motivação, eles devem entender e lidar efetivamente com a motivação humana, se quiserem liderar com sucesso suas equipes de trabalho e organizações.

$\mathrm{Na}$ perspectiva de liderança transformacional, é possível identificar uma série de comportamentos dos líderes que mobilizam componentes motivacionais intrínsecos, tais como forte senso de propósito, significado, o foco em desafios inerentes ao alcance da visão e em desafios à geração da solução de problemas (ANTONAKIS, 2012). Srivasta et al. (2006) definiram a liderança empoderadora como comportamentos pelos quais o poder é compartilhado com os subordinados e que elevam seu nível de motivação intrínseca. A perspectiva de liderança empoderadora também foca em ações dos líderes que mobilizam motivadores 
intrínsecos, como a facilitação (que estimula a experiência de maestria ou competência) e o apoio à autonomia (que estimula o senso de auto-determinação) (AMUNDSEN \& MARTINSEN, 2014).

A liderança transacional é baseada na autoridade burocrática e legitimidade dentro da organização. Na perspectiva de liderança transacional, o comportamento do líder é direcionado para o acompanhamento e orientação do subordinado, distribuição de recompensas, no papel de motivador da equipe e no relacionamento com as pessoas, visando atingir as metas e objetivos organizacionais. A teoria da expectativa de Vroom (1964), afirma que esforço, desempenho e recompensa estão ligados na motivação de um indivíduo. Já a teoria de Locke e Latham (1990), conhecida como "estabelecimento de metas", afirma que metas afetam o desempenho da tarefa de um indivíduo. Metas difíceis (mas atingíveis) conduzem a um desempenho superior ao de metas fáceis. De acordo com os autores, variáveis tais como prêmios e envolvimento do indivíduo no processo decisório influenciam o comportamento porque leva a escolha e ao comprometimento com uma meta difícil e o estabelecimento de metas influencia a escolha, o esforço e a persistência para descobrir mecanismos de atingir a meta. Líderes transacionais enfatizam padrões de trabalho, atribuições e tarefas orientadas para os objetivos, tendem a se concentrar na conclusão da tarefa e na disciplina do funcionário através de comportamentos que mobilizam motivadores extrínsecos, tais como recompensas organizacionais e definição de metas para influenciar o desempenho.

A liderança instrumental empreende atividades que tem a ver com funções estratégicas e de facilitação do trabalho (ANTONAKIS \& HOUSE, 2002). Assim como a perspectiva de liderança transacional, a perspectiva de liderança instrumental pode ser considerada uma perspectiva de liderança na qual o líder empreende ações que mobilizam a motivação extrínseca para influenciar o desempenho de seus seguidores. Na perspectiva de liderança instrumental, os líderes identificam estratégias e metas, bem como fornecem orientação, recursos e monitoram o desempenho (MORGESON et al., 2010).

Considerando-se os dois tipos de motivação humana para o trabalho (motivação extrínseca e motivação intrínseca) apresentados, as perspectivas de liderança abordadas no presente estudo (transformacional, transacional; empoderadora e instrumental) podem ser classificadas em dois diferentes grupos: 
(i) comportamentos de liderança que acionam mecanismos de motivação intrínsecos e (ii) comportamentos de liderança que acionam mecanismos de motivação extrínsecos, conforme a Tabela 3.

Tabela 3 - Perspectivas de liderança e mecanismos de motivação

\begin{tabular}{|c|c|c|}
\hline Perspectiva de Liderança & $\begin{array}{c}\text { Foco do Comportamento } \\
\text { do Líder }\end{array}$ & $\begin{array}{c}\text { Mecanismos de } \\
\text { Motivação Acionados }\end{array}$ \\
\hline Liderança transformacional & Propósito/Visão/Desafio & \multirow{2}{*}{ Intrínsecos } \\
\hline Liderança empoderadora & $\begin{array}{c}\text { Autonomia } \\
\text { Significado }\end{array}$ & \multirow{2}{*}{ Extrínsecos } \\
\hline Liderança instrumental & $\begin{array}{c}\text { Direção Estratégica } \\
\text { Monitoramento/Feedback }\end{array}$ & \\
\hline Liderança transacional & $\begin{array}{c}\text { Recompensas } \\
\text { Correção/Feedback }\end{array}$ & \\
\hline
\end{tabular}

Fonte: Elaborado pelo autor.

O modelo teórico-conceitual proposto por esta tese busca uma integração das quatro diferentes perspectivas sobre liderança apresentadas (perspectivas transformacional, transacional, instrumental e empoderadora), com base nas teorias da motivação elencadas. Trata-se, portanto, de um modelo formativo, no qual se propõe que os diferentes comportamentos do líder ressaltados pelas quatro perspectivas se somam para formar competências globais de liderança, conforme as seguintes proposições:

P1: Mecanismos de motivação intrínsecos são formados pelas ações transformacionais de liderança.

P2: Mecanismos de motivação intrínsecos são formados pelas ações empoderadoras de liderança.

P3: Mecanismos de motivação extrínsecos são formados pelas ações instrumentais de liderança.

P4: Mecanismos de motivação extrínsecos são formados pelas ações transacionais de liderança.

P5: Competências globais de liderança são formadas pelas ações de liderança que mobilizam mecanismos de motivação intrínsecos.

P6: Competências globais de liderança são formadas pelas ações de liderança que mobilizam mecanismos de motivação extrínsecos. 
A Figura 3 resume as proposições apresentadas nesta seção.

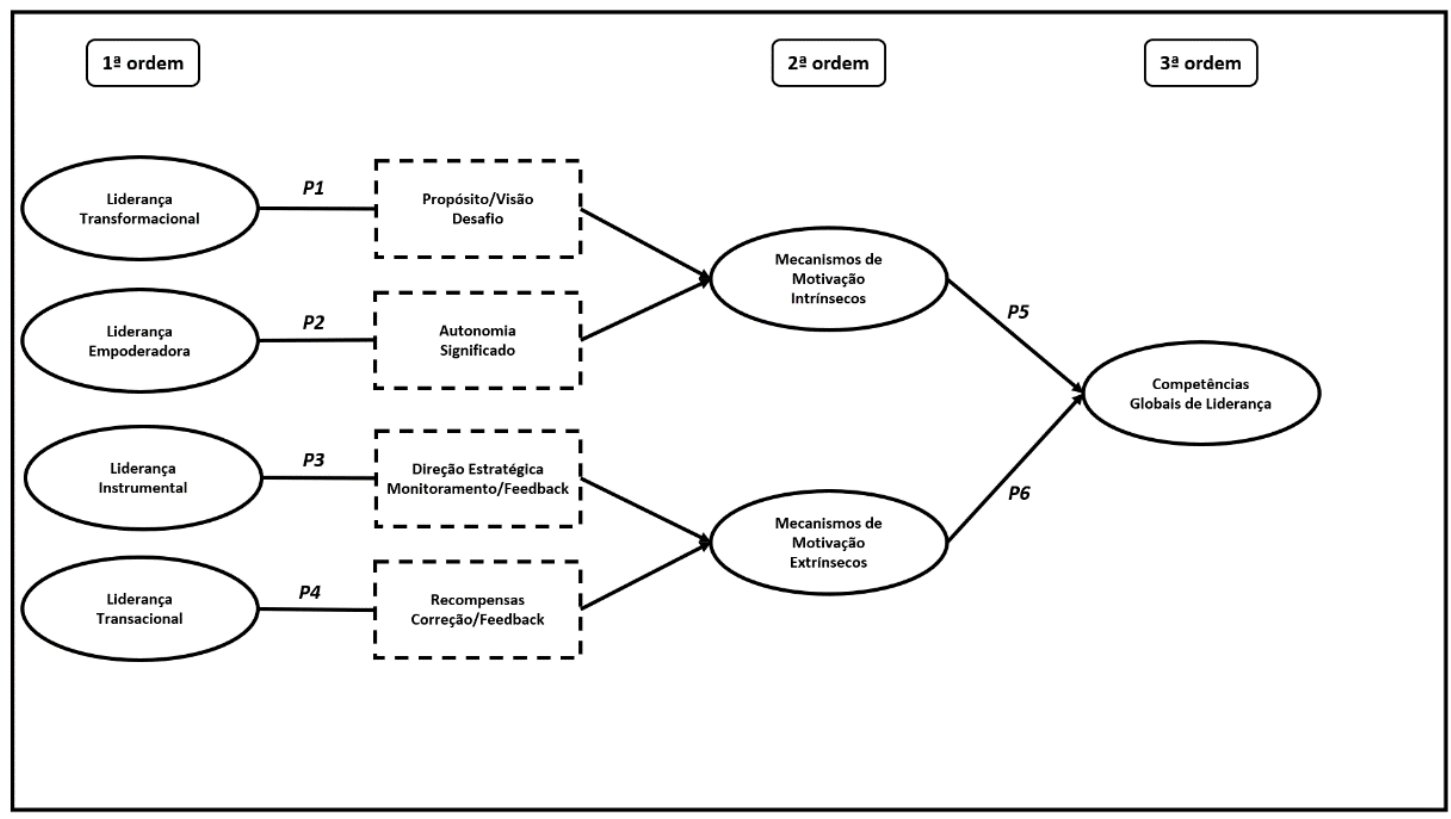

Figura 3 - Proposições de pesquisa. Fonte: Elaborado pelo autor.

A literatura sobre capacidades dinâmicas aborda questões fundamentais sobre como as empresas desenvolvem as habilidades e competências que lhes permitem competir e obter uma vantagem competitiva duradoura. Zahra et al. (2006) propuseram que a liderança desempenha um papel fundamental no desenvolvimento dessas capacidades dinâmicas. As próximas seções deste capítulo apresentam conceitos de estratégia relevantes para a apresentação do conteúdo relacionado as capacidades dinâmicas e para o desenvolvimento desta pesquisa.

\section{2.}

\section{Estratégia}

\subsection{1.}

\section{Estratégia e o Processo de Administração Estratégica}

O termo estratégia tem diferentes significados e depende da interpretação de cada leitor ou cultura organizacional. Segundo Quinn (1980), a estratégia seria o padrão ou plano que integra as principais metas, políticas e sequências de ação em um todo coeso. De forma mais restrita, Andrews (1971) distingue estratégia corporativa de estratégia de negócios. O autor define estratégia corporativa como o padrão de decisões de uma empresa que determina e revela seus objetivos, 
define as principais políticas e planos para alcançar esses objetivos e define o alcance dos negócios que a empresa deve seguir, o tipo de economia e organização humana que é ou pretende ser, e a natureza da contribuição econômica e não econômica que pretende gerar para os stakeholders. Ainda de acordo com o autor, enquanto a estratégia corporativa se aplica a toda a empresa, a estratégia de negócios define a escolha do produto ou serviço de negócios individuais dentro da empresa.

A estratégia de uma empresa pode ser compreendida como a sua teoria sobre como obter vantagens competitivas, e é baseada em suposições e hipóteses a respeito de como a competição no setor, no qual a empresa está inserida, irá se desenvolver; quanto mais acuradas essas hipóteses e suposições, maior a probabilidade de se obter vantagens competitivas (BARNEY, 2014; BARNEY \& HESTERLY, 2017). Desta forma, pode se dizer que a estratégia é o caminho que a empresa irá seguir para chegar aos seus objetivos. Uma estratégia, quando bem formulada, ajuda na organização e na alocação de recursos baseadas nas competências, na dinâmica do ambiente e nos movimentos contingentes de seus concorrentes (QUINN, 1980).

Não é fácil saber se a estratégia escolhida e seguida pela empresa é a mais eficiente, mas é necessário escolher a estratégia da empresa de forma cuidadosa e sistemática; acompanhar o processo de administração estratégica tende a reduzir a probabilidade de se cometer erros (BARNEY \& HESTERLY, 2017). O processo de administração estratégica consiste de uma série de decisões estratégicas individuais que devem ser integradas pela organização, de forma a estabelecer uma estratégia global. Trata-se de um conjunto de análises e escolhas sequenciais que possibilitam o aumento da probabilidade de escolha de uma estratégia capaz de gerar vantagens competitivas para a organização (BARNEY, 2014). Segundo Barney \& Hesterly (2017), os componentes do processo de administração estratégica são: definição da missão, estabelecimento de objetivos, análise do ambiente (externo e interno), escolha da estratégia, implementação da estratégia, tendo como consequência esperada, a geração de vantagem competitiva. O processo de administração estratégica pode ser exemplificado na Figura 4. 


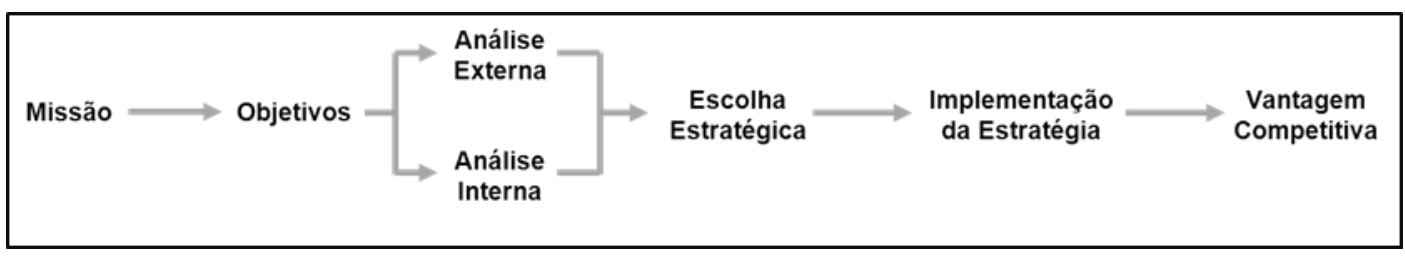

Figura 4 - Etapas do processo de administração estratégica

Fonte: Barney \& Hesterly (2017).

\subsection{2.}

\section{Vantagem Competitiva e o Processo de Criação de Valor}

O processo de administração estratégica tem como consequência esperada a geração de vantagem competitiva. Brandenburger \& Stuart (1996) definem vantagem competitiva como o intervalo de valor criado entre a disposição a pagar pelo cliente e o custo de oportunidade dos fornecedores. Em geral, uma empresa possui vantagem competitiva ao conseguir gerar maior valor econômico que seus concorrentes. Segundo Barney (2014), valor econômico é a diferença entre os benefícios percebidos por um cliente ao comprar um de seus produtos ou serviços e o custo econômico desse produto ou serviço. Desta forma, o tamanho da vantagem competitiva seria a diferença entre o valor econômico que uma empresa é capaz de criar e o valor econômico que suas rivais são capazes de criar (BARNEY, 2014).

O valor econômico gerado por uma empresa pode ser maior do que o de suas concorrentes, tanto por conseguir gerar maiores benefícios percebidos para seus clientes, quanto por gerar menores custos. A aferição de vantagem competitiva dependerá do contexto ao qual a empresa estiver inserida e das suas relações em uma cadeia vertical - que envolve fornecedor, empresa e cliente (ADEGBESAN, 2009; ADNER \& ZEMSKY, 2006). Em função da dinâmica dessa cadeia vertical, isto é, dependendo das interações com fornecedores e clientes, a empresa pode criar mais valor e ampliar as fronteiras da disposição a pagar e o custo de oportunidade (BRITO \& BRITO, 2012). Aspectos dinâmicos e sociais influenciam a forma com que o valor criado será reconhecido por cada um dos atores envolvidos (BLYLER \& COFF, 2003).

Brito \& Brito (2012) atentam que valor criado não é necessariamente valor apropriado; enquanto o valor criado é definido pelo custo de oportunidade e pela disposição a pagar, preço e custo definem o valor apropriado, conforme a Figura 5 . 


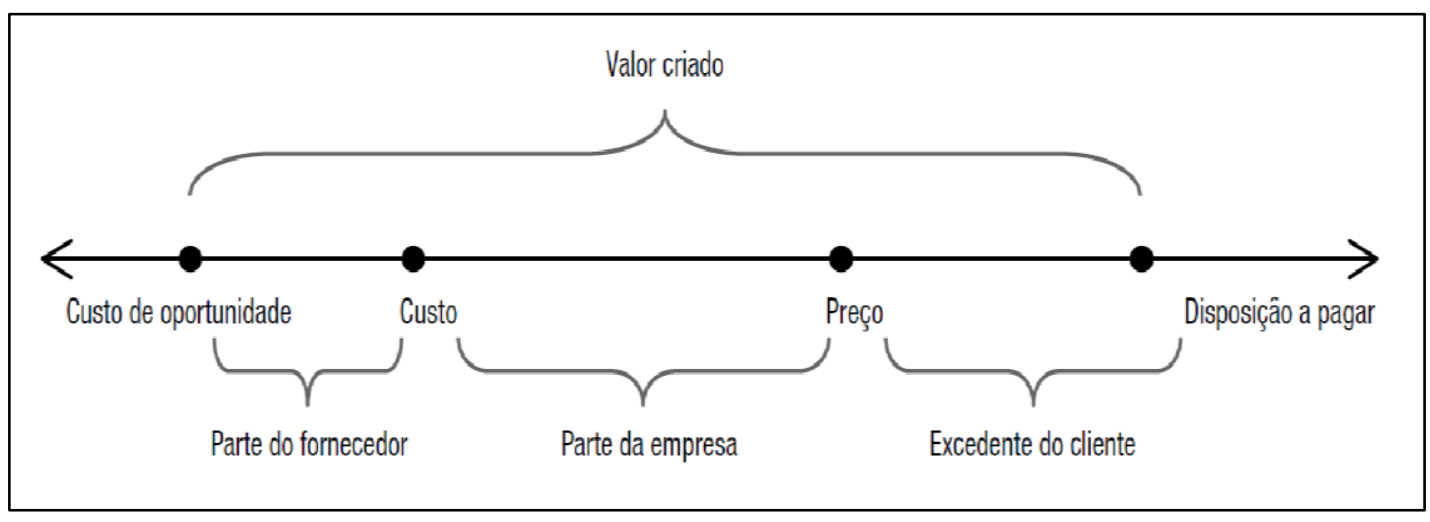

Figura 5 - Valor apropriado versus valor criado.

Fonte: Brito \& e Brito (2012).

Pode-se dizer que a manifestação mais direta da criação de valor auferida pela empresa é o lucro (BRITO \& BRITO, 2012). Contudo, existem outras implicações ligadas à criação de valor (LEPAK, SMITH \& TAYLOR, 2007). A diferença entre a disposição a pagar do cliente e o preço cobrado do produto ou serviço é chamada de excedente do cliente. Quando gera maior excedente para seus clientes, a empresa pode explorar a diferença de preço entre seus produtos e a média do mercado, cobrando um prêmio por isso (NEWBERT, 2008). A empresa com vantagem competitiva também pode escolher manter a paridade de preços com seus concorrentes, obtendo a preferência dos compradores, de forma a expandir a sua participação no mercado (CHATAIN, 2011; PRIEM, 2007). Dessa forma, o excedente do cliente é relevante para o desempenho da empresa, sendo apropriado pela empresa como lucro ou não. Na negociação com os demais stakeholders (fornecedores, colaboradores, gestores, dentre outros) são definidos os valores apropriados por cada um deles (ADEGBESAN, 2009; COFF, 1999; LIPPMAN \& RUMELT, 2003). Cada stakeholder é capaz de se apropriar de todo o valor contribuído no processo. Contudo, a diferença de contexto entre os atores influenciará a percepção de valor e a habilidade de negociação de cada um (ADEGBESAN, 2009; LIPPMAN \& RUMELT, 2003). A apropriação de valor é norteada, tanto na busca pelo lucro, quanto por interesses na construção e manutenção de parcerias e alianças, que auxiliam no desempenho operacional da empresa, gerando inovação e qualidade, além de impactar na disposição a pagar (COFF, 2010). 


\subsection{3. \\ Capacidades Dinâmicas}

Saber como as organizações geram e sustentam vantagens competitivas é a principal questão no campo da gestão estratégica (RUMELT, SCHENDEL, \& TEECE, 1994; TEECE, PISANO \& SHUEN, 1997). Para responder a essa questão é necessário analisar as fontes de criação de valor e retenção (de conhecimento) das organizações. O campo teórico da estratégia está repleto de análises (no nível da empresa) para sustentar e proteger a vantagem competitiva das organizações (TEECE et al., 1997). Em seu artigo seminal sobre capacidades dinâmicas, Teece et. al (1997) identificam três abordagens ou paradigmas referentes às fontes de vantagem competitiva. A abordagem das forças competitivas proposta por Porter (1989) diz respeito às ações que uma organização pode lançar mão para se posicionar de forma defensiva contra forças competitivas. Outra abordagem, o paradigma do conflito estratégico, teve início com o artigo intitulado “A Teoria da Estratégia de Negócios” (SHAPIRO, 1989). Esta segunda abordagem se baseia nas ferramentas da teoria dos jogos e consiste em analisar a natureza da interação competitiva entre empresas rivais. O que determina o potencial de lucro nessa abordagem é como uma empresa pode influenciar o comportamento e as ações de empresas rivais e, portanto, do ambiente de mercado (TEECE et. al, 1997). A terceira abordagem, representada pela "Visão Baseada em Recursos", enfatiza capacidades e ativos específicos, além da existência de mecanismos isolados como principais determinantes do desempenho organizacional (PENROSE, 1959; RUMELT, 1984; TEECE, 1984; WERNERFELT, 1984; TEECE et. al, 1997). Tal abordagem reconhece os recursos (e processos) específicos de uma empresa como fontes de lucro e vantagens competitivas a serem mantidas.

As três abordagens não devem ser vistas como mutuamente excludentes, mas como complementares e adequadas para diferentes contextos. Contudo, tais análises têm um desempenho inferior quando se trata de ajudar no entendimento de "como" e "por que" algumas organizações constroem vantagem competitiva em contextos de mudanças rápidas (TEECE et. al 1997).

Eisenhardt \& Martin (2000) concentram a análise de capacidades dinâmicas nos aspectos internos da organização, i.e., a existência de capacidades dinâmicas 
está relacionada com processos estratégicos e organizacionais. Teece (2007) associa as capacidades dinâmicas com a habilidade da organização em desenvolver novas estratégias mais rápido que os concorrentes, por meio do reconhecimento de diferentes recursos de valor. O dinamismo ambiental também foi associado a existência de capacidades dinâmicas (TEECE et al., 1997; WANG \& AHMED, 2007). Alguns autores focam no desenvolvimento das capacidades, i.e., na trajetória de acumulação de recursos e competências e nos mecanismos e dispositivos que configuram a existência de capacidades dinâmicas (ZOLLO \& WINTER, 2002). Ainda para outros autores, as capacidades dinâmicas são resultado de uma combinação de capacidades, ou seja, o construto capacidades dinâmicas seria definido a partir de uma hierarquia de capacidades mais simples e rotinas relacionadas (ANDREEVA \& CHAIKA, 2006; COLLIS, 1994; WANG \& AHMED, 2007; WINTER, 2003).

Várias dimensões organizacionais atuam para que uma empresa apresente competências diferenciadas e capacidades dinâmicas. Porém, Teece e colaboradores (1997) identificaram alguns fatores determinantes no desenvolvimento das capacidades dinâmicas, que podem ser consolidados em três classes - Processos, Posições e Trajetórias, detalhadas a seguir.

\section{Processos}

Os processos ou rotinas organizacionais e de gestão representam a maneira como as tarefas são normalmente realizadas pela empresa. Esses processos devem ter como objetivo não só a coordenação e integração das atividades (conceito estático), mas também o aprendizado organizacional (conceito dinâmico) e a reconfiguração da empresa (conceito transformacional). As rotinas de coordenação e integração devem ocorrer tanto em nível interno, com os funcionários da empresa, quanto em nível externo, com os parceiros comerciais e demais partes relacionadas. A empresa deve também ser capaz de identificar a necessidade de reconfiguração dos ativos corporativos e de realizar as transformações dela decorrente, tendo como base as melhores práticas, eventualmente levantadas através de benchmarking (TEECE et al., 1997). 


\section{Posição}

Os ativos que uma empresa possui influenciam o posicionamento estratégico que ela pode adotar (BARNEY, 1991). Esses ativos podem ser, segundo exemplificado por Teece et al. (1997), de natureza tecnológica, financeira, de reputação, estrutural (estrutura formal e informal da organização) ou institucional (sistemas regulatórios, leis de propriedade intelectual, leis antitruste, sistema educacional do país, etc.). Os autores ressaltam ainda que o posicionamento no mercado é uma ativo importante. Porém, em ambientes em que as mudanças tecnológicas ocorrem frequentemente, esse posicionamento e a participação de mercado (market share) dele decorrente é significativamente instável (TEECE et al., 1997).

\section{Trajetória}

O fator dependência de trajetória indica que, mesmo considerando que as opções de ação de uma empresa são decorrentes de sua posição atual e das alternativas disponíveis, a escolha da trajetória futura é fortemente influenciada pelas decisões e ações realizadas no passado. Em outras palavras, a conduta futura de uma empresa é limitada pelos investimentos já realizados e pela forma com que os seus processos e rotinas atuais evoluíram (TEECE et al., 1997).

Desta forma, Teece e coautores (1997) argumentam que as competências são decorrentes dos processos organizacionais e de gestão (Processos), porém o desenvolvimento dessas competências é significativamente influenciado pelos ativos que a empresa possui (Posição) e pelas decisões tomadas e caminhos percorridos pela organização no passado (Trajetória).

A partir do trabalho original de Teece et al. (1997), diversos estudos e pesquisas foram realizados por diferentes autores no sentido de desenvolver a base teórica do conceito capacidades dinâmicas. Entre 1997 e 2007, mais de 1.500 artigos, abrangendo todos os principais campos da Administração, utilizaram o conceito (BARRETO, 2010), com vários modelos conceituais e de pesquisa sendo propostos (e.g. WANG \& AHMED, 2007; MEIRELLES \& CAMARGO, 2014).

Em particular, numa evolução de seu trabalho original, Teece (2007) propôs que a sustentação das capacidades dinâmicas nas organizações seria dependente ainda da presença de algumas capacidades específicas - Percepção, 
Aproveitamento e Transformação - que foram por ele consideras fundamentais, conforme a Figura 6.

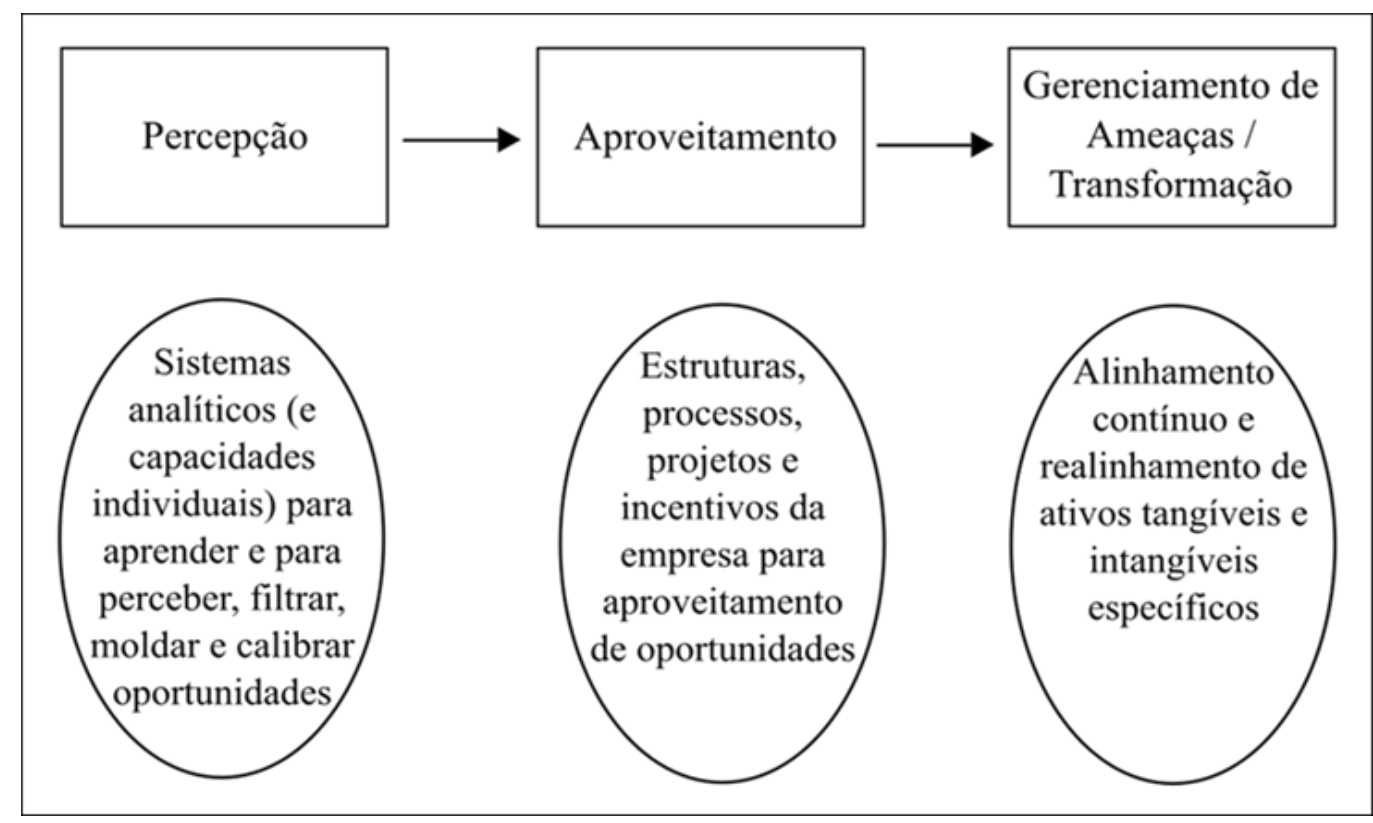

Figura 6 - Fundamentos das capacidades dinâmicas.

Fonte: Adaptado de Teece (2007).

Arend e Bromiley (2009) argumentam que há uma necessidade urgente de uma teoria e um modelo que sejam coerentes para as capacidades dinâmicas. Como os gerentes devem tomar decisões regularmente sobre como renovar as capacidades operacionais existentes em novas capacidades, que melhor correspondam ao ambiente em constante mutação, as capacidades dinâmicas representam um desafio importante na busca por uma vantagem competitiva sustentável (GREWAL \& SLOTEGRAAF, 2007). Em consequência, para entender melhor as capacidades dinâmicas, é importante reconhecer sua distinção das capacidades operacionais que elas buscam reconfigurar.

As capacidades são coleções de rotinas efetivamente executadas em relação à concorrência (WINTER, 2003). Embora as capacidades sejam conjuntos de rotinas, as capacidades dinâmicas envolvem reconfigurar e alterar rotinas, enquanto as capacidades operacionais denotam a capacidade de "ganhar a vida diária" (WINTER, 2003), i.e., capacidade de uma organização ao desempenhar "uma atividade em uma base contínua usando mais ou menos a mesma técnica na mesma escala para suportar produtos e serviços existentes para a mesma população de consumidores" (HELFAT \& WINTER, 2011, p. 1244). As 
capacidades operacionais foram denominadas por Winter (2003, p. 3) como capacidades comuns ou de "ordem zero", cujo objetivo é "ganhar a vida produzindo e vendendo o mesmo produto, na mesma escala e na mesma população de clientes". As capacidades operacionais podem ser definidas como a capacidade de executar atividades do dia-a-dia. Por outro lado, as capacidades dinâmicas são denominadas capacidades de "primeira ordem", cujo objetivo é mudar o produto, o processo de produção, a escala ou os mercados atendidos (Winter, 2003). Collis (1994) observou que as capacidades dinâmicas governam a mudança de capacidades operacionais, reconfigurando-as para mantê-las relevantes para o ambiente em mudança.

Estendendo o trabalho de Teece e colegas (TEECE et al. 1997; TEECE, 2007), Pavlou e Sawy (2011) propuseram um conjunto identificável e parcimonioso de capacidades dinâmicas. Os autores tiveram como ponto de partida as capacidades de Teece et al. (1997) (reconfigurar, aprender, integrar e coordenar) e Teece (2007) (sentir o ambiente para aproveitar oportunidades e reconfigurar ativos). De acordo com os autores, diferentes rótulos foram utilizados na literatura para se referir a capacidades semelhantes, ou rótulos semelhantes para diferentes capacidades. Pavlou e Sawy (2011) reconciliaram os vários rótulos e significados da literatura e os agruparam em um conjunto parcimonioso para refletir a conceituação de Teece et al. (1997) e Teece (2007), em sua própria interpretação da literatura, conforme a Figura 7.

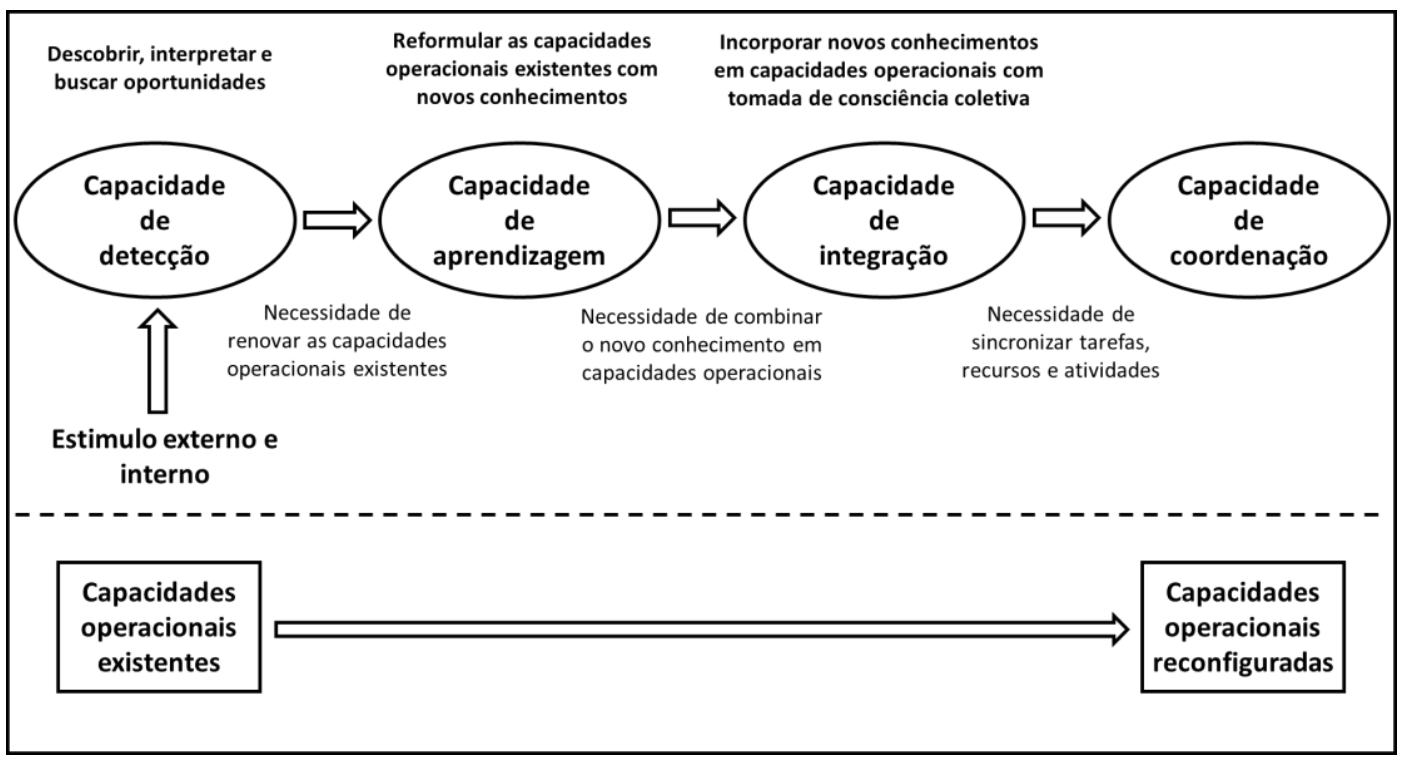

Figura 7 - Modelo de capacidades dinâmicas de Pavlou e Sawy (2011) Fonte: Adaptado de Pavlou e Sawy (2011). 
Reconfigurar os recursos operacionais e implantar novos recursos para lidar com ambientes turbulentos é o objetivo final das capacidades dinâmicas, que buscam alcançar a adequação evolutiva e evitar a rigidez (TEECE, 2007). A reconfiguração refere-se à adequação (GALUNIC \& RODAN, 1998), à exatidão (ZOTT, 2003) e à eficiência (KOGUT \& ZANDER, 1996), pelas quais as capacidades operacionais são reconfiguradas para se ajustarem ao ambiente. As capacidades dinâmicas propostas por Pavlou e Sawy (2011) como ferramentas para reconfigurar as capacidades operacionais existentes são: (i) capacidade de detecção; (ii) capacidade de aprendizagem, (iii) capacidade de integração e (iv) capacidade de coordenação. As capacidades dinâmicas propostas não são exaustivas, nem suficientes para que a reconfiguração ocorra, mas elas são postuladas como importantes facilitadores da capacidade de reconfigurar as capacidades operacionais (PAVLOU \& SAWY, 2011). A Tabela 4 contém a definição de cada uma das capacidades propostas por Pavlou e Sawy (2011).

Tabela 4 - Capacidades dinâmicas

\begin{tabular}{|l|l|}
\hline \multicolumn{1}{|c|}{ Capacidade } & \multicolumn{1}{c|}{ Definição } \\
\hline Capacidade de Detecção & $\begin{array}{l}\text { Capacidade de identificar, interpretar e buscar oportunidades } \\
\text { no ambiente }\end{array}$ \\
\hline Capacidade de Aprendizagem & $\begin{array}{l}\text { Capacidade de renovar as capacidades operacionais existentes } \\
\text { com novos conhecimentos. }\end{array}$ \\
\hline Capacidade de Integração & $\begin{array}{l}\text { Capacidade de incorporar novos conhecimentos às novas } \\
\text { capacidades operacionais, criando uma compreensão } \\
\text { compartilhada e tomada de consciência coletiva }\end{array}$ \\
\hline Capacidade de Coordenação & $\begin{array}{l}\text { Capacidade de orquestrar e implantar tarefas, recursos e } \\
\text { atividades nos novos recursos operacionais }\end{array}$ \\
\hline
\end{tabular}

Fonte: Adaptado de Pavlou e Sawy (2011).

Embora o conceito de capacidades dinâmicas tenha sido desenvolvido considerando a empresa como unidade de análise, a noção já foi empregada para analisar o desempenho operacional de subunidades organizacionais (Moreno, Carvalho \& Cavazotte, 2018). Com base na definição de Teece sobre os fundamentos do conceito (2007), neste estudo as capacidades dinâmicas de uma equipe são definidas como a capacidade do grupo de (1) perceber oportunidades e ameaças; (2) aproveitar oportunidades fazendo escolhas sobre alternativas de ação, investimentos e aplicação de recursos; e (3) reconfigurar/transformar estruturas organizacionais, seus recursos e/ou capacidades. 


\section{3.}

\section{Implicações da Liderança para a Geração de Capacidades Dinâmicas}

Um dos maiores desafios enfrentados pelos líderes atualmente é a necessidade de estruturar e capacitar organizações e pessoas para se adaptarem diante de ambientes turbulentos. Liderança para adaptabilidade organizacional envolve capacitar organizações e pessoas para lidar de forma efetiva com mudanças e incertezas. Seu foco está em como os líderes podem liberar o potencial dos sistemas e das pessoas para ajustá-las e adaptá-las de maneira satisfatória às necessidades de um ambiente em constante mutação (BURKE, PIERCE \& SALAS, 2006; HOOIJBERG, HUNT \& DODGE, 1997; ROSING, FRESE \& BAUSCH, 2011; UHL-BIEN \& MARION, 2009).

A liderança em adaptabilidade organizacional aborda como os líderes podem posicionar as organizações e as pessoas para lidar com desafios complexos. Ela aborda os requisitos para que as organizações e as pessoas dentro delas sejam flexíveis, ágeis e adaptáveis em resposta a mudanças associadas a um mundo volátil e muitas vezes imprevisível (DOZ \& KOSONEN, 2010; KEISTER, 2014; REEVES \& DEIMLER, 2011; UHL-BIEN , MARION \& MCKELVEY, 2007; WORLEY \& LAWLER, 2010).

A teoria das capacidades dinâmicas provoca o campo de estudos sobre liderança a discutir que tipo de atuação é capaz de promover a capacidade de uma organização se adaptar e evoluir ao longo do tempo (TEECE et al., 1997). A premissa central de teoria de capacidades dinâmicas é que os elementos tradicionais de sucesso nos negócios (e.g., capacidades operacionais) não são suficientes. Em vez disso, os líderes devem orquestrar cuidadosamente as capacidades operacionais e dinâmicas (TEECE et al., 1997). As capacidades operacionais trabalham para facilitar o uso eficiente e eficaz dos recursos, enquanto as capacidades dinâmicas permitem que uma organização se renove de acordo com o ambiente em mudança (TEECE, 2007). O papel dos líderes nessa perspectiva é identificar e moldar as oportunidades e ameaças; tirar proveito de oportunidades e manter a competitividade; e aprimorar, combinar, proteger e reconfigurar os ativos tangíveis e intangíveis da empresa (TEECE, 2007). 


\subsection{1. Lideranças transformacional, transacional e capacidades dinâmicas}

As organizações reconheceram a inovação como a porta de entrada crítica para obter vantagem competitiva e manter a prosperidade; nesse sentido, os gerentes são considerados líderes e defensores da inovação (ELKINS \& KELLER, 2003; MUMFORD, SCOTT, GADDIS, \& STRANGE, 2002). No atual ambiente - em constante mutação - as capacidades ordinárias (ou operacionais) representam apenas uma garantia de que as organizações estariam operando de acordo com as melhores práticas da indústria em que competem. Contudo, não são garantia de resultados superiores. As capacidades dinâmicas envolvem a capacidade de alterar, reconfigurar e inovar; e representam um desafio importante na busca por uma vantagem competitiva sustentável (GREWAL \& SLOTEGRAAF, 2007).

$\mathrm{Na}$ busca pela inovação, os líderes devem ser capazes de despertar a percepção de seus seguidores para a descoberta de novos negócios, novos processos, novos produtos (e serviços) e motivá-los a aproveitar as oportunidades geradas por essas descobertas. A liderança transformacional se apresenta como uma abordagem capaz de impulsionar esse comportamento necessário para a inovação organizacional e geração de capacidades dinâmicas, pois líderes transformacionais motivam os seus seguidores a alcançar resultados acima do esperado. De acordo com Bass (1990); Bass \& Avolio (1990), isso ocorre por meio da maior conscientização dos liderados com relação à importância e valor dos objetivos comuns estabelecidos e de levar os seguidores a privilegiarem os interesses da organização, acima dos seus próprios interesses. Na perspectiva de liderança transformacional, líderes e liderados se juntam e, a partir de valores comuns, procuram atingir os objetivos do grupo ou da organização, deixando de lado seus interesses pessoais (ANTONAKIS, 2012; BASS \& RIGGIO, 2006; BURNS, 1978). Desta forma, o maior interesse comum entre líder e liderados considerando-se o ambiente dinâmico no qual as organizações estão inseridas estaria no desenvolvimento de capacidades dinâmicas, i.e., na reconfiguração de capacidades operacionais de forma a mantê-las relevantes para o ambiente em constante mudança e, consequentemente, melhor desempenho organizacional. 
Teorias e pesquisas sobre liderança e inovação geralmente revelam dois processos essenciais através dos quais a liderança pode aumentar a criatividade e inovação, estimulando novas ideias e soluções por meio da manutenção e melhoria de um ambiente de trabalho autônomo e desenvolvimento de ideias e soluções por meio do fomento de metas e normas superordenadas (AMABILE, 1988; VAN DE VEN, 1986; WOODMAN, SAWYER, \& GRIFFIN, 1993). Líderes transformacionais, por estimular o interesse intelectual de seus membros e encorajá-los a buscar ideias e soluções amplamente para resolver tarefas desafiadoras, também podem promover a inovação através da motivação da aquisição de conhecimento externo à equipe (JIANG \& CHEN, 2018).

Comparado ao desempenho geral, o desempenho inovador está centrado na aplicação de novas ideias que provavelmente mudam as tecnologias e rotinas existentes; portanto, liderar a inovação pode envolver processos integrativos distintos, como atividades relacionadas ao conhecimento, para gerar e implementar novas ideias (JIANG \& CHEN, 2018). Além disso, a liderança transformacional estimula a curiosidade intelectual com questões que desafiam o status quo, o que também aumenta os processos de trabalho inovadores (JUNG, CHOW, \& WU, 2003; SHIN \& ZHOU, 2003).

Várias características da liderança transformacional são relevantes para a inovação da empresa (GUMUSLUOGLU \& İLSEV, 2009). Líderes transformacionais têm uma visão interativa; eles prestam a máxima atenção ao fomento de comunicação efetiva (ADAIR, 2007) e compartilhamento de valores e incentivo num ambiente apropriado para equipes inovadoras (TUSHMAN \& NADLER, 1986). Eles apoiam os processos coletivos de aprendizagem organizacional (MANZ et al., 1989), confiança recíproca entre membros e líderes da organização (SCOTT \& BRUCE, 1994) e atitudes favoráveis em relação à proatividade, risco (LEFEBVRE \& LEFEBVRE, 1992) e criatividade (TIERNEY et al., 1999). Todos esses recursos juntos permitem uma melhor compreensão das fortes relações entre a liderança transformacional e os fatores que influenciam positivamente a inovação e a adaptação organizacional (KANTER, 1983).

Finalmente, os líderes transformacionais têm carisma, fornecem inspiração e promovem estimulação intelectual. Essas características encorajam processos de comunicação e aprendizado organizacional que permitem que as organizações sejam mais inovadoras (BASS, 1999; CONGER, 1999). Em uma recente revisão 
da literatura, Hughes et al. (2018) observaram que a liderança transformacional é a abordagem mais frequentemente associada à criatividade e inovação (e.g., JUNG, WU \& CHOW, 2008; KAO, PAI, LIN, \& ZHONG, 2015), sendo sua influência explicada através do impacto do estímulo intelectual e da motivação inspiracional desses líderes em seus grupos.

Com base nessas evidências e argumentos propõe-se que:

H5: A liderança transformacional da equipe de projeto está positivamente associada à capacidade dinâmica da equipe.

Líderes transformacionais são capazes de apoiar, criar e estimular funcionários envolvidos em processos criativos. Por outro lado, os líderes transacionais estão focados na tarefa e na eficiência, coordenando os recursos existentes, que suportam os novos recursos. Apesar de existirem poucos estudos sobre a influência da liderança transacional para a geração de capacidades dinâmicas é importante investigar o seu papel de influência em um modelo que integre diferentes perspectivas de liderança, mais especificamente a liderança transformacional (e transacional), a liderança instrumental e a liderança empoderadora. Portanto, é necessário refinar as dimensões do comportamento da liderança transacional e das capacidades dinâmicas.

Com base nos argumentos expostos, propõe-se que:

H6: A liderança transacional da equipe de projeto está positivamente associada à capacidade dinâmica da equipe.

\subsection{2.}

\section{Liderança instrumental e capacidades dinâmicas}

A revisão de literatura do presente estudo apresentou - dentre outros - os conceitos de liderança instrumental e capacidades dinâmicas. O primeiro, como uma evolução do modelo "full range" de liderança, i.e., modelo de alcance total e o segundo, como uma abordagem estratégica para a geração de novas capacidades. Embora estudos sobre liderança instrumental e desempenho sejam ainda escassos, a pesquisa sobre essa associação tem sido evocada na literatura sobre criatividade e inovação (HUGHES et al., 2018), e é aqui proposta de forma inédita, com ênfase no conceito de capacidade dinâmica. 
De acordo com a literatura, é possível identificar mecanismos de integração entre os conceitos de liderança instrumental e de capacidades dinâmicas. Os conceitos de percepção, aproveitamento e transformação (sensing, seizing e reconfiguring) - sustentação das capacidades dinâmicas nas organizações permitem a integração com as dimensões da liderança instrumental, pois vão além do papel interpessoal do líder. A "percepção” envolve sentir novas oportunidades, é uma atividade de exploração, criação, aprendizado e interpretação (TEECE, 2007). Está alinhada tanto com a "liderança estratégica" - através da dimensão "monitoramento ambiental" - quanto com a "facilitação do trabalho do seguidor" - através da dimensão "monitoramento de resultados". Ambas exigem do líder a capacidade de examinar o ambiente interno e externo, mapear objetivos estratégicos e de tarefa; e fornecer feedback de desempenho. A liderança estratégica também possui a dimensão "formulação e execução da estratégia", que envolve o desenvolvimento de uma estratégia para o grupo de trabalho e investimento em tempo e recursos para implementar a estratégia (ANTONAKIS \& HOUSE, 2002); e estão em linha com as capacidades "aproveitamento" e "transformação".

A chave para o crescimento lucrativo sustentado é a capacidade de recombinar e reconfigurar ativos e estruturas organizacionais à medida que a empresa cresce, e os mercados e as tecnologias mudam. A reconfiguração é necessária para manter a capacidade evolutiva e, se necessário, tentar escapar de dependências desfavoráveis. A transformação envolve o alinhamento contínuo e realinhamento de ativos tangíveis e intangíveis específicos (TEECE, 2007). Para isto, o líder deve ajudar os seus seguidores nos problemas do dia-a-dia, removendo obstáculos, fornecendo recursos e guiando-os ao alcance de suas respectivas metas, i.e., os líderes ajudam os seus seguidores a entender o caminho em direção ao objetivo. A experiência de um líder é um pré-requisito importante para a facilitação do "caminho-meta".

A Tabela 5 resume a integração das dimensões da liderança instrumental com os fundamentos das capacidades dinâmicas. 
Tabela 5 - Liderança instrumental e capacidades dinâmicas.

\begin{tabular}{|c|c|c|}
\hline \multicolumn{2}{|c|}{ Categorias e Dimensões da Liderança Instrumental } & $\begin{array}{c}\text { Fundamentos das } \\
\text { Capacidades Dinâmicas }\end{array}$ \\
\hline \multirow{2}{*}{ Liderança estratégica } & Monitoramento ambiental & Percepção \\
\cline { 2 - 3 } & Formulação e implementação de estratégias & $\begin{array}{c}\text { Aproveitamento e } \\
\text { Transformação }\end{array}$ \\
\hline $\begin{array}{c}\text { Facilitação do } \\
\text { trabalho do seguidor }\end{array}$ & Facilitação do caminho meta & Transformação \\
\cline { 2 - 3 } & Monitoramento de resultados & Percepção \\
\hline
\end{tabular}

Fonte: Elaborado pelo autor.

Com base nos argumentos expostos, propõe-se a seguinte hipótese:

H7: A liderança instrumental da equipe de projeto está positivamente associada à capacidade dinâmica da equipe.

\subsection{3.}

\section{Liderança empoderadora e capacidades dinâmicas}

Para manter a competitividade ao longo do tempo, as organizações devem equilibrar a tensão entre a necessidade de inovar e a necessidade de produzir. Essas demandas concorrentes foram descritas por March (1991) como dois aspectos da aprendizagem organizacional: (1) exploração, ou seja, criação de novos conhecimentos, habilidades e processos para sustentar a viabilidade futura por meio de pesquisa, variedade, tomada de risco, experimentação, inovação e descoberta; e (2) explotação, ou seja, uso dos conhecimentos, habilidades e processos existentes para produzir resultados para o sucesso atual por meio de seleção, refinamento, escolha, eficiência e execução. Levinthal e March (1993) propõem que as organizações que gerenciam efetivamente essas demandas conflitantes são ambidestras - elas exploram as capacidades atuais (isto é, a explotação) e exploram competências fundamentalmente novas (ou seja, exploração).

A teoria das capacidades dinâmicas classifica as capacidades como, operacionais ou dinâmicas. As capacidades operacionais facilitam o uso eficiente e eficaz de recursos (e.g., explotação); e as capacidades dinâmicas permitem que uma organização renove suas competências para alcançar congruência com o ambiente em mutação (e.g., exploração) (DIXON, MEYER \& DAY, 2014). Embora a ambidestria possa surgir na estrutura formal ou nas declarações de visão 
de um líder carismático, ela tem mais chance de ser alcançada através da criação de contextos de apoio, nos quais os indivíduos escolhem como e onde focalizar suas energias (UHL-BIEN \& ARENA, 2018).

A liderança da ambidestria é uma característica exibida por todos os indivíduos da organização, e não apenas pelos que estão no topo; a ambidestria pode ser impulsionada por iniciativas de cima para baixo, mas o objetivo é permitir que a liderança emerja da organização em todos os níveis (BIRKINSHAW \& GIBSON, 2004). Essa liderança emergente envolve funcionários escolhendo como dividir o tempo entre atividades orientadas ao alinhamento (e.g., explorar o valor de ativos proprietários, implementar rapidamente modelos de negócios existentes e reduzir custos de operações existentes) e atividades orientadas para adaptação (e.g., ser ágil, inovador e proativo) (UHL-BIEN \& ARENA, 2018).

Funcionários ambidestros são motivados e informados para agir espontaneamente, sem buscar permissão ou apoio dos superiores, eles reconhecem a necessidade de buscar adaptabilidade enquanto permanecem claramente alinhados com a estratégia (BIRKINSHAW \& GIBSON, 2004). A liderança da ambidestria envolve, assim, incentivar pequenas adaptações contínuas que atualizam e ajustam a estratégia sem perder o alinhamento (BIRKINSHAW \& GIBSON, 2004). Para isso, os líderes devem promover e apoiar a tomada de iniciativas, cooperação, intermediação e a execução de múltiplas tarefas. Eles também devem ser e ter um estilo informal de gerenciamento, que incentive visões alternativas e novas abordagens (UHL-BIEN \& ARENA, 2018).

Neste cenário, a liderança empoderadora se apresenta como uma abordagem distinta das demais (e.g., diretiva, transacional e transformacional) e mostra como os líderes podem posicionar as suas organizações e as pessoas dentro delas para serem adaptáveis diante de desafios complexos. A liderança empoderadora envolve a transferência de poder da alta direção para trabalhadores com alta autonomia, permitindo que as organizações e as pessoas dentro delas sejam flexíveis, ágeis e adaptáveis em resposta a mudanças associadas a um mundo volátil e muitas vezes imprevisível.

Em sua revisão da literatura, Hughes e colaboradores (2018) identificaram um número pequeno de estudos sobre liderança empoderadora, criatividade e inovação, porém, com efeitos positivos de magnitude moderada e num intervalo 
bastante homogêneo (e.g., CHEN, SHARMA, EDINGER, SHAPIRO, \& FARH, 2011; SRIVASTAVA, BARTOL \& LOCKE, 2006), havendo fortes indícios de que o empoderamento psicológico é um mecanismo mediador importante nessa relação (ZHANG \& BARTOL, 2010; PAN, SUN \& CHOW, 2012).

Com base nos argumentos expostos, propõe-se a seguinte hipótese:

H8: A liderança empoderadora da equipe de projeto está positivamente associada à capacidade dinâmica da equipe.

\section{4.}

\section{Capacidades Dinâmicas e Desempenho}

Em ambientes de negócios em rápida evolução, a vantagem competitiva sustentável requer ativos e capacidades dinâmicas únicos e difíceis de replicar. As capacidades dinâmicas consistem de recursos necessários para que a empresa se adapte às novas oportunidades tecnológicas e de clientes, também incluem a capacidade da empresa de moldar o ecossistema que ocupa, desenvolver novos produtos e processos, assim como projetar e implementar modelos de negócios viáveis. Teece (2007) acredita que a excelência nessas capacidades de "orquestração" sustente a capacidade de uma empresa de inovar e captar com sucesso o valor suficiente para proporcionar um desempenho financeiro superior a longo prazo. Embora o desempenho de longo prazo da empresa seja determinado em alguma medida pela maneira como o ambiente de negócios recompensa sua herança, o desenvolvimento e o exercício de capacidades dinâmicas estão no cerne do sucesso empresarial (TEECE, 2007). Elas permitem que a empresa integre, construa e reconfigure recursos internos e externos para manter a liderança em ambientes de negócios em constante mudança (TEECE, 2014).

As capacidades dinâmicas possibilitam renovação organizacional, resolvem sistematicamente os problemas, permitindo que a organização tome decisões oportunas e orientadas para o mercado e introduza mudanças inovadoras na base de recursos (AMBROSINI \& BOWMAN, 2009; SCHILKE 2014; TEECE, 2014; WANG \& AHMED, 2007). O princípio fundamental da visão de capacidade dinâmica é que as capacidades dinâmicas estão associadas positivamente à vantagem competitiva e ao sucesso de desempenho de uma empresa (BARRETO, 2010). As capacidades dinâmicas aprimoram constantemente as capacidades 
ordinárias, o que tem maior probabilidade de resultar em eficiência superior (ZOLLO \& WINTER, 2002). Ao mesmo tempo, as capacidades dinâmicas envolvem a construção de novos recursos que podem conferir uma vantagem competitiva na medida em que ocorrem mudanças no ambiente competitivo (DANNEELS, 2015; TEECE, 2014).

Alguns autores argumentaram que as capacidades dinâmicas podem não necessariamente criar as configurações corretas de recursos (AMBROSINI \& BOWMAN, 2009; EISENHARDT \& e MARTIN, 2000) e implicar custos (LAVIE, 2006; PABLO et al., 2007). No entanto, outros apontaram que as capacidades dinâmicas tendem a ser valiosas (PETERAF et al., 2013), aprendidas à medida que as organizações respondem ao seu ambiente (WINTER, 2012) e que poderia haver um valor agregado apreciável e difícil de imitar para as empresas mais experientes (PETERAF et al., 2013). De acordo com ZOTT (2003), mudanças sistemáticas na base de recursos de uma organização podem resultar em diferenciais significativos de desempenho, porque essas atividades permitem que a organização acumule conhecimento sobre como mudar e com menos custos, aumentando assim a congruência com o meio ambiente.

Diversos estudos (e.g., FAINSHMIDT et al., 2016; PEZESHKAN, FAINSHMIDT, NAIR, FRAZIER \& MARKOWSKI, 2016) destacam a associação positiva entre capacidades dinâmicas e resultados de desempenho. FAINSHMIDT et al. (2016) argumentam que a relação entre capacidades dinâmicas e desempenho é mais sutil. Especificamente, destaca-se que essa associação depende de fatores contextuais. Além disso, a teoria (e.g., GIROD \& WHITTINGTON, 2017) debate se as capacidades dinâmicas são mais propícias a vantagens competitivas e níveis mais altos de desempenho em ambientes operacionais estáveis ou dinâmicos. FANG \& ZOU (2009) descobriram que as capacidades dinâmicas de marketing de joint ventures internacionais levam a um desempenho superior, porque permitem que esses empreendimentos acompanhem mudanças no ambiente do consumidor e respondam a ele. Da mesma forma, Heimeriks et al. (2012) demonstram o impacto positivo das práticas de gerenciamento de risco e transferência tácita de conhecimento, como capacidades dinâmicas, no desempenho financeiro pós-aquisição. Além disso, Stadler et al. (2013) fornecem evidências de um impacto positivo dos atributos de capacidade 
dinâmica no desenvolvimento bem-sucedido de recursos valiosos e difíceis de imitar na indústria de petróleo.

Com base nas evidências apresentadas, espera-se que as capacidades dinâmicas, em geral, estejam positivamente relacionadas ao desempenho organizacional, conforme as hipóteses a seguir:

H9a: As capacidades dinâmicas de equipes de projeto estão positivamente associadas ao seu desempenho financeiro (lucro).

H9b: As capacidades dinâmicas de equipes de projetos estão positivamente associadas ao seu desempenho na ótica do cliente (satisfação dos clientes).

H9c: As capacidades dinâmicas de equipes de projetos estão positivamente associadas à sua capacidade de criar novos projetos junto ao cliente (DNA empreendedor).

As três hipóteses anteriores apresentaram a possibilidade das capacidades dinâmicas estarem positivamente associadas ao desempenho das equipes de projeto, contudo, existe a possibilidade de que esse feito também ocorra a partir das competências globais de liderança. Conforme apresentado nas proposições do presente estudo, a integração das quatro diferentes perspectivas sobre liderança abordadas (perspectivas transformacional, transacional, instrumental e empoderadora) acionam mecanismos de motivação intrínsecos e extrínsecos, que por sua vez, irão formar as competências globais de liderança. Desta forma, as competências globais de liderança do gerente de projeto representam os diferentes comportamentos de liderança capazes de gerar um desempenho positivo, conforme as seguintes hipóteses:

H1Oa: As competências globais de liderança do gerente de projeto estão positivamente associadas ao desempenho financeiro do projeto (lucro).

H10b: As competências globais de liderança estão positivamente associadas ao desempenho do projeto na ótica do cliente (satisfação dos clientes).

H10c: As competências globais de liderança estão positivamente associadas à capacidade da equipe de criar novos projetos junto ao cliente (DNA empreendedor). 


\section{3. \\ Metodologia}

Este capítulo apresenta a metodologia de pesquisa utilizada nesta tese. A primeira seção descreve o contexto em que a pesquisa foi conduzida e descreve amostra utilizada neste estudo. A seguir, a segunda seção detalha informações sobre os instrumentos de medida aplicados para coletar os dados. A terceira e última seção deste capítulo descreve como foi conduzida a coleta de dados em si.

\section{1.}

\section{Seleção dos Informantes}

O universo da pesquisa foi a empresa de consultoria Elogroup. Fundada em 2007 na Incubadora de Empresas do Parque Tecnológico da Universidade Federal do Rio Janeiro (UFRJ), a empresa abriu seu primeiro escritório no Rio de Janeiro, tendo sido a empresa com o menor tempo a se graduar na Incubadora da COPPEUFRJ. Em 2012, foi eleita a sexta melhor empresa para se trabalhar com sede no Rio de Janeiro, na primeira vez em que concorreu a listagem das melhores do Great Place to Work. Em 2013, foi eleita em primeiro lugar na categoria Empresa Graduada no Prêmio Nacional de Empreendedorismo Inovador, promovido pela Anprotec e a segunda melhor empresa para se trabalhar com sede no Rio de Janeiro, na lista do Great Place to Work. Atualmente, a Elogroup possui cerca de 300 funcionários, com escritórios no Rio de Janeiro, São Paulo, Brasília, Minas Gerais, Fortaleza e Vitória, e já atua em 12 países.

A unidade de análise da pesquisa foram as equipes de projetos da Elogroup. A pesquisa foi realizada com base em dois questionários on-line, cujos links foram enviados por e-mail, para serem respondidos pelos líderes das equipes de projetos e seus respectivos subordinados. 


\section{2. \\ Instrumentos de Coleta de Dados}

A unidade de análise da pesquisa foram as equipes de projetos da empresa de consultoria Elogroup. Para a execução da pesquisa foram desenvolvidos dois questionários, um para cada grupo de respondentes: líderes das equipes de projetos (Apêndice A) e componentes (subordinados) das equipes de projetos (Apêndice B).

Nos questionários foram utilizadas questões fechadas, com escalas, previamente validadas e internacionalmente aceitas (Quadro 13), nas quais os respondentes fizeram escolhas diante das alternativas apresentadas.

O questionário respondido pelos líderes (Questionário 1) possui 25 itens. Os 19 primeiros itens são referentes às capacidades dinâmicas desenvolvidos por Pavlou e Sawy (2011). A Tabela 6 apresenta um resumo com as subescalas adotadas para medir o construto capacidades dinâmicas nesse instrumento.

Tabela 6 - Escalas adotadas para medir o construto capacidades dinâmicas

\begin{tabular}{|c|c|c|c|c|}
\hline \multicolumn{5}{|c|}{ Construto: Capacidades Dinâmicas } \\
\hline Dimensões & $\begin{array}{c}\mathrm{N}^{\text {o }} \text { de } \\
\text { Itens }\end{array}$ & Fonte & Questões & Tipo de Medida \\
\hline $\begin{array}{c}\text { Capacidade de } \\
\text { Detecção }\end{array}$ & 4 & & $1-4$ & Escala Likert de 5 pontos \\
\hline $\begin{array}{c}\text { Capacidade de } \\
\text { Aprendizagem }\end{array}$ & 5 & \multirow{2}{*}{ Pavlou \& Sawy (2011) } & $5-9$ & Escala Likert de 5 pontos \\
\cline { 1 - 2 } $\begin{array}{c}\text { Capacidade de } \\
\text { Integração }\end{array}$ & 5 & & $10-14$ & Escala Likert de 5 pontos \\
\cline { 5 - 5 } $\begin{array}{c}\text { Capacidade de } \\
\text { Coordenação }\end{array}$ & 5 & & $15-19$ & Escala Likert de 5 pontos \\
\end{tabular}

Fonte: Elaborado pelo autor.

No início do questionário havia uma lista com os nomes de 158 projetos já realizados pela empresa, para que o líder pudesse indicar qual deles liderou e iria responder. Os projetos fazem parte do portfólio de projetos da Elogrup e seus nomes foram fornecidos pela empresa. Os demais itens no questionário dos líderes referem-se a variáreis de controle: três indicadores demográficos (sexo, idade e escolaridade) e três indicadores relacionados a experiência de trabalho do respondente (tempo de experiência profissional, tempo na empresa, e tempo na equipe). 
As métricas sobre o desempenho das equipes foram fornecidas pela empresa. A primeira delas é o lucro bruto de cada projeto, avaliado em reais. A segunda métrica de desempenho fornecida pela empresa diz respeito à satisfação dos clientes com relação aos projetos. Tais notas consideram a recorrência de vendas de projetos para o mesmo cliente (indica a satisfação do cliente), o crescimento do volume de negócios dentro do mesmo cliente (indica o nível de confiança) e o aumento do nível de interlocução (indica a importância que a Elogroup conquistou em um cliente). A terceira medida fornecida pela empresa avalia o intraempreendedoríssimo das equipes de projeto, i.e. a capacidade da equipe de criar novas demandas junto a clientes ao longo de projetos em andamento, que viabilizem a prototipagem ou desenvolvimento de novos produtos da Elogroup. Este indicador de desempenho das equipes de projeto é considerado essencial para a empresa, sendo internamente denominado "DNA empreendedor".

O questionário respondido pelos liderados (Questionário 2) possui 44 itens. Os 20 primeiros itens são indicadores referentes a liderança transformacional, e foram extraídos do Multifactor Leadership Questionnare (MLQ), propostos por Bass e Avolio (1995). Os oito itens seguintes foram desenvolvidos por Antonakis e House (2014) e se referem a liderança instrumental. Os 12 itens seguintes se referem a liderança empoderadora e foram desenvolvidos por Arnold et al. (2000). Os quatro últimos itens se referem a liderança transacional e também foram extraídos do MLQ. A Tabela 7 apresenta um resumo com as escalas adotadas para medir os construtos liderança transformacional, transacional, liderança instrumental e liderança empoderadora. 
Tabela 7 - Escalas adotadas para medir os construtos liderança transformacional, liderança instrumental e liderança empoderadora

\begin{tabular}{|c|c|c|c|c|c|}
\hline \multicolumn{6}{|c|}{ Construto: Liderança } \\
\hline Escalas & Dimensões & $\begin{array}{l}\mathrm{N}^{\mathrm{o}} \mathrm{de} \\
\text { Itens }\end{array}$ & Fonte & Questões & Tipo de Medida \\
\hline \multirow{5}{*}{$\begin{array}{c}\text { Liderança } \\
\text { Transformacional }\end{array}$} & $\begin{array}{c}\text { Influência Idealizada } \\
\text { (atributo) }\end{array}$ & 4 & \multirow{5}{*}{$\begin{array}{l}\text { Avolio \& Bass } \\
\text { (1995) }\end{array}$} & $4,9,11$ e 13 & $\begin{array}{c}\text { Escala Likert de } \\
5 \text { pontos }\end{array}$ \\
\hline & $\begin{array}{c}\text { Influência Idealizada } \\
\text { (comportamento) }\end{array}$ & 4 & & $1,7,12$ e 19 & $\begin{array}{c}\text { Escala Likert de } \\
5 \text { pontos } \\
\end{array}$ \\
\hline & $\begin{array}{c}\text { Motivação } \\
\text { Inspiracional } \\
\end{array}$ & 4 & & $3,6,14$ e 20 & $\begin{array}{c}\text { Escala Likert de } \\
5 \text { pontos } \\
\end{array}$ \\
\hline & $\begin{array}{c}\text { Estimulação } \\
\text { Intelectual }\end{array}$ & 4 & & $2,5,16$ e 18 & $\begin{array}{c}\text { Escala Likert de } \\
5 \text { pontos } \\
\end{array}$ \\
\hline & $\begin{array}{c}\text { Consideração } \\
\text { Individualizada }\end{array}$ & 4 & & $\begin{array}{c}8,10,15 \mathrm{e} \\
17 \\
\end{array}$ & $\begin{array}{c}\text { Escala Likert de } \\
5 \text { pontos } \\
\end{array}$ \\
\hline \multirow{4}{*}{$\begin{array}{l}\text { Liderança } \\
\text { Instrumental }\end{array}$} & $\begin{array}{c}\text { Monitoramento } \\
\text { Ambiental }\end{array}$ & 2 & \multirow{4}{*}{$\begin{array}{l}\text { Antonakis \& } \\
\text { House (2014) }\end{array}$} & 21 e 22 & $\begin{array}{c}\text { Escala Likert de } \\
5 \text { pontos }\end{array}$ \\
\hline & $\begin{array}{c}\text { Planejamento e } \\
\text { Implementação da } \\
\text { Estratégia } \\
\end{array}$ & 2 & & 23 e 24 & $\begin{array}{l}\text { Escala Likert de } \\
5 \text { pontos }\end{array}$ \\
\hline & $\begin{array}{c}\text { Facilitação do } \\
\text { caminho-objetivo }\end{array}$ & 2 & & 25 e 26 & $\begin{array}{c}\text { Escala Likert de } \\
5 \text { pontos } \\
\end{array}$ \\
\hline & $\begin{array}{c}\text { Monitoramento dos } \\
\text { Resultados }\end{array}$ & 2 & & 27 e 28 & $\begin{array}{c}\text { Escala Likert de } \\
5 \text { pontos } \\
\end{array}$ \\
\hline \multirow{4}{*}{$\begin{array}{c}\text { Liderança } \\
\text { Empoderadora }\end{array}$} & $\begin{array}{c}\text { Aumento do } \\
\text { significado do } \\
\text { trabalho }\end{array}$ & 3 & \multirow{4}{*}{$\begin{array}{l}\text { Ahearne et al. } \\
\qquad(2005)\end{array}$} & 29,30 e 31 & $\begin{array}{c}\text { Escala Likert de } \\
7 \text { pontos }\end{array}$ \\
\hline & $\begin{array}{c}\text { Participação na } \\
\text { tomada de decisão }\end{array}$ & 3 & & 32,33 e 34 & $\begin{array}{c}\text { Escala Likert de } \\
7 \text { pontos } \\
\end{array}$ \\
\hline & Confiança & 3 & & 35,36 e 37 & $\begin{array}{c}\text { Escala Likert de } \\
7 \text { pontos } \\
\end{array}$ \\
\hline & Automia & 3 & & 38,39 e 40 & \begin{tabular}{|c} 
Escala Likert de \\
7 pontos \\
\end{tabular} \\
\hline $\begin{array}{c}\text { Liderança } \\
\text { Transacional }\end{array}$ & $\begin{array}{l}\text { Recompensa } \\
\text { condicional }\end{array}$ & 4 & $\begin{array}{c}\text { Avolio \& Bass } \\
(1995)\end{array}$ & $\begin{array}{c}41,42,43 \mathrm{e} \\
44\end{array}$ & $\begin{array}{c}\text { Escala Likert de } \\
5 \text { pontos }\end{array}$ \\
\hline
\end{tabular}

Fonte: Elaborado pelo autor.

A exemplo do questionário respondido pelo líder, no início do questionário havia uma lista com 158 projetos para que os liderados pudessem indicar em qual participou e iria responder. Os projetos fazem parte do portfólio de projetos da Elogrup e foram indicados pela empresa. Os demais itens referem-se a variáreis de controle: três indicadores demográficos (sexo, idade e escolaridade) e três indicadores relacionados a experiência de trabalho do liderado (tempo de experiência profissional, tempo na empresa, e tempo na equipe). 


\section{3.}

\section{Coleta dos Dados}

Para a coleta dos dados, os links para os dois questionários (Questionário 1 e Questionário 2) foram enviados às respectivas fontes (líder ou liderado) por email. O Questionário 1 foi enviado para os responsáveis pelas equipes de consultoria (líderes das equipes de projetos) da empresa Elogroup. Foram obtidas respostas de líderes para 81 dos 158 projetos listados. Dos 81 questionários respondidos, 61 foram respondidos por completo. Os demais questionários (20) foram descartados, pois estavam incompletos. O Questionário 2 foi enviado para os integrantes das equipes de projetos (liderados) funcionários da empresa Elogroup. Dos 250 questionários enviados, 132 foram respondidos. Dos 132 questionários respondidos, 69 foram respondidos por completo. Os demais questionários (63) foram descartados, pois estavam incompletos. A amostra com as equipes de projeto foi formada unindo-se os dados das respostas dos líderes aos dos liderados através do nome do projeto de que fizeram parte. A amostra final foi composta por 50 equipes de projeto. Os dados de desempenho das equipes foram fornecidos por um dos sócios fundadores da Elogroup, com os indicadores de desempenho dos projetos (lucro bruto, satisfação dos clientes e DNA empreendedor). 


\section{4 \\ Análise dos Resultados}

\section{1.}

\section{Características Demográficas da Amostra}

Neste estudo, líderes e liderados responderam voluntariamente aos questionários, sem qualquer interação entre ambos na coleta de dados. As 50 equipes de projeto que formam a amostra deste estudo tiveram líderes com idade média de 30 anos, sendo 42 anos a idade do líder mais velho e 27 anos do líder mais novo. A média de idade dos liderados nestas equipes é de 26 anos, tendo o liderado mais velho 36 anos e o liderado mais novo 20 anos. Quanto ao sexo dos líderes das equipes de projeto, na amostra 32 líderes (64\%) são do sexo masculino e 18 líderes (32\%) do sexo feminino. Quanto ao sexo dos liderados, na amostra 38 liderados são do sexo masculino (60\%) e 25 liderados (40\%) do sexo feminino. Com relação a escolaridade dos líderes das equipes de projeto, 22 líderes (44\%) possuem ensino superior completo e 28 líderes (56\%) possuem pós-graduação. Com relação a escolaridade dos liderados, 13 liderados (21\%) possuem ensino superior incompleto, 38 liderados (60\%) possuem ensino superior completo e 12 liderados possuem pós-graduação (19\%).

Os líderes das equipes de projeto possuem em média nove anos de experiência, sendo 20 anos o líder mais experiente e quatro anos o líder menos experiente. Os liderados possuem em média quatro anos de experiência, sendo 15 anos o liderado mais experiente e seis meses o liderado menos experiente. Quanto ao tempo como gestor dos líderes das equipes de projeto, a média é de quatro anos, sendo que o maior tempo de um líder como gestor na amostra em estudo é de 12 anos e o menor tempo de um líder como gestor um ano. Quanto ao tempo de trabalho de um liderado com o líder do projeto, a média é de um ano, o maior tempo de trabalho junto ao líder do projeto é de dois anos e o menor tempo junto ao líder do projeto é de quatro meses. Com relação ao tempo do líder na empresa, a média é de cinco anos, sendo que o maior tempo de um líder na empresa de 12 anos e o menor tempo de um líder na empresa cinco anos. 
Os subordinados das equipes de projetos (liderados) não foram escolhidos pelos líderes e responderam aos questionários voluntariamente. Como na amostra apenas um subordinado respondeu por cada equipe, não foi necessário calcular o rwg, medida de concordância entre os membros dentro do grupo (JAMES, DEMAREE \& WOLF, 1993).

\section{2. Análise do Modelo de Mensuração}

Todos os construtos incluídos no modelo proposto foram medidos com escalas desenvolvidas e testadas em estudos anteriores e passaram por avaliação de especialistas, o que garante a validade de conteúdo e a validade de face.

A técnica dos mínimos quadrados parciais (PLS) foi utilizada para testar o modelo de mensuração na amostra deste estudo. A PLS é conhecida por sua capacidade de lidar com construtos reflexivos e formativos, além da capacidade de testar efeitos de moderação, e apresenta robustez em relação a desvios de normalidade multivariada, multicolinearidade dentro e entre blocos de variáveis latentes manifestas, má especificação do modelo estrutural (omissão de regressores) e amostras pequenas (e.g., CASSEL, HACKL, \& WESTLUND, 1999; CHIN, 1998; CHIN \& NEWSTED, 1999; PATNAYAKUNI et al., 2006; URBACH \& AHLEMANN, 2010; VINZI, TRINCHERA, \& AMATO, 2010).

A estimação do modelo e o teste estatístico foram realizados com o software SmartPLS versão 2.0 (RINGLE, WENDE \& WILL, 2005). A técnica de bootstrapping $(\operatorname{casos}=50$; amostras $=500)$ foi empregada para calcular a significância dos efeitos estimados. Nesta seção são apresentados os resultados do modelo de mensuração para os construtos reflexivos e formativos.

\section{Construtos Reflexivos}

O modelo de mensuração foi avaliado de acordo com a abordagem descrita por Wetzels, Odekerken-Schroder \& Van Oppen (2009). Para esse propósito, um modelo nulo que interconecta todas as variáveis latentes de primeira ordem foi especificado no SmartPLS, tanto para os construtos levantados pelo Questionário 1 (questionário respondido pelos líderes), quanto para aqueles levantados pelo Questionário 2 (questionário respondido pelos liderados). O software foi 
configurado de forma que a direção das setas que ligavam as variáveis não foi levada em consideração (TENENHAUS \& HANAFI, 2010, p. 101).

Em relação ao Questionário 1 (questionário respondido pelos líderes), a matriz de cargas cruzadas obtida a partir da análise fatorial confirmatória (CFA) indicou que a maioria dos 36 itens relacionados aos construtos de primeira ordem apresentou cargas estatisticamente significativas acima de 0,7 ( $p<0,001$ ), indicando que pelo menos $50 \%$ da variação desses itens poderia ser explicada pelas respectivas variáveis latentes. Um total de 11 itens apresentaram cargas abaixo de 0,7. Nove itens foram eliminados (CD_2, CD_4, CD_5, CD_6, CD_10, CD_11, CD_12, CD_16 e CD_17), todos da escala de capacidades dinâmicas. Posteriormente, foi realizada uma segunda CFA. Os resultados mostraram que todos os itens carregaram adequadamente em suas respectivas variáveis. As cargas permaneceram estatisticamente significantes no nível 0,001.

A Tabela 8 sintetiza os resultados gerais do modelo de mensuração, incluindo a confiabilidade composta, a variância média extraída (AVE), o alfa de cronbach e as cargas para todas as variáveis latentes de primeira ordem. Exceto por "Detecção" (para o alfa de cronbach), todas as medidas estão acima dos valores mínimos sugeridos na literatura $(\mathrm{CR}>0,7$; $\mathrm{AVE}>0,5 ; \alpha \mathrm{C}>0,7)(\mathrm{CHIN}$, 1998; FORNELL \& LARCKER, 1981; HAIR et al., 2009; PATNAYAKUNI et al., 2006; VINZI, TRINCHERA E AMATO, 2010). É importante destacar que Chin (1998) argumenta que a confiabilidade composta é considerada um melhor indicador da confiabilidade de uma escala que o alfa de Cronbach. Portanto, as escalas utilizadas para avaliar os construtos de primeira ordem do modelo proposto mostraram consistência interna adequada e validade convergente (FORNELL \& LARCKER, 1981; HAIR et al., 2009).

Tabela 8 - Modelo de mensuração reflexivo (Questionário 1): resultados gerais

\begin{tabular}{c|c|c|c}
\hline Dimensão/Construto & $\mathbf{A V E}$ & Confiabilidade Composta & Alfa de Cronbach \\
\hline Detecção & 0,66 & 0,80 & 0,50 \\
\hline Aprendizagem & 0,68 & 0,86 & 0,76 \\
\hline Integração & 0,78 & 0,88 & 0,73 \\
\hline Coordenação & 0,59 & 0,81 & 0,70 \\
\hline
\end{tabular}


Os valores diagonais na Tabela 9 representam a raiz quadrada do AVE para cada variável latente. De acordo com Fornell \& Larcker (1981; ver também CHIN, 1998; HAIR et al., 2009), a validade discriminante pode ser avaliada verificando se a raiz quadrada do AVE para uma dada variável latente é maior do que todas as suas correlações com as demais variáveis latentes. Os resultados mostrados na Tabela 9 confirmam que o modelo de mensuração possui validade discriminante aceitável.

Tabela 9 - Modelo de mensuração reflexivo (Questionário 1): resultados

\begin{tabular}{|c|c|c|c|c|}
\hline Dimensão/Construto & 1 & 2 & 3 & 4 \\
\hline 1. Detecção & $\mathbf{0 , 8 2}$ & & & \\
\hline 2. Aprendizagem & 0,62 & $\mathbf{0 , 8 2}$ & & \\
\hline 3. Integração & 0,44 & 0,48 & 0,89 & \\
\hline 4. Coordenação & 0,39 & 0,53 & 0,77 & 0,77 \\
\hline
\end{tabular}

Quanto ao Questionário 2 (questionário respondido pelos liderados), a matriz de cargas cruzadas obtida a partir da CFA indicou que a maioria dos 44 itens relacionados aos construtos de primeira ordem apresentou cargas estatisticamente significativas acima de 0,7 ( $\mathrm{p}<0,001)$, indicando que pelo menos $50 \%$ da variação desses itens poderia ser explicada pelas respectivas variáveis latentes. Três itens apresentaram cargas abaixo de 0,7, todos da escala de liderança transformacional. Apenas um item foi eliminado (LTRANSF_18). Posteriormente, foi realizado uma segunda CFA. Os resultados mostraram que todos os itens carregaram adequadamente em suas respectivas variáveis. As cargas permaneceram estatisticamente significantes no nível 0,001.

A Tabela 10 sintetiza os resultados gerais do modelo de mensuração, incluindo a confiabilidade composta, a variância média extraída (AVE), o alfa de cronbach e as cargas para todas as variáveis latentes de primeira ordem. Todas as medidas estão acima dos valores mínimos sugeridos na literatura (CR>0,7; AVE> 0,5; $\alpha \mathrm{C}>0,7)(\mathrm{CHIN}, 1998$; FORNELL \& LARCKER, 1981; HAIR et al., 2009; PATNAYAKUNI et al., 2006; VINZI, TRINCHERA E AMATO, 2010). Portanto, as escalas utilizadas para avaliar os construtos de primeira ordem do modelo proposto mostraram consistência interna adequada e validade convergente (FORNELL \& LARCKER, 1981; HAIR et al., 2009). 
Tabela 10 - Modelo de mensuração reflexivo (Questionário 2): resultados gerais

\begin{tabular}{l|c|c|c|c}
\hline \multicolumn{1}{c|}{ Construto } & Dimensão & AVE & $\begin{array}{c}\text { Confiabilidade } \\
\text { Composta }\end{array}$ & $\begin{array}{c}\text { Alfa de } \\
\text { Cronbachs }\end{array}$ \\
\hline Lid. Transformacional & Carisma_at & 0,70 & 0,90 & 0,85 \\
\hline Lid. Transformacional & Carisma_co & 0,57 & 0,84 & 0,74 \\
\hline Lid. Transformacional & Consideração & 0,66 & 0,88 & 0,83 \\
\hline Lid. Transformacional & Estímulo & 0,75 & 0,90 & 0,83 \\
\hline Lid. Transformacional & Inspiração & 0,65 & 0,88 & 0,82 \\
\hline Lid. Instrumental & Clareza_meta & 0,80 & 0,89 & 0,75 \\
\hline Lid. Instrumental & Facilitação & 0,86 & 0,93 & 0,84 \\
\hline Lid. Instrumental & Monitoramento_a & 0,86 & 0,92 & 0,84 \\
\hline Lid. Instrumental & Monitoramento_r & 0,93 & 0,97 & 0,93 \\
\hline Lid. Empoderadora & Autonomia & 0,73 & 0,89 & 0,82 \\
\hline Lid. Empoderadora & Confiança & 0,80 & 0,92 & 0,89 \\
\hline Lid. Empoderadora & Participação & 0,82 & 0,93 & 0,89 \\
\hline Lid. Empoderadora & Significado & 0,90 & 0,97 & 0,95 \\
\hline Lid. Transacional & Transacional & 0,65 & 0,88 & 0,82 \\
\hline
\end{tabular}

Os valores diagonais na Tabela 11 representam a raiz quadrada do AVE para cada variável latente. Os valores apresentados são maiores do que todas as suas correlações com as demais variáveis latentes, indicando que o modelo de mensuração possui validade discriminante aceitável. 
Tabela 11 - Modelo de mensuração reflexivo (Questionário 2): resultados

\begin{tabular}{|c|c|c|c|c|c|c|c|c|c|c|c|c|c|c|}
\hline Dimensão & 1 & 2 & 3 & 4 & 5 & 6 & 7 & 8 & 9 & 10 & 11 & 12 & 13 & 14 \\
\hline 1. Carisma_at & $\mathbf{0 , 8 3}$ & & & & & & & & & & & & & \\
\hline 2. Carisma_co & 0,66 & 0,75 & & & & & & & & & & & & \\
\hline 3. Consideração & 0,79 & 0,70 & $\mathbf{0 , 8 1}$ & & & & & & & & & & & \\
\hline 4. Estímulo & 0,78 & 0,54 & 0,78 & $\mathbf{0 , 8 6}$ & & & & & & & & & & \\
\hline 5. Inspiração & 0,69 & 0,70 & 0,59 & 0,59 & $\mathbf{0 , 8 0}$ & & & & & & & & & \\
\hline 6. Clareza_meta & 0,48 & 0,54 & 0,65 & 0,49 & 0,50 & $\mathbf{0 , 8 9}$ & & & & & & & & \\
\hline 7. Facilitação & 0,65 & 0,63 & 0,71 & 0,54 & 0,52 & 0,72 & $\mathbf{0 , 9 3}$ & & & & & & & \\
\hline 8. Monitoramento_a & 0,52 & 0,39 & 0,52 & 0,61 & 0,30 & 0,46 & 0,50 & 0,93 & & & & & & \\
\hline 9. Monitoramento_r & 0,66 & 0,65 & 0,77 & 0,59 & 0,49 & 0,63 & 0,70 & 0,48 & 0,97 & & & & & \\
\hline 10. Autonomia & 0,73 & 0,54 & 0,69 & 0,67 & 0,54 & 0,41 & 0,41 & 0,37 & 0,54 & $\mathbf{0 , 5 8}$ & & & & \\
\hline 11. Confiança & 0,45 & 0,40 & 0,65 & 0,36 & 0,33 & 0,29 & 0,35 & 0,21 & 0,41 & 0,51 & 0,90 & & & \\
\hline 12. Participação & 0,52 & 0,39 & 0,60 & 0,62 & 0,38 & 0,52 & 0,46 & 0,43 & 0,47 & 0,57 & 0,41 & 0,91 & & \\
\hline 13. Significado & 0,48 & 0,69 & 0,69 & 0,51 & 0,55 & 0,71 & 0,67 & 0,36 & 0,69 & 0,45 & 0,38 & 0,55 & 0,95 & \\
\hline 14. Transacional & 0,65 & 0,67 & 0,71 & 0,55 & 0,64 & 0,67 & 0,71 & 0,50 & 0,76 & 0,45 & 0,47 & 0,56 & 0,76 & $\mathbf{0 , 8 1}$ \\
\hline
\end{tabular}




\section{Construtos Formativos}

A análise dos resultados da modelagem corrobora os construtos formativos propostos. Os comportamentos de liderança transformacional $(\beta=0,72 ; \mathrm{t}=$ $23,97 ; \mathrm{p}<0,001)$ e de liderança empoderadora $(\beta=0,34 ; \mathrm{t}=11,41 ; \mathrm{p}<0,001)$ estão significativamente associados ao construto latente de segunda ordem ações que mobilizam mecanismos de motivação intrínsecos, conforme a Tabela 12. Do mesmo modo, os resultados dão suporte à proposição de que comportamentos de liderança instrumental $(\beta=0,54 ; \mathrm{t}=13,51 ; \mathrm{p}<0,001)$ e de liderança transacional $(\beta=0,51 ; \mathrm{t}=13,22 ; \mathrm{p}<0,001)$ estão associados ao construto latente de segunda ordem ações que mobilizam mecanismos de motivação intrínsecos extrínsecos, conforme a Tabela 12. Os resultados também corroboram o construto latente de terceira ordem proposto, competências globais de liderança, formado pelas ações de liderança que mobilizam mecanismos de motivação intrínsecos ( $\beta$ $=0,55 ; \mathrm{t}=12,98 ; \mathrm{p}<0,001)$ e de mecanismos de motivação extrínsecos $(\beta=0,50 ;$ $\mathrm{t}=12,00 ; \mathrm{p}<0,001$ ), sendo a carga dos mecanismos de motivação intrínsecos um pouco maior do que a dos mecanismos de motivação extrínsecos, conforme a Tabela 12.

Tabela 12 - Modelo de mensuração formativo: efeitos diretos

\begin{tabular}{l|c|c|c}
\multicolumn{1}{c|}{ Efeitos Diretos } & $\begin{array}{c}\text { Original } \\
\text { Sample }\end{array}$ & Sample Mean & T Statistics \\
\hline $\begin{array}{l}\text { Lid. Transformacional -> Mec. de Motivação } \\
\text { Intrinsecos }\end{array}$ & 0,72 & $0,71^{* *}$ & 23,97 \\
\hline $\begin{array}{l}\text { Lid. Empoderadora -> Mec. de Motivação } \\
\text { Intrinsecos }\end{array}$ & 0,34 & $0,34^{* *}$ & 11,41 \\
\hline $\begin{array}{l}\text { Lid. Instrumental -> Mec. de Motivação } \\
\text { Extrinsecos }\end{array}$ & 0,54 & $0,55^{* *}$ & 13,51 \\
\hline $\begin{array}{l}\text { Lid. Transacional -> Mec. de Motivação } \\
\text { Extrinsecos }\end{array}$ & 0,51 & $0,51^{* *}$ & 13,22 \\
\hline $\begin{array}{l}\text { Mec. de Motivação Intrinsecos -> Comp. } \\
\text { Globais de Liderança }\end{array}$ & 0,55 & $0,56^{* * *}$ & 12,98 \\
\hline $\begin{array}{l}\text { Mec. de Motivação Extrinsecos -> Comp. } \\
\text { Globais de Liderança }\end{array}$ & 0,50 & $0,50^{* * *}$ & 12,00 \\
\hline
\end{tabular}

Assim, a análise confirma o modelo hierárquico proposto no contexto de equipes consultivas de projeto, indicando que competências globais de liderança observadas pelos membros das equipes no gerente do projeto são formadas pela combinação de comportamentos associados às quatro perspectivas estudadas, transformacional, transacional, instrumental e empoderadora, por duas vias 
distintas, o acionamento de mecanismos de motivação intrínsecos e de mecanismos de motivação extrínsecos.

\section{3. \\ Análise do Modelo Estrutural}

Os resultados relacionados aos efeitos diretos e indiretos do modelo são apresentados a seguir. Quanto aos efeitos da liderança transformacional nos critérios de desempenho no modelo proposto, os resultados não foram estatisticamente significantes para a hipótese H1a $(\beta=0,01 ; \mathrm{t}=0,32 ; \mathrm{p}<0,001)$, porém, foram estatisticamente significantes para as hipóteses $\mathrm{H} 1 \mathrm{~b} \quad(\beta=0,22 ; \mathrm{t}=$ $4,88 ; \mathrm{p}<0,001)$ e H1c $(\beta=0,25 ; \mathrm{t}=6,24 ; \mathrm{p}<0,001)$, permitindo rejeitar a hipótese nula para as duas últimas, e indicando que a liderança transformacional está positivamente associada aos critérios de desempenho de satisfação dos clientes e DNA empreendedor no modelo testado, conforme a Tabela 13.

Com relação as hipóteses H2a, H2b e H2c, quanto aos efeitos da liderança transacional nos critérios de desempenho, os resultados não apresentaram valores estatisticamente significantes para a hipótese $\mathrm{H} 2 \mathrm{a}(\beta=0,01 ; \mathrm{t}=0,32 ; \mathrm{p}<0,001)$, porém, foram estatisticamente significantes para as hipóteses $\mathrm{H} 2 \mathrm{~b}(\beta=0,14 ; \mathrm{t}=$ 4,56; $\mathrm{p}<0,001)$ e $\mathrm{H} 2 \mathrm{c}(\beta=0,16 ; \mathrm{t}=6,25 ; \mathrm{p}<0,001)$, permitindo rejeitar a hipótese nula para as duas últimas, e indicando que a liderança transacional está positivamente associada aos critérios de desempenho de satisfação dos clientes e DNA empreendedor, conforme a Tabela 13.

Os resultados para o teste das hipóteses $\mathrm{H} 3 \mathrm{a}, \mathrm{H} 3 \mathrm{~b}$ e $\mathrm{H} 3 \mathrm{c}$, quanto aos efeitos da liderança instrumental nos critérios de desempenho, não apresentaram valores estatisticamente significantes para a hipótese $\mathrm{H} 3 \mathrm{a}(\beta=0,01 ; \mathrm{t}=0,32 ; \mathrm{p}<0,001)$, porém, foram estatisticamente significantes para as hipóteses $\mathrm{H} 3 \mathrm{~b} \quad(\beta=0,15 ; \mathrm{t}=$ 4,59; $\mathrm{p}<0,001)$ e $\mathrm{H} 3 \mathrm{c}(\beta=0,17 ; \mathrm{t}=6,10 ; \mathrm{p}<0,001)$ permitindo rejeitar a hipótese nula para as duas últimas, e indicando que a liderança instrumental está positivamente associada aos critérios de desempenho de satisfação dos clientes e DNA empreendedor, conforme a Tabela 13.

Os valores apresentados para o teste das hipóteses $\mathrm{H} 4 \mathrm{a}, \mathrm{H} 4 \mathrm{~b}$ e $\mathrm{H} 4 \mathrm{c}$, quanto aos efeitos da liderança empoderadora nos critérios de desempenho, não apresentaram valores estatisticamente significantes para a hipótese $\mathrm{H} 4 \mathrm{a}$ ( $\beta=$ 
$0,001 ; \mathrm{t}=0,31 ; \mathrm{p}<0,001)$, porém, foram estatisticamente significantes para as hipóteses e H4b $(\beta=0,10 ; \mathrm{t}=5,38 ; \mathrm{p}<0,001)$ e $\mathrm{H} 4 \mathrm{c}(\beta=0,12 ; \mathrm{t}=5,38 ; \mathrm{p}<$ $0,001)$ permitindo rejeitar a hipótese nula para as duas últimas, e indicando que a liderança empoderadora está positivamente aos critérios de desempenho de satisfação dos clientes e DNA empreendedor, conforme a Tabela 13.

Quanto aos resultados relacionados as hipóteses $\mathrm{H} 5, \mathrm{H} 6, \mathrm{H} 7$ e $\mathrm{H} 8$, os valores não foram estatisticamente significantes, não sendo possível rejeitar as hipóteses nulas (Tabela 13). Ou seja, os resultados não permitem confirmar que os comportamentos de liderança propostos por esta tese (liderança transformacional, liderança transacional, liderança instrumental e liderança empoderadora) estão positivamente associado à capacidade dinâmica da equipe na avaliação do gerente do projeto.

Conforme os resultados do modelo estrutural para os efeitos diretos do modelo, também apresentados na Tabela 13, o teste das hipóteses H9a, H9b e H9c, não apresentaram valores estatisticamente significantes para as hipóteses H9a $(\beta=0,14 ; \mathrm{t}=1,35 ; \mathrm{p}<0,001)$ e H9c $(\beta=0,29 ; \mathrm{t}=1,46 ; \mathrm{p}<0,001)$, porém, foram estatisticamente significantes para a hipótese $\mathrm{H9b}(\beta=0,16 ; \mathrm{t}=2,05 ; \mathrm{p}<$ $0,001)$, permitindo rejeitar a hipótese nula e indicando que as capacidades dinâmicas de equipes de projetos estão positivamente associadas ao seu desempenho na ótica do cliente (satisfação dos clientes). Os resultados para o teste das hipóteses H10a, H10b e H10c, não apresentaram valores estatisticamente significantes para a hipótese H10a $(\beta=0,02 ; \mathrm{t}=0,21 ; \mathrm{p}<0,001)$, porém, foram estatisticamente significantes para as hipóteses $\mathrm{H} 10 \mathrm{~b}(\beta=0,53 ; \mathrm{t}=5,55 ; \mathrm{p}<$ $0,001)$ e H10c $(\beta=0,62 ; \mathrm{t}=6,61 ; \mathrm{p}<0,001)$, permitindo rejeitar a hipótese nula e indicando que as competências globais de liderança estão positivamente associadas aos critérios de desempenho de satisfação dos clientes e DNA empreendedor nas equipes de projeto estudadas, sendo o efeito no DNA empreendedor de maior magnitude do que na satisfação de clientes, conforme a Tabela 13.

Tabela 13 - Modelo estrutural: efeitos totais

\begin{tabular}{|l|c|c|c|}
\hline \multicolumn{1}{|c|}{ Efeitos Totais (Diretos e Indiretos) } & $\begin{array}{c}\text { Original } \\
\text { Sample }\end{array}$ & $\begin{array}{c}\text { Sample } \\
\text { Mean }\end{array}$ & T Statistics \\
\hline Lid. Transformacional -> Lucro & 0,01 & 0,01 & 0,32 \\
\hline Lid. Transformacional -> Satisfação Clientes & 0,22 & $0,22 * *$ & 4,88 \\
\hline
\end{tabular}




\begin{tabular}{|c|c|c|c|}
\hline Efeitos Totais (Diretos e Indiretos) & $\begin{array}{c}\text { Original } \\
\text { Sample }\end{array}$ & $\begin{array}{l}\text { Sample } \\
\text { Mean }\end{array}$ & T Statistics \\
\hline Lid. Transformacional -> DNA & 0,25 & $0,25 * *$ & 6,24 \\
\hline Lid. Transacional -> Lucro & 0,01 & 0,01 & 0,32 \\
\hline Lid. Transacional -> Satisfação Clientes & 0,15 & $0,14 * *$ & 4,56 \\
\hline Lid. Transacional -> DNA & 0,16 & $0,16^{* *}$ & 6,25 \\
\hline Lid. Instrumental -> Lucro & 0,01 & 0,01 & 0,32 \\
\hline Lid. Instrumental -> Satisfação Clientes & 0,15 & $0,15 * *$ & 4,59 \\
\hline Lid. Instrumental -> DNA & 0,17 & $0,17 * *$ & 6,10 \\
\hline Lid. Empoderadora -> Lucro & 0,01 & 0,01 & 0,31 \\
\hline Lid. Empoderadora -> Satisfação Clientes & 0,10 & $0,11^{* *}$ & 5,38 \\
\hline Lid. Empoderadora -> DNA & 0,12 & $0,12 * *$ & 5,38 \\
\hline Lid. Transformacional -> Cap Dinâmica & 0,03 & 0,04 & 0,43 \\
\hline Lid. Transacional -> Cap Dinâmica & 0,02 & 0,03 & 0,41 \\
\hline Lid. Instrumental -> Cap Dinâmica & 0,02 & 0,03 & 0,42 \\
\hline Lid. Empoderadora -> Cap Dinâmica & 0,02 & 0,02 & 0,43 \\
\hline Cap Dinâmica -> Lucro & 0,14 & 0,16 & 1,35 \\
\hline Cap Dinâmica -> Satisfação Clientes & 0,29 & $0,28 * *$ & 2,05 \\
\hline Cap Dinâmica -> DNA & 0,16 & 0,16 & 1,46 \\
\hline Comp. Globais de Liderança -> Lucro & 0,03 & 0,04 & 0,32 \\
\hline Comp. Globais de Liderança -> Satisfação Clientes & 0,56 & $0,56 * *$ & 5,13 \\
\hline Comp. Globais de Liderança -> DNA & 0,63 & $0,63 * *$ & 6,77 \\
\hline Lid. Transformacional -> Comp. Globais de Liderança & 0,40 & $0,40 * *$ & 14,69 \\
\hline Lid. Empoderadora -> Comp. Globais de Liderança & 0,19 & $0,19 * *$ & 7,83 \\
\hline Lid. Instrumental -> Comp. Globais de Liderança & 0,27 & $0,27 * *$ & 12,31 \\
\hline Lid. Transacional -> Comp. Globais de Liderança & 0,26 & $0,26 * *$ & 8,03 \\
\hline Mec. de Motivação Intrínsecos -> Lucro & 0,02 & 0,02 & 0,32 \\
\hline Mec. de Motivação Intrínsecos -> Satisfação Clientes & 0,31 & $0,31 * *$ & 5,11 \\
\hline Mec. de Motivação Intrínsecos -> DNA & 0,35 & $0,35 * *$ & 6,02 \\
\hline Mec. de Motivação Intrínsecos -> Cap Dinâmica & 0,05 & 0,05 & 0,43 \\
\hline Mec. de Motivação Extrínsecos -> Lucro & 0,02 & 0,02 & 0,32 \\
\hline Mec. de Motivação Extrínsecos -> DNA & 0,32 & $0,32 * *$ & 6,55 \\
\hline Mec. de Motivação Extrínsecos -> Satisfação Clientes & 0,28 & $0,28 * *$ & 4,64 \\
\hline Mec. de Motivação Extrínsecos -> Cap Dinâmica & 0,04 & 0,05 & 0,41 \\
\hline Comp. Globais de Liderança -> Cap Dinâmica & 0,08 & 0,10 & 0,42 \\
\hline
\end{tabular}


A Figura 8 apresenta o modelo estrutural proposto por esta tese com os valores para os efeitos em cada variável e o coeficiente de determinação $\left(R^{2}\right)$. É possível observar que o modelo explica apenas $2 \%$ da variância da variável dependente lucro, enquanto que para as variáveis satisfação dos clientes e DNA empreendedor o modelo apresentou um bom ajuste, explicando $40 \%$ e $43 \%$ da variância para estas variáveis dependentes respectivamente. As variáveis de controle utilizadas (sexo do líder da equipe, tempo de experiência profissional do líder da equipe, tempo do líder da equipe como gestor e tempo do líder da equipe na empresa) não apresentaram efeitos significativos sobre as variáveis dependentes (lucro do projeto satisfação dos clientes e DNA empreendedor), conforme a Figura 8. 


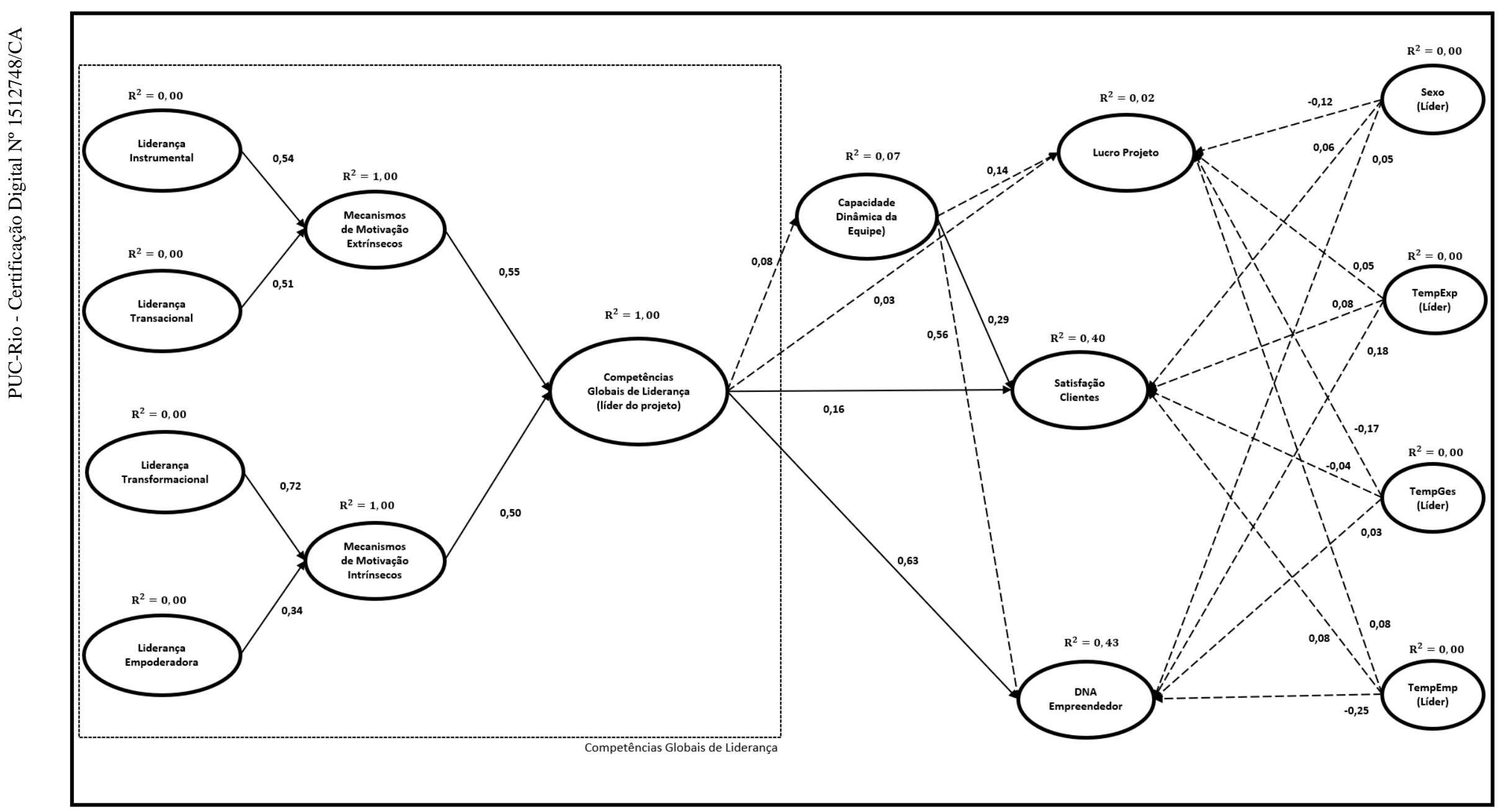

Figura 8 - Modelo estrutural 


\section{4 . \\ Estudo Exploratório Sobre o Construto Capacidades Dinâmicas}

Por ter relevância para esta tese, a título de estudo, foi analisado separadamente um modelo para avaliar os efeitos de cada uma das sub-dimensões das capacidades dinâmicos nas três variáveis dependentes relacionadas ao desempenho (lucro, esatisfação de clientes e DNA empreendedor). Os resultados do teste mostraram que, na amostra em estudo, o único efeito que apresentou significância entre as sub-dimensões das capacidades dinâmicas e as variáveis de desempenho foi o da sub-dimensão aprendizagem no critério de satisfação de clientes $(\beta=0,46 ; \mathrm{t}=2,71 ; \mathrm{p}<0,001)$. Nenhum outro efeito do modelo estudado apresentou significância estatística.

Em se tratando de capacidades dinâmicas, a aprendizagem é a capacidade de transformar as capacidades operacionais existentes com novos conhecimentos. Os itens utilizados para medir a capacidade de aprendizagem aparentam representar a capacidade da equipe de projetos de desenvolver novos conhecimentos de forma a permitir a renovação das capacidades ordinárias, conforme a Tabela 14 .

Tabela 14 - Itens utilizados para medir a capacidade de aprendizagem

\section{Indicadores}

A equipe tem rotinas eficazes para identificar, valorizar e absorver novas informações e conhecimentos.

A equipe tem rotinas adequadas para assimilar novas informações e conhecimentos.

A equipe é eficaz em transformar as informações existentes em novos conhecimentos.

A equipe é eficaz na utilização de conhecimento em novos serviços.

A equipe é eficaz no desenvolvimento de novos conhecimentos que podem influenciar o desenvolvimento de novas soluções e serviços.

A métrica de satisfação dos clientes com relação aos projetos considera os critérios de recorrência de vendas de projetos para o mesmo cliente (indica a satisfação do cliente), o crescimento do volume de negócios dentro do mesmo cliente (indica o nível de confiança) e o aumento do nível de interlocução (indica a importância que a Elogroup conquistou em um cliente). Como a atividade de consultoria, em geral, envolve um alto nível de interação entre a equipe de consultoria e o cliente, é possível que em equipes de projeto de consultoria a identificação e desenvolvimento de novos conhecimentos tenha um impacto mais 
imediato na percepção dos clientes do que nos outros critérios de desempenho analisados (lucro e DNA empreendedor).

Porém, por esta tese conter um estudo inédito envolvendo as capacidades dinâmicas no nível de equipes, e não no nível organizacional, existe a possibilidade de que a operacionalização do construto utilizada não seja a mais adequada para capturar o contexto específico de equipes de consultoria em projetos.

A Figura 9 abaixo apresenta o modelo estudado com os testes de significância para os efeitos das sub-dimensões das capacidades dinâmicas nas variáveis de desempenho. 


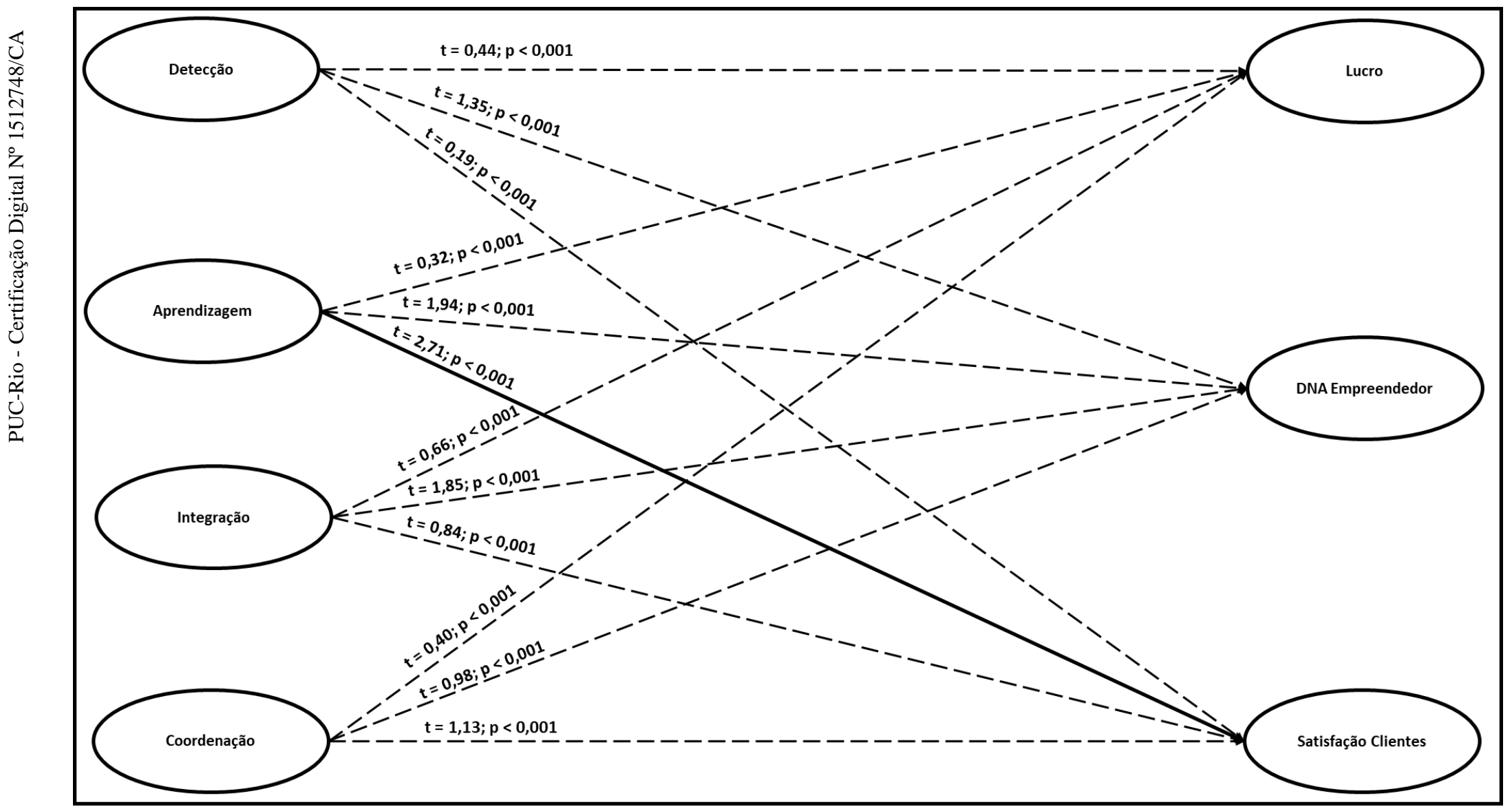

Figura 9 - Testes de significância (modelo capacidades dinâmicas) 


\section{5. \\ Conclusão}

\section{1. Discussão e Síntese do Estudo}

O objetivo desta tese foi analisar as conexões conceituais entre diferentes perspectivas de liderança na geração de capacidades dinâmicas e obtenção de vantagem competitiva. Foi desenvolvido e testado um modelo conceitual que articula princípios das perspectivas transformacional, transacional (BASS, 1985), instrumental (ANTONAKIS \& HOUSE, 2014) e empoderadora (PEARCE \& SIMS, 2002) da liderança e sua importância relativa para a geração de capacidades dinâmicas e consequentemente, para o desempenho de equipes de projeto.

Com o propósito de responder às questões de pesquisa propostas, foi desenvolvido um modelo teórico, a partir de uma revisão de literatura profunda dos campos de liderança e estratégia. Com base em teorias de motivação e sua articulação teórica com as perspectivas de liderança estudadas, foi proposto um modelo hierárquico onde comportamentos de liderança ressaltados nas perspectivas de liderança transformacional, transacional, instrumental e empoderadora constituem ações de um líder que mobilizam mecanismos de motivação intrínsecos e extrínsecos (construtos de segunda ordem) para formar competências globais de liderança (construto de terceira ordem), e por via dessas competências influenciarem o desempenho de equipes de trabalho (equipes de consultoria em projetos). $\mathrm{O}$ estudo também propõe uma associação entre as competências de liderança do gerente de projeto e as capacidades dinâmicas das equipes, tendo a última um papel mediador na relação entre liderança e o desempenho das equipes.

O modelo conceitual foi testado estatisticamente através dos mínimos quadrados parciais (PLS) com a utilização do software SmartPLS versão 2.0 (RINGLE, WENDE \& WILL, 2005). O modelo de mensuração foi avaliado e 
técnicas de bootstrapping ( $\operatorname{casos}=50$; amostras $=500$ ) foram empregadas para calcular a significância dos efeitos estimados.

A partir da análise das respostas de uma amostra de 50 equipes de consultoria em projetos e teste do modelo, verificou-se os efeitos positivos das competências de liderança abordadas por este estudo no desempenho de equipes de consultoria, avaliado em termos da satisfação de clientes e do DNA empreendedor (medida de empreendedorismo interno nas equipes de projeto, i.e. a capacidade da equipe de criar novos projetos junto ao cliente), mas não no lucro bruto dos projetos. Esses achados estão em linha com diversos autores (e.g. ANTONAKIS \& DAY, 2017; BASS, 1985; BASS, 1999; DINH et al., 2014: JUDGE \& PICCOLO, 2004) que sugerem a importância dos diferentes comportamentos de liderança para o desempenho organizacional.

Porém, os resultados da análise não mostraram qualquer efeito positivo dos comportamentos de liderança transformacional, transacional, instrumental e empoderadora nas capacidades dinâmicas das equipes. Por se tratar de um contexto de equipes de projetos, é possível que o tempo de planejamento e execução de um projeto não seja suficiente para que o líder (do projeto) possa influenciar o desenvolvimento de todo o ciclo que envolve a geração de capacidades dinâmicas (detecção, aprendizagem, integração e coordenação). Além disso, existe a possibilidade de que o nível de análise utilizado para observar capacidades dinâmicas não seja adequado, ou que os fenômenos relacionados ao construto capacidades dinâmicas no nível do grupo ou unidade organizacional não se manifestem de forma exatamente análoga ao que ocorre no nível da organização.

A análise dos efeitos indiretos corrobora as proposições desenvolvidas nesta tese, de que ações de liderança associadas a mecanismos intrínsecos de motivação são formadas pelos comportamentos transformacional e empoderador do líder, e que ações de liderança associadas a mecanismos extrínsecos de motivação são formadas pelos comportamentos instrumental e transacional do líder. Da mesma forma, também corroboram a proposição de que competências globais de liderança são formadas simultaneamente por comportamentos do líder associados a esses dois mecanismos de motivação (intrínsecos e extrínsecos). Tais proposições permitem a integração das quatro perspectivas de liderança através dos aportes teóricos do campo da motivação, e sugerem que os líderes combinam 
diferentes comportamentos, associados às perspectivas de liderança abordadas nesta tese, que em seu conjunto formam competências globais de um líder.

Kanfer et al. (2017) argumentam que a motivação extrínseca tem um efeito reforçador a motivação intrínseca. Para Hennessey et al. (2015), a motivação intrínseca e a motivação extrínseca podem combinar sinergicamente para gerar altos níveis de desempenho e satisfação pessoal. Esta tese compartilha esse entendimento. Em seu papel de influenciador, o líder pode equilibrar tanto o uso de mecanismos de influência extrínsecos (recompensas, definição de metas, direção), quanto de influência intrínsecos (autonomia, propósito/visão, significado, valores) para motivar seus seguidores em busca de um objetivo.

As capacidades dinâmicas não apresentaram o efeito mediador entre as competências globais de liderança e o desempenho para as medidas lucro bruto e DNA empreendedor, porém, confirmou-se a hipótese de que o efeito das competências globais de liderança nos resultados em termos da satisfação dos clientes é mediado pela capacidade dinâmica da equipe de projeto. É possível que a operacionalização do construto capacidades dinâmicas utilizada neste estudo não seja adequada considerando-se a equipe de trabalho como unidade de análise. Apesar das equipes de trabalho representarem uma porção da empresa e de como ela atua (através de suas rotinas e processos), o construto capacidades dinâmicas considerado para essas equipes precisa ser lapidado para refletir as nuances associadas as atividades específicas do dia a dia de uma equipe de projeto.

De acordo com os resultados, as competências globais de liderança têm efeitos positivos no desempenho quando avaliado por critérios menos tangíveis (DNA empreendedor e satisfação de clientes) do que mais tangíveis (lucro bruto). Contudo, é válido ressaltar que a medida de satisfação dos clientes para a Elogroup tem uma avaliação um pouco mais objetiva que o DNA empreendedor, pois considera a recorrência de vendas de projetos para o mesmo cliente, o crescimento do volume de negócios dentro do mesmo cliente e o aumento do nível de interlocução. Já o lucro possui aspectos que não estão diretamente no controle da equipe, pois está relacionado com o valor de venda do projeto. A duração do projeto e sua complexidade também podem afetar o lucro pela necessidade de maior dispêndio de recursos, gerando custos mais altos e, consequentemente, reduzindo o lucro. 
Esses resultados também vão de encontro a sugestão de Antonakis \& Day (2017) para a busca de uma integração das diferentes perspectivas sobre liderança existentes no campo, e sugerem que a combinação entre os diferentes comportamentos de liderança abordados nesta tese (perspectivas transformacional, transacional, instrumental e empoderadora) geram sinergias e são benéficos para o desempenho de equipes de projetos. Do ponto de vista prático, esses resultados são relevantes e apontam para a importância da escolha e treinamento de líderes capacitando a implementação de ações capazes de mobilizar mecanismos de motivação intrínsecos, como inspirar e dar autonomia a seus seguidores, bem como de mecanismos de motivação extrínsecos, como manter distribuir incentivos e monitorar metas e resultados.

\section{2.}

\section{Contribuições do Estudo}

Este estudo está em consonância com a demanda por estudos que busquem uma integração das diferentes perspectivas sobre liderança existentes no campo (e.g., ANTONAKIS \& DAY, 2017, DIHN et al. 2014). Esta tese buscou a integração das perspectivas transformacional, transacional, instrumental e empoderadora de liderança de uma forma inédita. Do ponto de vista acadêmico, a união dessas perspectivas pode estabelecer as bases para que se possa testar teorias mais gerais de liderança. O conhecimento desenvolvido neste estudo permitirá a utilização de atributos essenciais à liderança efetiva, capazes de promover vantagens competitivas em empresas, assim produzindo bases para o desenvolvimento gerencial e capacitação de lideranças, particularmente de equipes de projeto. Do ponto de vista empresarial, mostrou-se que na busca por desempenho, as organizações podem treinar, desenvolver e incentivar líderes capazes de desempenhar os diferentes tipos de comportamento associados as perspectivas de liderança transformacional, transacional, instrumental e empoderadora.

Dessa forma, a pesquisa contribui com informações úteis para programas de desenvolvimento e formação de lideranças nas empresas brasileiras, visando a geração de vantagens competitivas, capazes de alavancar inovação em negócios no Brasil. 
Em recente chamada de artigos para o The Leadership Quarterly, Bonardi, Hitt, Vera \& Withers (2018) ressaltam a falta de diálogo entre os pesquisadores em liderança nos campos de organizações, psicologia e estratégia. Como consequência dessa não integração, os termos utilizados não são uniformes, os construtos são desconexos, as perguntas de pesquisa eventualmente acabam duplicadas, conclusões de pesquisas não são adequadamente consideradas em estudos posteriores, ocorre fragmentação dos resultados e superposição de diferentes teorias. O presente estudo também buscou o diálogo do campo da liderança (através das diferentes perspectivas abordadas) com o da estratégia (através das capacidades dinâmicas). Apesar de não ter sido comprovado os efeitos positivos da liderança nas capacidades dinâmicas e nem seu efeito mediador para o desempenho é possível que estudos posteriores possam buscar novas operacionalizações com bases nos conceitos aqui abordados.

\section{3. \\ Limitações do Método}

Dentre as limitações do estudo, destaca-se, em primeiro lugar, o tamanho da amostra. Apesar de a técnica dos mínimos quadrados parciais ser capaz de lidar com amostras pequenas (e.g., CASSEL, HACKL, \& WESTLUND, 1999; CHIN, 1998; CHIN \& NEWSTED, 1999; PATNAYAKUNI et al., 2006; URBACH \& AHLEMANN, 2010; VINZI, TRINCHERA, \& AMATO, 2010) as 50 equipes de trabalho da amostra (equipes de consultoria em projetos) possuíam apenas um integrante (além do líder) e por isso, não foi possível calcular o rwg, medida de concordância entre os membros dentro do grupo (JAMES, DEMAREE \& WOLF, 1993). Sem a possibilidade de se verificar a concordância entre os membros do grupo, a opinião a respeito do líder pode limitar-se a visão de apenas um membro e não refletir a opinião do grupo como um todo.

Mesmo o questionário não contendo a identificação dos respondentes, uma potencial limitação do método deste estudo está relacionada aos vieses de respostas socialmente aceitáveis por parte dos respondentes. A participação voluntária também pode produzir um viés de auto seleção, relacionado a um interesse particular na participação. 
Outra limitação do presente estudo é que tanto líderes, quanto liderados, possam ter participado de outros diversos projetos ao longo de suas trajetórias na Elogroup e venham a confundir suas respostas relacionadas aos projetos os quais selecionaram para responder em seus questionários.

A operacionalização do construto capacidades dinâmicas também se caracteriza como limitação deste estudo. É possível que a operacionalização utilizada, apesar de amplamente testada por outros estudos, não seja adequada para o contexto de equipes de trabalho. Novas pesquisas podem buscar alternativas para a operacionalização do construto capacidades dinâmicas ou mesmo desenvolver novas medidas que sejam mais adequadas para o contexto de equipes de trabalho.

\section{4 .}

\section{Agenda de Pesquisas Futuras}

Futuras pesquisas sobre o tema liderança, capacidades dinâmicas e desempenho, poderão investigar outros fatores existentes nas relações desses construtos, propondo novas questões, assim como para corrigir ou confirmar a inexistência das relações envolvendo liderança e capacidades dinâmicas no contexto de equipes de trabalho.

A partir deste estudo, novas investigações sobre o tema poderão ser úteis na ampliação do conhecimento sobre a influência das competências globais de liderança no desempenho organizacional. Além disso, pode-se acrescentar ao modelo, comportamentos de liderança característicos de outras perspectivas existentes no campo (e.g., liderança compartilhada e liderança empreendedora).

Novas investigações sobre o tema poderão incluir antecedentes aos diferentes estilos de liderança para investigar, por exemplo, a influência de traços de personalidade (neuroticismo, extroversão, abertura a novas experiências, simpatia e conscienciosidade) nos diferentes comportamentos de liderança estudados.

Outra possibilidade para estudos futuros é a inclusão de outras variáveis (diferentes das capacidades dinâmicas) que possam apresentar um efeito mediador entre as competências globais de liderança e o desempenho. 
Por fim, um estudo longitudinal que acompanhasse as equipes de trabalho ao longo do tempo, em diversos projetos, poderia conseguir capturar quanto tempo uma equipe deve ficar junta para que seja possível o desenvolvimento de todo o ciclo necessário para a geração de capacidades dinâmicas (detecção, aprendizagem, integração e coordenação) e consequentemente, a obtenção de vantagens competitivas. 


\section{6 \\ Referências Bibliográficas}

ADAIR, John Eric. Leadership for innovation: How to organize team creativity and harvest ideas. Kogan Page Publishers, 2007.

ADEGBESAN, J. A. On the origins of competitive advantage: Strategic factor markets and heterogeneous resource complementarity. Academy of Management Review, v. 34, n. 3, p. 463-475, 2009.

ADNER, R.; ZEMSKY, P. A demand-based perspective on sustainable competitive advantage. Strategic Management Journal, v. 27, n. 3, p. 215-239, Mar 2006.

AHEARNE, Michael; MATHIEU, John; RAPP, Adam. To empower or not to empower your sales force? An empirical examination of the influence of leadership empowerment behavior on customer satisfaction and performance. Journal of Applied psychology, v. 90, n. 5, p. 945, 2005.

AMABILE, Teresa M. A model of creativity and innovation in organizations. Research in organizational behavior, v. 10, n. 1, p. 123-167, 1988.

AMABILE, Teresa M. Motivational synergy: Toward new conceptualizations of intrinsic and extrinsic motivation in the workplace. Human resource management review, v. 3, n. 3, p. 185-201, 1993.

AMBROSINI, Véronique; BOWMAN, Cliff. What are dynamic capabilities and are they a useful construct in strategic management?. International journal of management reviews, v. 11, n. 1, p. 29-49, 2009.

AMUNDSEN, Stein; MARTINSEN, Øyvind L. Empowering leadership: Construct clarification, conceptualization, and validation of a new scale. The Leadership Quarterly, v. 25, n. 3, p. 487-511, 2014.

AMUNDSEN, Stein; MARTINSEN, Øyvind L. Linking empowering leadership to job satisfaction, work effort, and creativity: The role of self-leadership and psychological empowerment. Journal of Leadership \& Organizational Studies, v. 22, n. 3, p. 304-323, 2015. 
ANDREEVA, T. E.; CHAYKA, V. A. Dynamic capabilities: What they need to be dynamic? Discussion Paper \#10(E)-2006. Institute of Management, St. Petersburg State University: SPb., 2006.

ANDREWS, Kenneth R. The concept of corporate strategy. New York, 1971.

ANTONAKIS, J. Transformational and Charismatic Leaderships. In The Nature of Leadership, Sage Publication, p. 256-288, 2012.

ANTONAKIS, J.; BASTARDOZ, N.; LIU, Y.; SCHRIESHEIM, C. A. What makes articles highly cited? The Leadership Quarterly, v. 25, n.1, p. 152-179, 2014.

ANTONAKIS, J.; HOUSE, R. J. An analysis of the full-range leadership theory: The way forward. In Avolio, B. J.; Yammarino, F. J. (Eds.). Transformational and charismatic leadership: The road ahead, p. 3-34. Amsterdam: JAI Press, 2002.

ANTONAKIS, J.; HOUSE, R. J. Instrumental leadership: Measurement and extension of transformational-transactional leadership theory. The Leadership Quarterly, v. 25, n. 4, p. 746-771, 2014.

ANTONAKIS, John; BASTARDOZ, Nicolas; JACQUART, Philippe \& SHAMIR, Boas. Charisma: An ill-defined and ill-measured gift. Annual Review of Organizational Psychology and Organizational Behavior, v. 3, p. 293-319, 2016.

ANTONAKIS, John; CIANCIOLO, Anna T.; STERNBERG, Robert J. Leadership: Past, present, and future. The nature of leadership, p. 3-15, 2004.

ANTONAKIS, John; DAY, David V. (Ed.). The nature of leadership. Sage publications, 2017.

ANTONAKIS, John; HOUSE, Robert J. Instrumental leadership: Measurement and extension of transformational-transactional leadership theory. The Leadership Quarterly, v. 25, n. 4, p. 746-771, 2014.

AREND, Richard J.; BROMILEY, Philip. Assessing the dynamic capabilities view: spare change, everyone? STRATEGIC ORGANIZATION, v. 7, n. 1, p. 75-90, 2009.

ARMENAKIS, Achilles A.; HARRIS, Stanley G.; MOSSHOLDER, Kevin W. Creating readiness for organizational change. Human relations, v. 46, n. 6, p. 681-703, 1993. 
ARNOLD, Josh A.; ARAD, Sharon; RHOADES, Jonathan A.; DRASGOW, Fritz. The empowering leadership questionnaire: The construction and validation of a new scale for measuring leader behaviors. Journal of Organizational Behavior, v. 21, n. 3, p. 249-269, 2000.

AVOLIO, Bruce J.; BASS, Bernard M. Transformational leadership, charisma, and beyond. 1988.

BANDURA, Albert. Self-efficacy: toward a unifying theory of behavioral change. Psychological review, v. 84, n. 2, p. 191, 1977.

BANDURA, Albert. Social foundation of thought and action: A social-cognitive view. Englewood Cliffs, 1986.

BARNEY, J. B. Gaining and Sustaining Competitive Advantage. 4. ed. Pearson Education, 2014.

BARNEY, J. B.; HESTERLY, W. S. Administração estratégica e vantagem competitiva - conceitos e casos. 5. ed. São Paulo: Pearson Education do Brasil, 2017.

BARNEY, J. Firm resources and sustained competitive advantage. Journal of management, v. 17, n. 1, p. 99-120, 1991.

BARRETO, I. Dynamic capabilities: a review of past research and an agenda for the future. Journal of Management, v. 36, n. 1, p. 256-280, 2010.

BARRICK, M.R., THURGOOD, G.R., SMITH, T.A., \& COURTRIGHT, S.H.. A model of collective organizational engagement: motivational antecedents, strategic implementation as a moderator, and firm level performance. Academy of Management Journal, 58: 111-135. 2015.

BARTUNEK, Jean M.; SPREITZER, Gretchen M. The interdisciplinary career of a popular construct used in management: Empowerment in the late 20th century. Journal of Management Inquiry, v. 15, n. 3, p. 255-273, 2006.

BASS, B. M. Leadership and performance beyond expectations. New York, NY: Free Press, 1985.

BASS, B. M. Transformational Leadership: Industrial, Military, and Educational Impact. Mahwah, NJ: Lawrence Erlbaum Associates. 1998.

BASS, B. M.; RIGGIO, R. E. Transformational Leadership. Mahwah, NJ: Lawrence Erlbaum, 2. ed., 2006. 
BASS, B. M; AVOLIO, B. J. The implications of transactional and transformational leadership for individual, team, and organizational development. Research in Organizational Change and Development, v. 4, p. 231-272, 1990. BASS, Bernard M.; BASS, Ruth. The Bass handbook of leadership: Theory, research, and managerial applications. Simon and Schuster, 2009.

BASS, B.M. From Transactional do Transformational Leadership: Learning to Share the Vision. Organizational Dynamics, v.19, p.19-31, 1990.

BASS, Bernard M.; STEIDLMEIER, Paul. Ethics, character, and authentic transformational leadership behavior. The leadership quarterly, v. 10, n. 2, p. 181-217, 1999.

BIRKINSHAW, Julian; GIBSON, Christina B. Building an ambidextrous organisation. Advanced Institute of Management Research Paper, n. 003, 2004.

BLYLER, M.; COFF, R. W. Dynamic capabilities, social capital, and rent appropriation: ties that split pies. Strategic Management Journal, v. 24, n. 7, p. 677-686, Jul 2003.

BOAL, K. B. Strategic leadership, organizational learning, and network ties. In HOOIJBERG, R.; HUNT, J.; ANTONAKIS, J.; BOAL, K.; LANE, N. (Eds.). Being there even when you are not: Leading through strategy, structures, and systems, p. 69-86. Amsterdam: Elsevier, 2007.

BONARDI, J.; HITT, M. A.; VERA, D.; WITHERS, M. C. Chamada de artigos em Strategic Leadership and Strategic Management. The Leadearship Quarterly. https://www.journals.elsevier.com/the-leadership-quarterly/call-forpapers/strategic-leadership-and-strategic-management . Acesso em 07/09/2018 BRANDENBURGER, A. M.; STUART, H. W. Value-based Business Strategy. Journal of Economics \& Management Strategy, v. 5, n. 1, p. 5-24, 1996.

BRITO, Eliane Pereira Zamith; BRITO, Luiz Artur Ledur; MORGANTI, Fábio. Inovação e o desempenho empresarial: lucro ou crescimento?. 2009.

BRITO, R. P.; BRITO, L. L. Vantagem competitiva, criação de valor e seus efeitos sobre o desempenho. RAE - Revista de Administração de Empresas, v. 52, p. 70-84, 2012.

BROWN, Michael E.; TREVIÑO, Linda K. Ethical leadership: A review and future directions. The leadership quarterly, v. 17, n. 6, p. 595-616, 2006. 
BRYMAN, Alan. Charisma and leadership in organizations. Sage Pubns, 1992.

BURKE, C. Shawn; PIERCE, Linda G.; SALAS, Eduardo (Ed.). Understanding adaptability: A prerequisite for effective performance within complex environments. Emerald Group Publishing, 2006.

BURNS, J.M. Leadership, Harper Collins Publishers, Inc., 1978.

CAILLIER, James Gerard. Do transformational leaders affect turnover intentions and extra-role behaviors through mission valence?. The American Review of Public Administration, v. 46, n. 2, p. 226-242, 2016.

CARSON, Jay B.; TESLUK, Paul E.; MARRONE, Jennifer A. Shared leadership in teams: An investigation of antecedent conditions and performance. Academy of management Journal, v. 50, n. 5, p. 1217-1234, 2007.

CASSEL, Claes; HACKL, Peter; WESTLUND, Anders H. Robustness of partial least-squares method for estimating latent variable quality structures. Journal of applied statistics, v. 26, n. 4, p. 435-446, 1999.

CAVAZOTTE, Flavia; MORENO, Valter; LASMAR, Luis Cesar Chehab.

Enabling customer satisfaction in call center teams: the role of transformational leadership in the service-profit chain. The Service Industries Journal, v. 40, n. 5, p. 380-393, 2020.

CHATAIN, O. Value creation, competition, and performance in buyer- supplier relationships. Strategic Management Journal, v. 32, n. 1, p. 76-102, 2011.

CHEN, G.; SHARMA, P. N.; EDINGER, S. K.; SHAPIRO, D. L.; FARH, J. L. Motivating and demotivating forces in teams: cross-level influences of empowering leadership and relationship conflict. Journal of Applied Psychology, v. 96, n. 3, p. 541, 2011.

CHEONG, Minyoung; YAMMARINO, F. J.; DIONNE, S. D.; SPAIN, S. M.; TSAI, C. Y. A review of the effectiveness of empowering leadership. The Leadership Quarterly, v. 30, n. 1, p. 34-58, 2019.

CHIN, Wynne W. Newsted, P. r. 1999. Structural equation modelling analysis with small samples using partial least squares. Statistical Strategies for Small Sample Research, p. 307-339, 1999.

CHIN, Wynne W. The partial least squares approach to structural equation modeling. Modern methods for business research, v. 295, n. 2, p. 295-336, 1998. 
COFF, R. W. The coevolution of rent appropriation and capability development. Strategic Management Journal, v. 31, n. 7, p. 711-733, 2010.

COFF, R. W. When competitive advantage doesn't lead to performance: The resource-based view and stakeholder bargaining power. Organization Science, v. 10, n. 2, p. 119-133, 1999.

COLBERT, A. E.; KRISTOF-BROWN, A. L.; BRADLEY, B. H.; BARRICK, M. R. CEO transformational leadership: The role of goal importance congruence in top management teams. Academy of management journal, v. 51, n. 1, p. 81-96, 2008.

COLLIS, D. J. Research note: how valuable are organizational capabilities? Strategic Management Journal, v. 15, n. S1, p. 143-152, 1994.

CONGER, J. A.; KANUNGO, R. N. The empowerment process: Integrating theory and practice. Academy of Management Review, v. 13, n. 3, p. 471-482, 1988.

CONGER, Jay A. Charismatic and transformational leadership in organizations: An insider's perspective on these developing streams of research. The leadership quarterly, v. 10, n. 2, p. 145-179, 1999.

CONGER, Jay A. Leadership: The art of empowering others. Academy of Management Perspectives, v. 3, n. 1, p. 17-24, 1989.

CONGER, Jay A.; KANUNGO, Rabindra N. Charismatic leadership in organizations. Sage Publications, 1998.

CONGER, Jay A.; KANUNGO, Rabindra N. Charismatic leadership: The elusive factor in organizational effectiveness. Jossey-Bass, 1988.

DANNEELS, Erwin. Firm Resources \& Cognition: Setting a Research Agenda. In: Academy of Management Proceedings. Briarcliff Manor, NY 10510: Academy of Management, 2015. p. 12490.

DAVIES, James C. Charisma in the 1952 Campaign. American Political Science Review, v. 48, n. 4, p. 1083-1102, 1954.

DAY, David V.; ANTONAKIS, John. Leadership: Past, present, and future. The nature of leadership, p. 3-25, 2012.

DINH, J. E., LORD, R. G., GARDNER, W. L., MEUSER, J. D., LIDEN, R. C., \& HU, J. Leadership theory and research in the new millennium: Current theoretical trends and changing perspectives. The Leadership Quarterly, 25(1), 36-62. 2014. 
DIXON, Sarah; MEYER, Klaus; DAY, Marc. Building dynamic capabilities of adaptation and innovation: A study of micro-foundations in a transition economy. Long Range Planning, v. 47, n. 4, p. 186-205, 2014.

DOWNTON, James V. Rebel leadership: Commitment and charisma in the revolutionary process. Free Press, 1973.

DOZ, Yves L.; KOSONEN, Mikko. Embedding strategic agility: A leadership agenda for accelerating business model renewal. Long range planning, v. 43, n. 2-3, p. 370-382, 2010.

EDMONDSON, Amy C. Teamwork on the fly. Harvard business review, v. 90, n. 4, p. 72-80, 2012.

EISENHARDT, K. M.; MARTIN, J. A. Dynamic capabilities: what are they? Strategic Management Journal, v. 21, n. 10/11, p. 1105-1121, 2000.

ELKINS, Teri; KELLER, Robert T. Leadership in research and development organizations: A literature review and conceptual framework. The leadership quarterly, v. 14, n. 4-5, p. 587-606, 2003.

ETZIONI, Amitai. Modern Organizations. Prentice-Hall, Englewood Cliffs, NJ, 1964.

ETZIONI, Amitai. Comparative analysis of complex organizations. Free Press, New York, NY, 1961.

FAINSHMIDT, S.; PEZESHKAN, A.; LANCE FRAZIER, M.; NAIR, A.; MARKOWSKI, E. Dynamic capabilities and organizational performance: a meta- analytic evaluation and extension. Journal of Management Studies, v. 53, n. 8, p. 1348-1380, 2016.

FANG, Eric Er; ZOU, Shaoming. Antecedents and consequences of marketing dynamic capabilities in international joint ventures. Journal of International Business Studies, v. 40, n. 5, p. 742-761, 2009.

FERNANDEZ, Sergio; MOLDOGAZIEV, Tima. Empowering public sector employees to improve performance: Does it work?. The American Review of Public Administration, v. 41, n. 1, p. 23-47, 2011.

FLEISHMAN, E. A.; MUMFORD, M. D.; ZACCARO, S. J.; LEVIN, K. Y.; KOROTKIN, A. L.; HEIN, M. B. Taxonomic efforts in the description of leader behavior: A synthesis and functional interpretation. The Leadership Quarterly, v. 2, n. 4, p. 245-287, 1991. 
FORD, Robert C.; FOTTLER, Myron D. Empowerment: A matter of degree. Academy of Management Perspectives, v. 9, n. 3, p. 21-29, 1995.

FORNELL, Claes; LARCKER, David F. Evaluating structural equation models with unobservable variables and measurement error. Journal of marketing research, v. 18, n. 1, p. 39-50, 1981.

FRIEDRICH, Carl J. Political leadership and the problem of the charismatic power. The Journal of Politics, v. 23, n. 1, p. 3-24, 1961.

GALUNIC, D. Charles; RODAN, Simon. Resource recombinations in the firm: Knowledge structures and the potential for Schumpeterian innovation. Strategic management journal, v. 19, n. 12, p. 1193-1201, 1998.

GIROD, Stéphane JG; WHITTINGTON, Richard. Reconfiguration, restructuring and firm performance: Dynamic capabilities and environmental dynamism. Strategic Management Journal, v. 38, n. 5, p. 1121-1133, 2017.

GLICK, William H. Conceptualizing and measuring organizational and psychological climate: Pitfalls in multilevel research. Academy of management review, v. 10, n. 3, p. 601-616, 1985.

GRANT, Adam M. Leading with meaning: Beneficiary contact, prosocial impact, and the performance effects of transformational leadership. Academy of Management Journal, v. 55, n. 2, p. 458-476, 2012.

GREGERSEN, S.; VINCENT- HÖPER, S.; NIENHAUS, A. The Relation Between Leadership and Perceived Well- Being: What Role Does Occupational Self- Efficacy Play? Journal of Leadership Studies, v. 8, n. 2, p. 6-18, 2014.

GREWAL, Rajdeep; SLOTEGRAAF, Rebecca J. Embeddedness of organizational capabilities. Decision Sciences, v. 38, n. 3, p. 451-488, 2007.

GUMUSLUOGLU, Lale; ILSEV, Arzu. Transformational leadership, creativity, and organizational innovation. Journal of business research, v. 62, n. 4, p. 461473, 2009.

HACKMAN, J. R.; WAGEMAN, R. A theory of team coaching. Academy of Management Review, v. 30, n. 2, p. 269-287, 2005.

HAIR, J. F. J. F.; BLACK, W. C.; BABIN, B. J.; \& ANDERSON, R. E. Multivariate data analysis. Upper Saddle River, NJ [etc.]. Pearson Prentice Hall, New York, NY: Macmillan, v. 24, p. 899, 2009. 
HASSAN, S.; MAHSUD, R.; YUKL, G.; \& PRUSSIA, G. E. Ethical and empowering leadership and leader effectiveness. Journal of Managerial Psychology, 2013.

HEIMERIKS, Koen H.; SCHIJVEN, Mario; GATES, Stephen. Manifestations of higher-order routines: The underlying mechanisms of deliberate learning in the context of postacquisition integration. Academy of Management Journal, v. 55, n. 3, p. 703-726, 2012.

HELFAT, Constance E.; WINTER, Sidney G. Untangling dynamic and operational capabilities: Strategy for the $(\mathrm{N})$ ever- changing world. Strategic management journal, v. 32, n. 11, p. 1243-1250, 2011.

HENNESSEY, Beth; MORAN, Seana; ALTRINGER, Beth; AMABILE, Teresa M. Extrinsic and intrinsic motivation. Wiley encyclopedia of management, p. 14, 2015.

HILL, Frances; HUQ, Rozana. Employee empowerment: conceptualizations, aims

and outcomes. Total Quality Management \& Business Excellence, v. 15, n. 8, p. 1025-1041, 2004.

HOOIJBERG, R.; HUNT, J. G.; ANTONAKIS, J.; BOAL, K. B.; LANE, N. (Eds.) Being there even when you are not. Emerald Group Publishing Limited, 2007.

HOOIJBERG, Robert; HUNT, James G. Jerry; DODGE, George E. Leadership complexity and development of the leaderplex model. Journal of management, v. 23, n. 3, p. 375-408, 1997.

HOUSE, R. J. A 1976 Theory of Charismatic Leadership-Leadership: The Cutting Edge. JG Hunt, LL Larson (red.), Carbondale, 1977.

HOUSE, Robert J. A path goal theory of leader effectiveness. Administrative science quarterly, p. 321-339, 1971.

HOUSE, Robert J. Path-goal theory of leadership: Lessons, legacy, and a reformulated theory. The leadership quarterly, v. 7, n. 3, p. 323-352, 1996.

HUGHES, D. J.; LEE, A.; TIAN, A. W.; NEWMAN, A.; LEGOOD, A. Leadership, creativity, and innovation: A critical review and practical recommendations. The Leadership Quarterly, v. 29, n. 5, p. 549-569, 2018.

HUMPHREY, Stephen E.; NAHRGANG, Jennifer D.; MORGESON, Frederick P. Integrating motivational, social, and contextual work design features: a meta- 
analytic summary and theoretical extension of the work design literature. Journal of applied psychology, v. 92, n. 5, p. 1332, 2007.

HUNT, James G. Transformational/charismatic leadership's tranformation of the field: An historical essay. The Leadership Quarterly, v. 10, n. 2, p. 129-144, 1999.

JAMES, Lawrence R.; DEMAREE, Robert G.; WOLF, Gerrit. rwg: An assessment of within-group interrater agreement. Journal of applied psychology, v. 78, n. 2, p. 306, 1993.

JIANG, Yuan; CHEN, Chao C. Integrating knowledge activities for team innovation: Effects of transformational leadership. Journal of Management, v. 44, n. 5, p. 1819-1847, 2018.

JUDGE, T. A.; PICCOLO, R. F. Transformational and transactional leadership: a meta-analytic test of their relative validity. Journal of Applied Psychology, v. 89, n. 5, p. 755, 2004.

JUDGE, T. A.; PICCOLO, R. F.; ILIES, R. The Forgotten Ones? The Validity of consideration and Initiating Structure in Leadership Research. Journal of Applied Psychology, v. 89, n. 1, p. 36-51, 2004.

JUNG, Dong I.; AVOLIO, Bruce J. Effects of leadership style and followers' cultural orientation on performance in group and individual task conditions. Academy of management journal, v. 42, n. 2, p. 208-218, 1999.

JUNG, Dong I.; CHOW, Chee; WU, Anne. The role of transformational leadership in enhancing organizational innovation: Hypotheses and some preliminary findings. The leadership quarterly, v. 14, n. 4-5, p. 525-544, 2003.

JUNG, Dongil Don; WU, Anne; CHOW, Chee W. Towards understanding the direct and indirect effects of CEOs' transformational leadership on firm innovation. The leadership quarterly, v. 19, n. 5, p. 582-594, 2008.

KANFER, Ruth; FRESE, Michael; JOHNSON, Russell E. Motivation related to work: A century of progress. Journal of Applied Psychology, v. 102, n. 3, p. 338, 2017.

KANTER, Rosabeth Moss. The change masters New York-Simon and Schuster. KanterThe Change Masters 1983, 1983.

KAO, P. J.; PAI, P.; LIN, T.; ZHONG, J. Y. How transformational leadership fuels employees' service innovation behavior. The Service Industries Journal, v. 35, n. 7-8, p. 448-466, 2015.

KATZ, Daniel; KAHN, Robert L. The social psychology of 
KEISTER, Lisa A. The one percent. Annual Review of Sociology, v. 40, p. 347$367,2014$.

KIRKMAN, Bradley L.; ROSEN, Benson. A model of work team empowerment. Research in organizational change and development, v. 10, n. 1, p. 131-167, 1997.

KOGUT, Bruce; ZANDER, Udo. What firms do? Coordination, identity, and learning. Organization science, v. 7, n. 5, p. 502-518, 1996.

LAM, Catherine K.; HUANG, Xu; CHAN, Simon CH. The threshold effect of participative leadership and the role of leader information sharing. Academy of Management Journal, v. 58, n. 3, p. 836-855, 2015.

LAUREIRO- MARTÍNEZ D.; BRUSONI S. Cognitive flexibility and adaptive decision- making: Evidence from a laboratory study of expert decision makers. Strategic Management Journal. v. 39, n. 4, p.: 1031-1058, 2018.

LAVIE, Dovev. Capability reconfiguration: An analysis of incumbent responses to technological change. Academy of management review, v. 31, n. 1, p. 153$174,2006$.

LEFEBVRE, Elisabeth; LEFEBVRE, Louis A. Firm innovativeness and CEO characteristics in small manufacturing firms. Journal of Engineering and Technology Management, v. 9, n. 3-4, p. 243-277, 1992.

LEPAK, D. P.; SMITH, K. G.; TAYLOR, M. S. Value creation and value capture: a multilevel perspective. Academy of Management Review, v. 32, n. 1, p. 180194, 2007.

LEVINTHAL, Daniel A.; MARCH, James G. The myopia of learning. Strategic management journal, v. 14, n. S2, p. 95-112, 1993.

LIPPMAN, S. A.; RUMELT, R. P. A bargaining perspective on resource advantage. Strategic Management Journal, v. 24, n.11; p. 1069-1086, 2003.

LOCKE, Edwin A.; LATHAM, Gary P. A theory of goal setting \& task performance. Prentice-Hall, Inc, 1990.

LORD, Robert G. Functional leadership behavior: Measurement and relation to social power and leadership perceptions. Administrative science quarterly, p. 114-133, 1977.

LOWE, Kevin B.; GALEN KROECK, K.; SIVASUBRAMANIAM, N. Effectiveness correlates of transformational and transactional leadership: A meta-analytic. Leadership quarterly, v. 7, n. 3, p. 385, 1996. 
LOWE, Kevin B.; GARDNER, William L. Ten years of the leadership quarterly: Contributions and challenges for the future. The Leadership Quarterly, v. 11, n. 4, p. 459-514, 2000.

MANZ, C. C.; BASTIEN, D. T.; HOSTAGER, T. J.; \& SHAPIRO, G. L. Leadership and innovation: A longitudinal process view. Research on the management of innovation: The Minnesota studies, p. 613-636, 1989.

MANZ, Charles C. Self-leadership: Toward an expanded theory of self-influence processes in organizations. Academy of Management review, v. 11, n. 3, p. 585600, 1986.

MANZ, Charles C.; SIMS JR, Henry P. Self-management as a substitute for leadership: A social learning theory perspective. Academy of Management review, v. 5, n. 3, p. 361-367, 1980.

MARCH J. G. Exploration and exploitation in organizational learning. Organization Science, v. 2, n. 1, p. 71-87. 1991.

MARCH, J. G. Rationality, foolishness, and adaptive intelligence. Strategic Management Journal, v. 27, n. 3, p. 201-214. 2006.

MEIRELlES, D. S.; CAMARGO, A. A. B. Capacidades Dinâmicas: O Que São e Como Identificá-las? RAC, v. 18, Edição Especial, art. 3, p. 41-64, 2014.

Moreno, V., CARVAlho, W. D. S., \& CAVAZOTTE, F. Does Business Intelligence Leverage Dynamic and Operational Capabilities? Impacts on Marketing Processes in Telecom Companies. In Americas Conference On Information Systems (AMCIS). Association for Information Systems, 2018.

MORGESON, F. P. The external leadership of self-managing teams: intervening in the context of novel and disruptive events. Journal of Applied Psychology, v. 90, n. 3, p. 497, 2005.

MORGESON, F. P.; DERUE, D. S.; KARAM, E. P. Leadership in teams: A functional approach to understanding leadership structures and processes. Journal of Management, v. 36, n. 1, p. 5-39, 2010.

MUMFORD, M. D. Pathways to outstanding leadership: A comparative analysis of charismatic, ideological, and pragmatic leaders. Lawrence Erlbaum Associates Publishers, 2006.

MUMFORD, M. D.; SCOTT, G. M.; GADDIS, B.; \& STRANGE, J. M. Leading creative people: Orchestrating expertise and relationships. The leadership quarterly, v. 13, n. 6, p. 705-750, 2002. 
NADLER, D. A.; TUSHMAN, M. L. Beyond the charismatic leader: Leadership and organizational change. California Management Review, v. 32, n. 2, p. 7797, 1990.

NEWBERT, S. L. Value, rareness, competitive advantage, and performance: a conceptual- level empirical investigation of the resource- based view of the firm. Strategic Management Journal, v. 29, n. 7, p. 745-768, 2008.

NG, Thomas WH. Transformational leadership and performance outcomes: Analyses of multiple mediation pathways. The Leadership Quarterly, v. 28, n. 3, p. 385-417, 2017.

NORTHOUSE, P.G. Leadership: Theory and Practice, 7. ed. Thousand Oaks, California: Sage Publications, 2015.

organizations. New York: Wiley, 1978.

PABLO, Amy L. et al. Identifying, enabling and managing dynamic capabilities in the public sector. Journal of management studies, v. 44, n. 5, p. 687-708, 2007.

PALANSKI, Michael E.; YAMMARINO, Francis J. Integrity and leadership: A multi-level conceptual framework. The Leadership Quarterly, v. 20, n. 3, p. 405-420, 2009.

PAN, Wen; SUN, Li-Yun; CHOW, Irene Hau Siu. Leader-member exchange and employee creativity: Test of a multilevel moderated mediation model. Human Performance, v. 25, n. 5, p. 432-451, 2012.

PARKER, Sharon K.; WALL, Toby D.; CORDERY, John L. Future work design research and practice: Towards an elaborated model of work design. Journal of occupational and organizational psychology, v. 74, n. 4, p. 413-440, 2001.

PATNAYAKUNI, Ravi; RUPPEL, Cynthia P. Managing the complementarity of knowledge integration and process formalization for systems development performance. Journal of the association for information systems, v. 7, n. 1, p. 21, 2006.

PAVLOU, Paul A.; EL SAWY, Omar A. Understanding the elusive black box of dynamic capabilities. Decision sciences, v. 42, n. 1, p. 239-273, 2011.

PEARCE, Craig L.; SIMS JR, Henry P. Vertical versus shared leadership as predictors of the effectiveness of change management teams: An examination of aversive, directive, transactional, transformational, and empowering leader 
behaviors. Group dynamics: Theory, research, and practice, v. 6, n. 2, p. 172, 2002.

PEARCE, Craig L.; SIMS JR, Henry P.; COX, Jonathan F.; BALL, Gail; SCHNELL, Eugene; SMITH, Ken A.; TREVINO, Linda. Transactors, transformers and beyond: A multi-method development of a theoretical typology of leadership. Journal of Management development, v. 22, n. 4, p. 273-307, 2003.

PENROSE, E. The Theory of the Growth of the Firm. 4. ed. London, Oxford University Press, 2006 (First published 1959).

PETERAF, Margaret; DI STEFANO, Giada; VERONA, Gianmario. The elephant in the room of dynamic capabilities: Bringing two diverging conversations together. Strategic management journal, v. 34, n. 12, p. 1389-1410, 2013.

PETTIGREW, Andrew M. Context and action in the transformation of the firm. Journal of management studies, v. 24, n. 6, p. 649-670, 1987.

PEZESHKAN, A.; FAINSHMIDT, S.; NAIR, A.; FRAZIER, M. L.; MARKOWSKI, E. An empirical assessment of the dynamic capabilitiesperformance relationship. Journal of Business Research, v. 69, n. 8, p. 29502956, 2016.

PITELIS, Christos N.; WAGNER, Joachim D. Strategic Shared Leadership and Organizational Dynamic Capabilities. The Leadership Quarterly, v. 30, n. 2, p. 233-242, 2019.

PORTER. M. E. Vantagem Competitiva: Criando e Sustentando um Desempenho Superior. Rio de Janeiro: Elsevier, 1989.

PRIEM, R. L. A consumer perspective on value creation. Academy of Management Review, v. 32, n. 1, p. 219-235, 2007.

QUINN, J. B. Strategies for change: Logical incrementalism. Irwin Professional Publishing, 1980.

RAFFERTY, Alannah E.; GRIFFIN, Mark A. Dimensions of transformational leadership: Conceptual and empirical extensions. The leadership quarterly, v. 15, n. 3, p. 329-354, 2004.

RAJAPATHIRANA, RP Jayani; HUI, Yan. Relationship between innovation capability, innovation type, and firm performance. Journal of Innovation \& Knowledge, v. 3, n. 1, p. 44-55, 2018. 
REEVES, M.; DEIMLER, M. Zdolność do adaptacji źródłem nowej przewagi konkurencyjnej,". Harvard Business Review Polska, n. 12-2012, 2011.

RINGLE, Christian M.; WENDE, Sven; WILL, Alexander. Smart pls 2.0 m3, university of hamburg. '^'eds.'): Book Smart Pls, v. 2, p. M3, 2005.

ROSING, Kathrin; FRESE, Michael; BAUSCH, Andreas. Explaining the heterogeneity of the leadership-innovation relationship: Ambidextrous leadership. The leadership quarterly, v. 22, n. 5, p. 956-974, 2011.

ROWOLD J. Instrumental Leadership: Extending the TransformationalTransactional Leadership Paradigm. German Journal of Human Resource Management, v. 28, n. 3, p. 367-390, 2014.

RUMELT R.P. Towards a strategic theory of the firm. In Competitive Strategic Management, LAMB R.B. (Ed.), p. 556-570. Prentice-Hall: Englewood Cliffs, NJ, 1984.

RUMELT, R. P.; SCHENDEL, D. E.; TEECE, D. J. Fundamental Issues in

Strategy: A Research Agenda. Harvard Business School Press: Boston, MA, 1994.

SCHILKE, Oliver. On the contingent value of dynamic capabilities for competitive advantage: The nonlinear moderating effect of environmental dynamism. Strategic management journal, v. 35, n. 2, p. 179-203, 2014.

SCOTT, Susanne G.; BRUCE, R. A. Creating innovative behavior among R\&D professionals: the moderating effect of leadership on the relationship between problem-solving style and innovation. In: Proceedings of 1994 IEEE International Engineering Management Conference-IEMC'94. IEEE, 1994. p. 48-55.

SEARLE, Travis P.; BARBUTO JR, John E. A multilevel framework: Expanding and bridging micro and macro levels of positive behavior with leadership. Journal of Leadership \& Organizational Studies, v. 20, n. 3, p. 274-286, 2013. SHAMIR, Boas; HOUSE, Robert J.; ARTHUR, Michael B. The motivational effects of charismatic leadership: A self-concept based theory. Organization science, v. 4, n. 4, p. 577-594, 1993.

SHAPIRO, C. The theory of business strategy. The Rand Journal of Economics, v. 20, n. 1, p. 125-137, 1989. 
SHARMA, Payal Nangia; KIRKMAN, Bradley L. Leveraging leaders: A literature review and future lines of inquiry for empowering leadership research. Group \& Organization Management, v. 40, n. 2, p. 193-237, 2015.

SHAWN BURKE, C.; PIERCE, Linda G.; SALAS, Eduardo (Ed.). Understanding adaptability: A prerequisite for effective performance within complex environments. Emerald Group Publishing Limited, 2006.

SHIN, Shung Jae; ZHOU, Jing. Transformational leadership, conservation, and creativity: Evidence from Korea. Academy of management Journal, v. 46, n. 6, p. 703-714, 2003.

SPREITZER, Gretchen M. Psychological empowerment in the workplace: Dimensions, measurement, and validation. Academy of management Journal, v. 38, n. 5, p. 1442-1465, 1995.

SPREITZER, Gretchen M.; DONESON, David. Musings on the past and future of employee empowerment. Handbook of organizational development, v. 4, p. 5$10,2005$.

SRIVASTAVA, Abhishek; BARTOL, Kathryn M.; LOCKE, Edwin A. Empowering leadership in management teams: Effects on knowledge sharing, efficacy, and performance. Academy of management journal, v. 49, n. 6, p. 1239-1251, 2006.

STADLER, Christian; HELFAT, Constance E.; VERONA, Gianmario. The impact of dynamic capabilities on resource access and development. Organization science, v. 24, n. 6, p. 1782-1804, 2013.

STOGDILL, Ralph M. Handbook of leadership: A survey of theory and research. Free Press, 1974

STURM, R. E., VERA, D., \& CROSSAN, M. The entanglement of leader character and leader competence and its impact on performance. The Leadership Quarterly, 28 (3), 349-366. 2017.

TEECE, D. J. Economic analysis and strategic management. California Management Review. v. 26, n. 3, p. 87, 1984.

TEECE, D. J. Explicating dynamic capabilities: the nature and microfoundations of (sustainable) enterprise performance. Strategic Management Journal, v. 28, n. 13, p. 1319-1350, 2007.

TEECE, D. J.; PISANO, G.; SHUEN, A. Dynamic capabilities and strategic management. Strategic Management Journal, v. 18, n. 7, p. 509-533, 1997. 
TEKLEAB, Amanuel G. et al. Are we on the same page? Effects of selfawareness of empowering and transformational leadership. Journal of Leadership \& Organizational Studies, v. 14, n. 3, p. 185-201, 2008.

TENENHAUS, Michel; HANAFI, Mohamed. A bridge between PLS path modeling and multi-block data analysis. In: Handbook of partial least squares. Springer, Berlin, Heidelberg, 2010. p. 99-123.

THOMAS, K. W.; VELTHOUSE, B. A. Cognitive elements of empowerment: An "interpretive" model of intrinsic task motivation. Academy of Management Review, v. 15, n. 4, p. 666-681, 1990.

THORESEN, Carl E.; MAHONEY, Michael J. Behavioral self-control. Holt McDougal, 1974.

TIERNEY, Pamela; FARMER, Steven M.; GRAEN, George B. An examination of leadership and employee creativity: The relevance of traits and relationships. Personnel psychology, v. 52, n. 3, p. 591-620, 1999.

TUCKER, Robert C. The theory of charismatic leadership. Daedalus, p. 731-756, 1968.

TUSHMAN, Michael; NADLER, David. Organizing for innovation. California management review, v. 28, n. 3, p. 74-92, 1986.

UHL-BIEN, Mary; ARENA, Michael. Leadership for organizational adaptability: A theoretical synthesis and integrative framework. The Leadership Quarterly, v. 29, n. 1, p. 89-104, 2018.

UHL-BIEN, Mary; MARION, Russ. Complexity leadership in bureaucratic forms of organizing: A meso model. The Leadership Quarterly, v. 20, n. 4, p. 631$650,2009$.

UHL-BIEN, Mary; MARION, Russ; MCKELVEY, Bill. Complexity leadership theory: Shifting leadership from the industrial age to the knowledge era. The leadership quarterly, v. 18, n. 4, p. 298-318, 2007.

URBACH, Nils; AHLEMANN, Frederik. Structural Equation Modeling in Information Systems Research Using Partial Least Squares. Journal of Information Technology Theory and Application, v. 11, n. 2, p. 5-40, 2010.

VAN DE VEN, Andrew H. Central problems in the management of innovation. Management science, v. 32, n. 5, p. 590-607, 1986.

VINZI, Vincenzo Esposito; TRINCHERA, Laura; AMATO, Silvano. PLS path modeling: from foundations to recent developments and open issues for model 
assessment and improvement. In: Handbook of partial least squares. Springer, Berlin, Heidelberg, 2010. p. 47-82.

VROOM, Victor Harold. Work and motivation. 1964.

WANG, C. L.; AHMED, P. K. Dynamic capabilities: a review and research agenda. International Journal of Management Reviews, v. 9, n. 1, p. 31-51, 2007.

WEBER, Max. The Theory of Social and Economic Organizations, ed. Parsons, T., trans, 1947.

WEBER, Max. On charisma and institution building. University of Chicago Press, 1968.

WEICK K. E; SUTCLIFFE K. M. Mindfulness and the Quality of Organizational Attention. Organization Science, v. 17, n. 4, p. 514, 2006;

WERNERFELT, B. A resource- based view of the firm. Strategic Management Journal, v. 5, n. 2, p. 171-180, 1984.

WETZELS, Martin; ODEKERKEN-SCHRÖDER, Gaby; VAN OPPEN, Claudia. Using PLS path modeling for assessing hierarchical construct models: Guidelines and empirical illustration. MIS quarterly, p. 177-195, 2009.

WINTER, S. G. Understanding dynamic capabilities. Strategic Management Journal, v. 24, p. 991-995, 2003.

WINTER, Sidney G. Capabilities: Their origins and ancestry. Journal of management studies, v. 49, n. 8, p. 1402-1406, 2012.

WOODMAN, Richard W.; SAWYER, John E.; GRIFFIN, Ricky W. Toward a theory of organizational creativity. Academy of management review, v. 18, n. 2, p. 293-321, 1993.

WORLEY, Christopher G.; LAWLER, Edward E. Built to change organizations and responsible progress: Twin pillars of sustainable success. In: Research in organizational change and development. Emerald Group Publishing Limited, 2010. p. 1-49.

YAMMARINO, F. J.; SALAS; E., SERBAN, A.; SHIRREFFS, K.; \& SHUFFLER, M. L. Collectivistic leadership approaches: Putting the "we" in leadership science and practice. Industrial and Organizational Psychology, v. 5, n. 4, p. 382-402, 2012.

YAMMARINO, Francis J.; BASS, Bernard M. Transformational leadership and multiple levels of analysis. Human relations, v. 43, n. 10, p. 975-995, 1990. 
YUKL, Gary. An evaluation of conceptual weaknesses in transformational and charismatic leadership theories. The leadership quarterly, v. 10, n. 2, p. 285305, 1999.

YUKL, Gary. Leading organizational learning: Reflections on theory and research. The Leadership Quarterly, v. 20, n. 1, p. 49-53, 2009.

YUKL, Gary; FU, Ping Ping. Determinants of delegation and consultation by managers. Journal of Organizational Behavior: The International Journal of Industrial, Occupational and Organizational Psychology and Behavior, v. 20, n. 2, p. 219-232, 1999.

ZACCARO, S. J. Executive leadership: An introduction. The Nature of Executive Leadership: A Conceptual and Empirical Analysis of Success, p. 319, 2001.

ZAHRA, Shaker A.; SAPIENZA, Harry J.; DAVIDSSON, Per. Entrepreneurship and dynamic capabilities: A review, model and research agenda. Journal of Management studies, v. 43, n. 4, p. 917-955, 2006.

ZALEZNIK, Abraham. Managers and leaders: Are they different. 1977.

ZHANG, Xiaomeng; BARTOL, Kathryn M. Linking empowering leadership and employee creativity: The influence of psychological empowerment, intrinsic motivation, and creative process engagement. Academy of Management Journal, v. 53, n. 1, p. 107-128, 2010.

ZOLLO, M.; WINTER, S. G. Deliberate learning and the evolution of dynamic capabilities. Organization Science, v. 13, n. 3, p. 339-351, 2002.

ZOTT, Christoph. Dynamic capabilities and the emergence of intraindustry differential firm performance: insights from a simulation study. Strategic $\begin{array}{llllllll}\text { management journal, } & \text { v. } 24, \quad \text { n. } 2, & \text { p. } & 97-125, & \end{array}$ 


\section{Apêndice A \\ Questionário 01 (Líderes)}
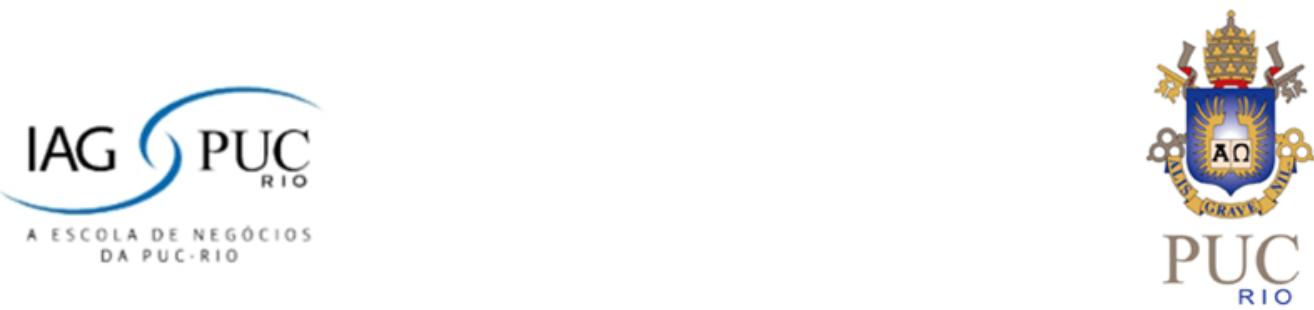

Esta pesquisa faz parte de um estudo acadêmico e tem por objetivo fazer um levantamento sobre equipes de projeto. Para isso, solicitamos que você responda a algumas questões sobre as equipes de projeto que liderou. Ressaltamos que para serem gerados resultados válidos, é fundamental que você tente retratar a realidade da equipe de forma exata e sincera. As suas respostas são confidenciais e anônimas. Apenas o pesquisador terá acesso às suas respostas. Para iniciar agora a pesquisa pressione a seta abaixo. Em caso de dúvida, você pode entrar em contato no email abaxo.

Obrigado!

Felipe Esteves

Doutorando em Administração de Empresas IAG-PUC Rio esteves.lipe@gmail.com

Selecione na lista abaixo o projeto que você liderou (ou lidera atualmente). Caso você tenha liderado mais de uma equipe de projeto, solicitamos que primeiro responda o questionário para projetos já concluídos. Depois disso, você deve voltar ao início do questionário e responder sobre o projeto mais recente ou atual.

$\boldsymbol{\nabla}$ LISTA DE PROJETOS

Neste questionário você encontrará uma série de frases e deverá verificar em que medida elas se aplicam à equipe de projeto indicada. 
1. Os itens abaixo dizem respeito às capacidades da equipe em comparação com outras equipes de projeto com a mesma finalidade. Para cada um dos itens marque a opção que julgar mais adequada.

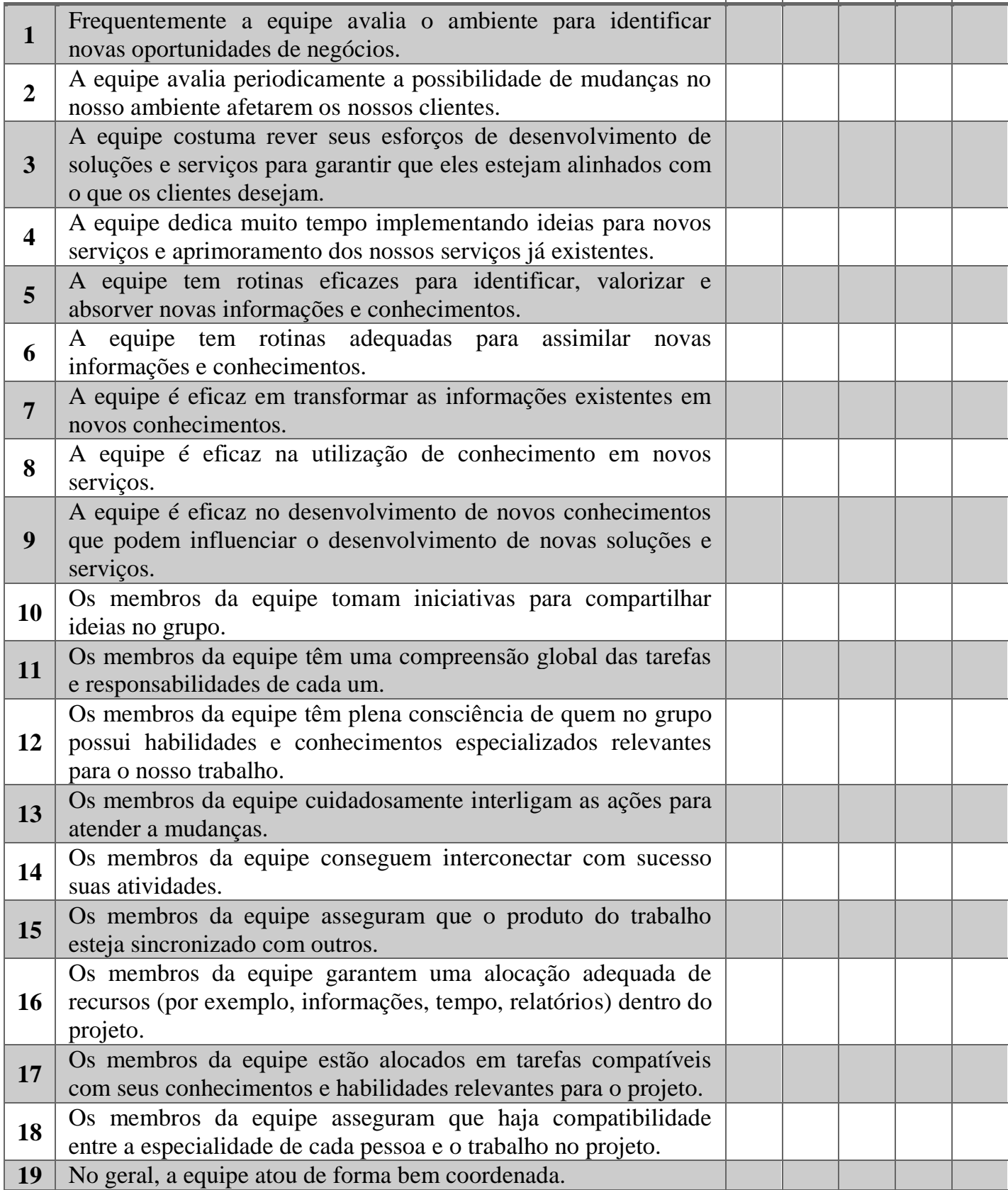


Outras informações

2. Sexo:

Masculino

Feminino

3. Por favor, preencha os campos com as informações abaixo.

Idade (anos):

Tempo de experiência profissional (anos):

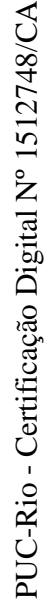

Tempo de experiência como gestor ou líder (anos):

Tempo que você trabalha na empresa (anos):

4. Qual o seu grau de instrução?

$\boldsymbol{\nabla}$ LISTA DE OPÇÕES 


\section{Apêndice B \\ Questionário 02 (Subordinados/Seguidores)}
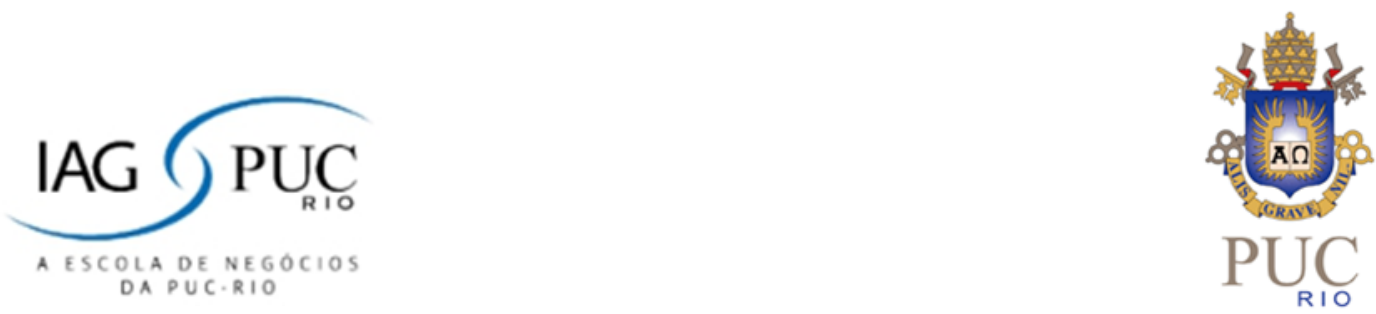

Esta pesquisa faz parte de um estudo acadêmico e tem por objetivo fazer um levantamento sobre equipes de projeto. Para isso, solicitamos que você responda a algumas questões sobre as equipes de projeto das quais participou. Ressaltamos que para serem gerados resultados válidos, é fundamental que você tente retratar a realidade da equipe de forma exata e sincera. As suas respostas são confidenciais e anônimas. Apenas o pesquisador terá acesso às suas respostas. Para iniciar agora a pesquisa pressione a seta abaixo. Em caso de dúvida, você pode entrar em contato no email abaixo.

Obrigado!

Felipe Esteves

Doutorando em Administração de Empresas IAG-PUC Rio

esteves.lipe@gmail.com

Selecione na lista abaixo o projeto do qual participou (ou participa atualmente). Caso você tenha atuado em mais de uma equipe de projeto, solicitamos que primeiro responda o questionário para projetos já concluídos. Depois disso, você deve voltar ao início do questionário e responder sobre o projeto mais recente ou atual.

\section{LISTA DE PROJETOS}

Neste questionário você encontrará uma série de frases e deverá verificar em que medida elas se aplicam ao líder do projeto indicado. 
1. Pense no seu superior imediato no projeto. Indique até que ponto as frases abaixo descrevem o comportamento dele(a) no dia a dia e na relação com seus liderados de forma precisa. Até que ponto esse líder se comporta de forma idealista e inspiradora, motivando seus liderados a se esforçarem para alcançar metas desafiadoras? O líder desse projeto...

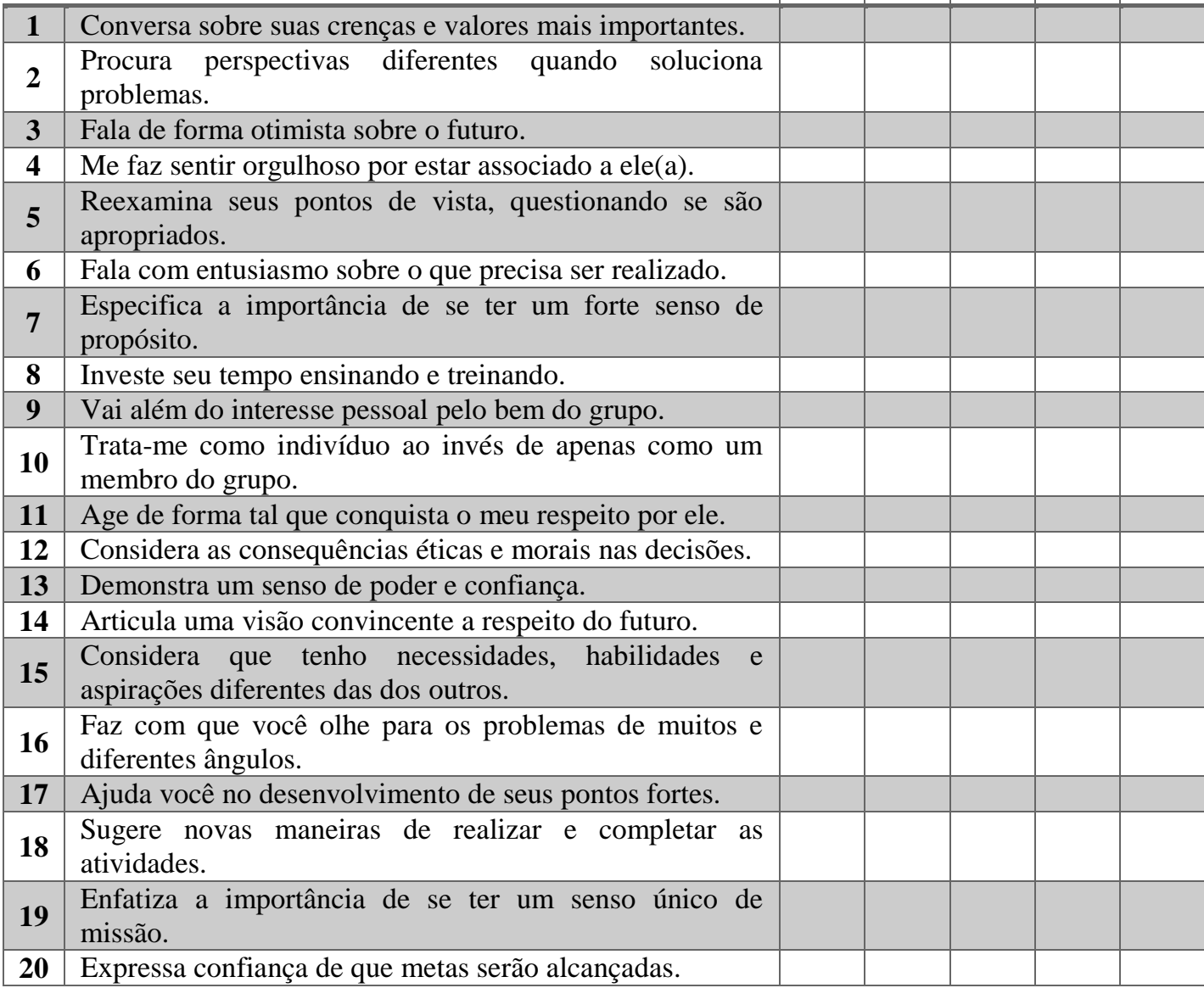


2. Até que ponto esse líder faz com que a equipe/organização se adapte ao ambiente externo e use seus recursos eficientemente? O líder desse projeto...

\begin{tabular}{|c|c|c|c|c|c|c|}
\hline & & 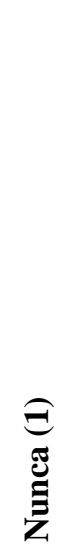 & 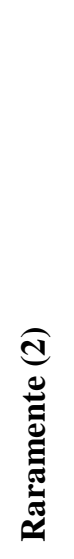 & 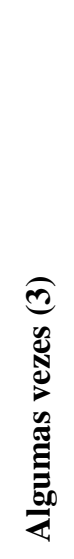 & 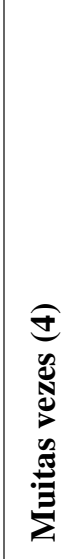 & 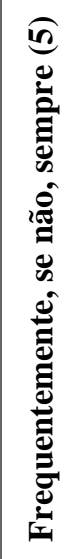 \\
\hline 1 & Compreende as restrições da nossa equipe/organização. & & & & & \\
\hline 2 & $\begin{array}{l}\begin{array}{l}\text { Sente o que precisa } \\
\text { equipe/organização. }\end{array}\end{array}$ & & & & & \\
\hline 3 & $\begin{array}{l}\text { Garante que sua visão seja entendida em termos } \\
\text { específicos. }\end{array}$ & & & & & \\
\hline 4 & Traduz a missão em objetivos específicos. & & & & & \\
\hline 5 & Remove obstáculos à minha realização de objetivos. & & & & & \\
\hline 6 & $\begin{array}{l}\text { Garante que eu tenha recursos suficientes para alcançar } \\
\text { meus objetivos. }\end{array}$ & & & & & \\
\hline 7 & Me ajuda a aprender com meus erros. & & & & & \\
\hline 8 & Me fornece um feedback construtivo sobre meus erros. & & & & & \\
\hline
\end{tabular}


3. Até que ponto esse líder compartilha sua autoridade, dando mais responsabilidade e autonomia para os membros da equipe? O líder desse projeto...

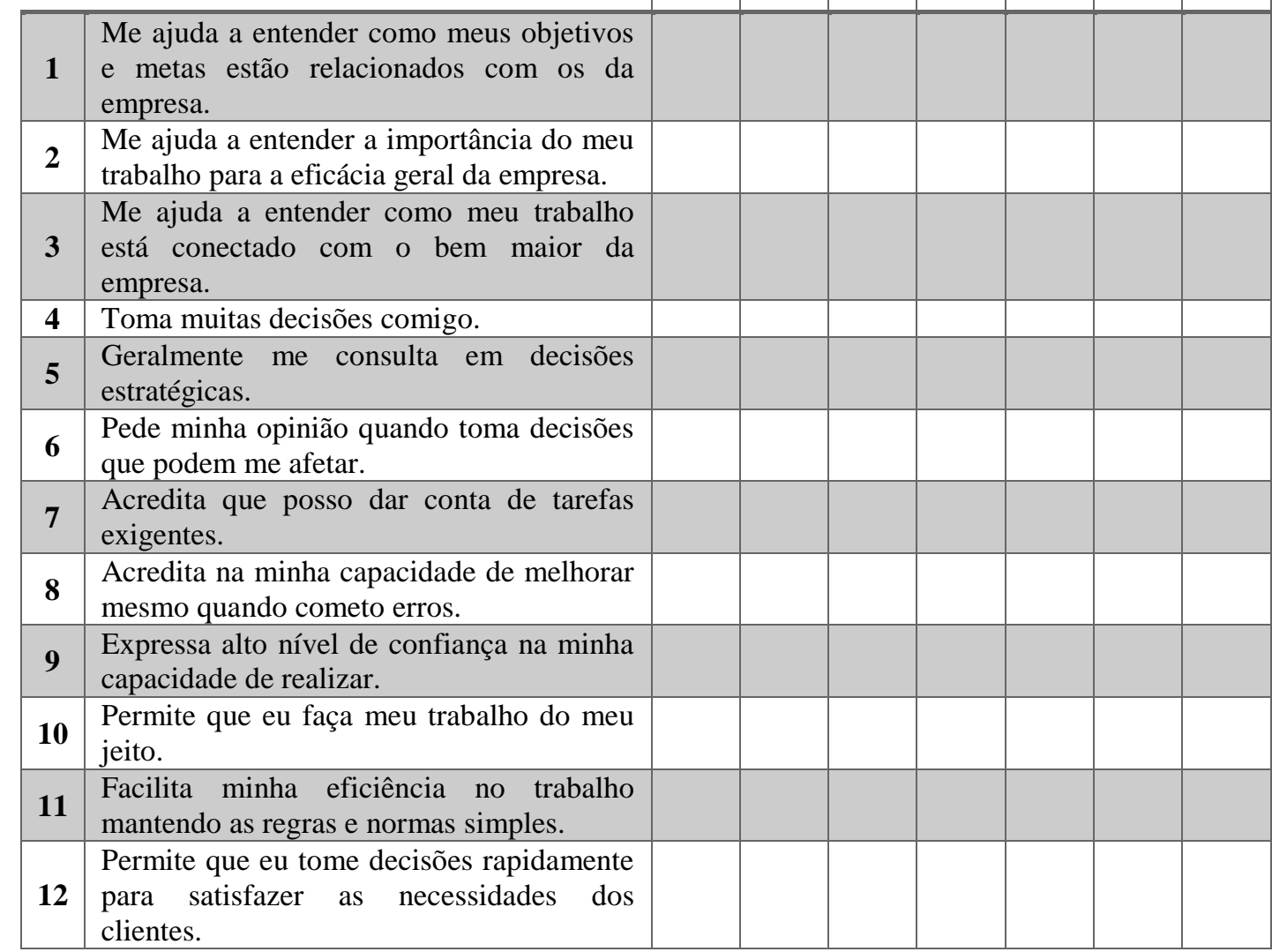


4. Até que ponto esse líder recompensa a equipe pelos seus esforços? O líder desse projeto...

\begin{tabular}{|c|c|c|c|c|c|c|}
\hline & & 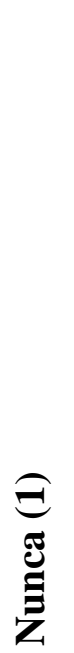 & 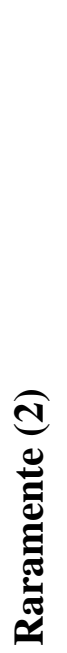 & 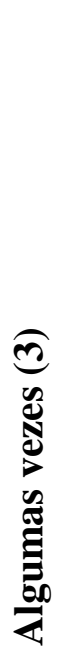 & 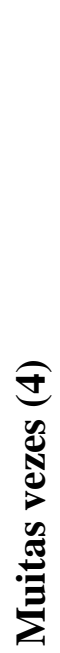 & 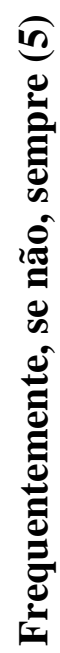 \\
\hline 1 & Dá assistência em troca de seus esforços. & & & & & \\
\hline 2 & $\begin{array}{l}\text { Discute quem é o responsável por atingir } \\
\text { metas específicas. }\end{array}$ & & & & & \\
\hline 3 & $\begin{array}{l}\text { Deixa claro o que cada um pode esperar } \\
\text { receber quando as metas são alcançadas. }\end{array}$ & & & & & \\
\hline 4 & $\begin{array}{l}\text { Expressa satisfação quando você } \\
\text { corresponde às expectativas. }\end{array}$ & & & & & \\
\hline
\end{tabular}


Outras informações

5. Sexo:

Masculino

Feminino

6. Por favor, preencha os campos com as informações abaixo.

Idade (anos):

Tempo de experiência profissional (anos):

Tempo que você trabalha na empresa (anos):

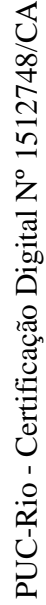

Tempo que você trabalha com este chefe ou líder (anos):

7. Qual o seu grau de instrução?

$\boldsymbol{\nabla}$ LISTA DE OPÇÕES 